\title{
Qualitätsentwicklung einer außerschulischen Biodiversitätsbildung
}

Ein Beitrag zur formativen Evaluation von Bildungsmaßnahmen

Dissertation zur Erlangung des philosophischen Doktorgrades

an der Philosophischen Fakultät der Georg-August-Universität Göttingen

\author{
vorgelegt von \\ Silvia Schönfelder \\ aus Falkenstein / Harz
}

Göttingen 2009 
1. Gutachterin: Prof. Dr. Susanne Bögeholz

2. Gutachterin: Prof. Dr. Carola Surkamp

3. Gutachter: Prof. Dr. Michael Sauer

Tag der mündlichen Prüfung: 26.05.2009

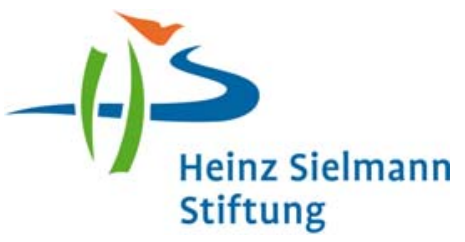

Gefördert durch die Heinz Sielmann Stiftung. 


\section{Inhaltsverzeichnis}

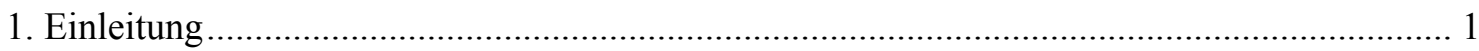

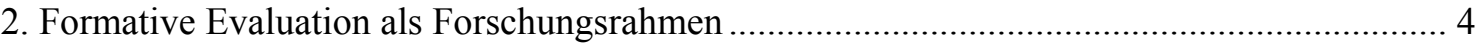

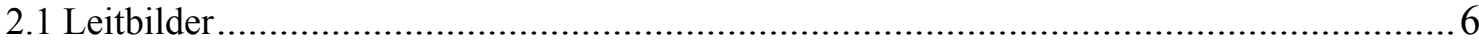

2.1.1 Anforderungen an das Leitbild zur Biodiversitätsbildung der Heinz Sielmann Stiftung.... 9

2.2 Einfluss subjektiver Einschätzungen auf eine leitbildbasierte Bildungsarbeit - Theory of Planned Behavior

3. Forschungsfragen 16

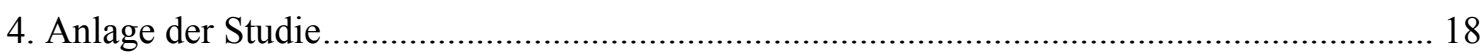

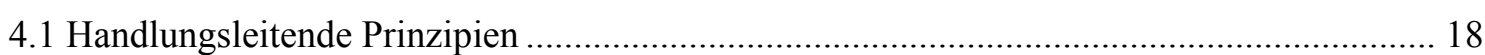

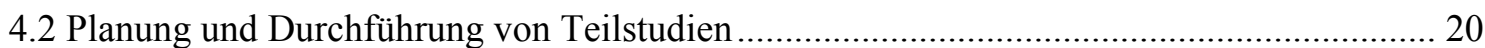

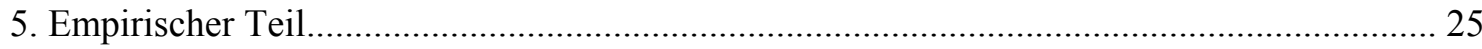

5.1 Teilstudie 1: Extra-Curricular biodiversity education: Educational goals for an education centre in Lower Saxony

5.2 Teilstudie 2: Subjektive Einschätzungen von Umweltbildner(inne)n in Bezug auf ihr neues Leitbild zur Biodiversitätsbildung - Ein Beitrag zur formativen Evaluation

5.3 Teilstudie 3: Bewertungskompetenz in der reflexiven Leitbildarbeit eines Umweltbildungszentrums - Ein Beitrag zur Professionalisierung des pädagogischen Personals

Anhang.

I. Aufbereitungs- und Auswertungsleitfaden für problemzentrierte Einzelinterviews und

Fokusgruppen

II. Datennachweis 


\section{Tabellenverzeichnis}

Tabelle 1. Teilkompetenzen von Gestaltungskompetenz.................................10

Tabelle 2. Aufbau eines wissenschaftlichen Fundaments................................22

Table 3. Excerpt from the interview guide - example of Sustainable Development..............30

Table 4. Focus Shift of Ecology Education to Leitbild-based biodiversity education.............31

Table 5. Core content Leitbild goals, sub-goals and quality criteria..........................34

Table 6. Tool-like Leitbild goals, sub-goals and quality criteria............................36

Table 7. Cross-linking Leitbild goals, sub-goals and quality criteria.........................38

Table 8. Leitbild-based courses and course-specific quality criteria (c-s qc) ..................39

Table 9. Achievement of course-specific quality criteria in course performances...............41

Tabelle 10. Auszug aus dem Leitbild der Biodiversitätsbildung der Heinz Sielmann Stiftung

- Beispiel Nachhaltige Entwicklung...................................................54

Tabelle 11. Auszug aus dem verwendeten Interviewleitfaden, in Anlehnung an

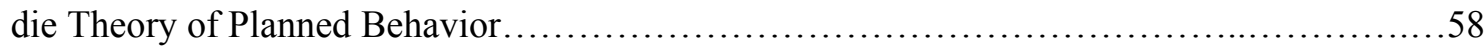

Tabelle 12. Systematisches Bewerten - Zielbereich des Leitbildes zur Biodiversitätsbildung

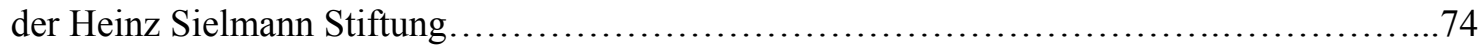

Tabelle 13. Verlaufsplan zur Veranstaltung Kulturlandschaft und angesprochene

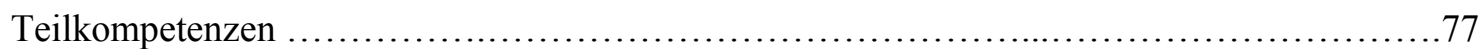

Tabelle 14. Ausschnitt aus dem Interviewleitfaden zum Fokusgruppengespräch

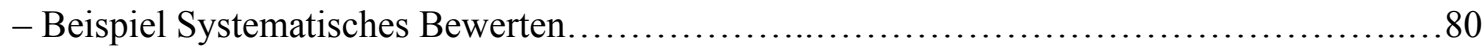




\section{Abbildungsverzeichnis}

Abbildung 1. Evaluationszyklus.

Abbildung 2. Theory of Planned Behavior, spezifiziert für eine formative Evaluation leitbildbezogener Biodiversitätsbildung.

Abbildung 3. Anlage der Studie zur formativen Evaluation der Biodiversitätsbildung in der Heinz Sielmann Stiftung. ..

Figure 4. Heinz Sielmann Stiftung guidelines for environmental education .28

Figure 5. Study design. .32

Figure 6. The goals addressed by the Leitbild-based courses- I Agriculture and

Cultivated Landscapes, II Settlement Areas, III Landscape Conservation and

IV Natural Succession

Abbildung 7. Theory of Planned Behavior

Abbildung 8. Kontinuierliche Leitbildarbeit zur Verstetigung einer formativen Evaluation......73

Abbildung 9. Ausschnitt aus dem Kategoriensystem: Kategorien zum Leitbildziel

Systematisches Bewerten....

Abbildung 10. Mögliche Umsetzung der Veranstaltung Kulturlandschaft in Zusammenarbeit von Schule und außerschulischem Lernort

Abbildung 11. Kontinuierliche Leitbildarbeit, erfahrungsbasiert modifiziert.

Abbildung 12. Transkriptionsregeln 116

Box 1. Handlungsempfehlung zur Förderung einer positiven Einstellung der Umweltbildner(innen).

Box 2. Handlungsempfehlung zur Förderung der subjektiven Norm bei Umweltbildner(inne)n

Box 3. Handlungsempfehlungen zur Erhöhung wahrgenommener eigener Kompetenzen bei Umweltbildner(inne)n.

Box 4. Handlungsempfehlungen zur Verhaltenserleichterung von Bedingungen, die nicht der direkten Kontrolle der Umweltbilder(innen) unterliegen

Box 5. Szenario zur Veranstaltung Kulturlandschaft. 



\section{Einleitung}

Umweltbildungszentren als außerschulische Lernorte können dazu beitragen, Schule zu öffnen und damit Schulunterricht sinnvoll zu ergänzen (vgl. Eschenhagen, Kattmann \& Rodi, 2008). Ihre Lernangebote ermöglichen Schüler(inne)n, Natur direkt und umfassend zu erfahren sowie praktische Maßnahmen zum Schutz und zur Nachhaltigen Nutzung von Biodiversität kennen zu lernen. Klassischerweise bieten Umweltbildungszentren Bildungsmaßnahmen u. a. zur Struktur und Funktion von Ökosystemen, zur Vielfalt und ökologischen Funktion von Arten sowie zur Entwicklung von Lebewesen an (vgl. Bolscho \& Hauenschild, 2006). Eine besondere Form von Umweltbildungszentren stellen Regionale Umweltbildungszentren (RUZ; Niedersächsisches Kultusministerium, 2006) dar. Diese Lernorte sind spezifisch für das Bundesland Niedersachsen. Sie werden vom Kultusministerium ernannt und verpflichten sich mit der Ernennung zum einen dazu, Schulunterricht kompetenzorientiert $^{1} \quad \mathrm{zu}$ unterstützen (Kultusministerkonferenz (KMK), 2005; Niedersächsisches Kultusministerium 2007, 2008). Sie sind zum anderen dazu aufgefordert, Bildung für eine Nachhaltige Entwicklung (Deutsche UNESCOKommission e.V. / Nationalkomitee UN-Dekade „Bildung für Nachhaltige Entwicklung“, 2008) zu fördern (Bundesministerium für Bildung und Forschung (BMBF), 2002; Niedersächsisches Kultusministerium, 2006).

Die Heinz Sielmann Stiftung mit ihrem Hauptsitz in Duderstadt bei Göttingen ist seit 2004 ein Regionales Umweltbildungszentrum. Ihr Naturerlebniszentrum besteht bereits seit 1996 mit einem klassischen Umweltbildungsangebot. Mit der Ernennung zum Regionalen Umweltbildungszentrum ist die Heinz Sielmann Stiftung aufgefordert, ihr Bildungsangebot kompetenzorientiert zu ergänzen und somit die schulische Vermittlung curricular valider Kompetenzen (KMK, 2005; Niedersächsisches Kultusministerium, 2007, 2008) sowie von Bildung für Nachhaltige Entwicklung (Deutsche UNESCOKommission e.V. / Nationalkomitee UN-Dekade „Bildung für Nachhaltige Entwicklung“, 2008) zu unterstützen (BMBF, 2002; Niedersächsisches Kultusministerium, 2006). Um diesen Herausforderungen gerecht zu werden, wurde in Anlehnung an die

Kompetenzen sind definiert als individuelle kognitive Fähigkeiten und Fertigkeiten, die für ein erfolgreiches und verantwortungsvolles Handeln in Problemlösesituationen notwendig sind sowie damit verbundene motivationale, volitionale und soziale Parameter (Weinert, 2001). 
symbiotische Implementationsstrategie nach Gräsel und Parchmann (2004) in Zusammenarbeit von Biologiedidaktiker(inne)n und Umweltbildner(inne)n ein innovatives Bildungsangebot forschungsbasiert erarbeitet und im Rahmen einer formativen Evaluation wissenschaftlich begleitet. Die Arbeitsgruppe legte zunächst ein Leitbild (Giesel, 2007) für neue Bildungsmaßnahmen fest. Entsprechend dem Anliegen Heinz Sielmanns ${ }^{2}$ fokussiert das Leitbild insbesondere auf eine Bildung zum Schutz und zur Nachhaltigen Nutzung von Biodiversität ${ }^{3}$ (Convention on Biological Diversity (CBD), 1992; BMBF, 2006; Lindemann-Matthies, Constantinou, Junge, Köhler, Mayer, Nagel, Raper, Schüler \& Kadji-Beltran, 2009; Bögeholz, Stelte \& Säger, 2005). Das Leitbild basiert auf einem gemeinsam mit den Umweltbildner(inne)n erarbeiteten wissenschaftlichen Fundament. Es bildet die Grundlage für vier Veranstaltungen, die in Form von Modulen für die Sekundarstufe I (7./8. Klasse) entwickelt, erprobt, evaluiert und optimiert wurden.

Eine formative Evaluation wurde eingesetzt, um prozessbegleitend Informationen über die Qualität der Leitbildarbeit zu gewinnen und diese für Optimierungsmaßnahmen zu nutzen (Kempfert \& Rolff, 2005; Burkhard \& Eikenbusch, 2000). Für einen möglichst umfassenden Einblick (Flick, 2008) wurden drei qualitative Teilstudien durchgeführt. In Teilstudie 1 wurde basierend auf einem wissenschaftlichen Fundament eine Fokusgruppe (Morgan, 1997; Bryman, 2004) eingesetzt, um das neue Leitbild sowohl forschungsbasiert als auch praxisrelevant (vgl. Gräsel \& Parchmann, 2004) festzulegen. Nicht-teilnehmende Beobachtungen (Diekmann, 2007; Bortz \& Döring, 2006) dienten anschließend dazu, Umsetzungen des Leitbildes in Veranstaltungen zu beurteilen. In einer zweiten Teilstudie wurden die subjektiven Einschätzungen der Umweltbildner(innen) als Voraussetzung für eine qualitativ hochwertige Leitbildarbeit (Helmke, 2009) untersucht. Hierfür wurden problemzentrierte Einzelinterviews (Mayring, 2002) eingesetzt. Teilstudie 3 stellt damit einen ersten Beitrag einer kontinuierlichen Qualitätsentwicklung der leitbildbasierten Biodiversitätsbildung in der Heinz Sielmann Stiftung dar (vgl. Kempfert \& Rolff, 2005; Burkhard \& Eikenbusch, 2000). Eine zweite Fokusgruppe (Morgan, 1997; Bryman, 2004) diente dazu, das

\footnotetext{
Heinz Sielmann (1917-2006) wurde durch seine Naturfilme und seinen Einsatz für den Naturschutz bekannt. Gemeinsam mit seiner Frau, Inge Sielmann, gründete er 1994 die Heinz Sielmann Stiftung, die Naturschutz- wie auch Umweltbildungsprojekte fördert.

Biodiversität umfasst sowohl die Vielfalt der Arten als auch die genetische und ökosystemare Vielfalt (vgl. Townsend, Harper \& Begon, 2003).
} 
Leitbild sowie erste Veranstaltungen nach dem Leitbild erfahrungsbasiert zu reflektieren und Hinweise für Optimierungsarbeiten zu identifizieren. Dabei wurde insbesondere eine Vermittlung von Bewertungskompetenz (Eggert \& Bögeholz, 2006; Bögeholz, 2007) als neue und zentrale Herausforderung in der Bildungspraxis der Heinz Sielmann Stiftung in den Blick genommen.

In den folgenden Kapiteln wird zunächst die theoretische Grundlage der Evaluationsstudie dargestellt (Kapitel 2). Forschungsfragen werden aufgezeigt (Kapitel 3) und die methodische Vorgehensweise wird erläutert (Kapitel 4). Im fünften Kapitel werden die durchgeführten Teilstudien umfassend vorgestellt und anschließend im sechsten Kapitel zusammengefasst und diskutiert. 


\section{Formative Evaluation als Forschungsrahmen}

Die Studie stellt einen Beitrag zur formativen Evaluation außerschulischer Bildungsangebote dar. Als Evaluation wird eine systematische Sammlung, Analyse und Bewertung von Informationen über Bildungsangebote bezeichnet. Sie dient dazu, Erkenntnisse über die Qualität von Maßnahmen zu gewinnen, Entscheidungen für Optimierungsarbeiten zu treffen und somit die Gestaltung von Bildungsmaßnahmen zielgerichtet $\mathrm{zu}$ planen und $\mathrm{zu}$ steuern. Eine Evaluation ist damit ein zentrales Instrument der Qualitätsentwicklung, Qualitätssicherung und Rechenschaftslegung (Helmke, 2009; Kempfert \& Rolff, 2005; Burkhard \& Eikenbusch, 2000).

Evaluationen weisen ein zyklisches Vorgehen (Abbildung 1) auf.

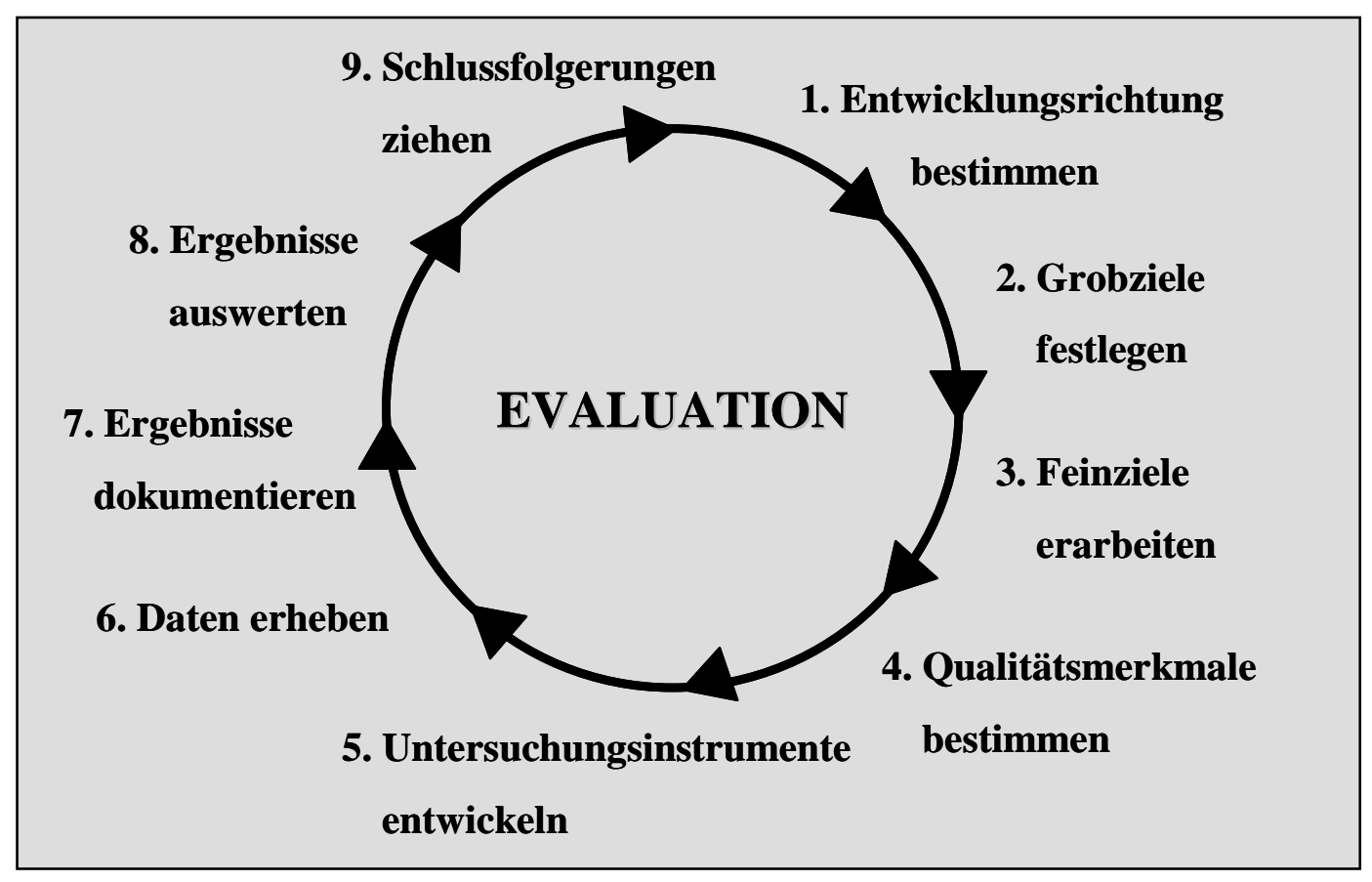

Abbildung 1. Evaluationszyklus (verändert nach Schratz, 2003)

Um eine gewählte Entwicklungsrichtung (z.B. von Bildungsmaßnahmen) zu fördern, sind Ziele festzulegen, die für die Entwicklung und Umsetzung von Bildungsmaßnahmen handlungsleitend sein sollen (z.B. Kuckartz, Dresing, Rädiker \& Stefer, 2008). Dabei werden zunächst Grobziele definiert, die dann in Feinziele ausdifferenziert werden. Festgelegte Ziele sollten generell erreichbar sein. Um 
überprüfen zu können, inwieweit Ziele erfüllt werden, müssen Qualitätsmerkmale erstellt werden. Qualitätsmerkmale werden von festgelegten Zielsetzungen abgeleitet und anhand geeigneter Forschungsinstrumente untersucht. Dafür müssen sie messbar sein. Gewählte Untersuchungsmethoden sowie die Zeitpunkte der Erhebung(en) sollten dabei dem Untersuchungsgegenstand angemessen sein. Erhobene Daten werden aufbereitet und ausgewertet, um schließlich Schlussfolgerungen für Optimierungen von Zielerreichungen ziehen zu können. Anschließend kann der Evaluationsprozess erneut durchgeführt werden (vgl. Schratz, 2003; Burkhard \& Eikenbusch, 2000).

Die Gestaltung eines Evaluationsprozesses ist Teil einer sozialen Interaktion. Evaluationsergebnisse sind den Beteiligten in Feedbackgesprächen (und formalen Berichten) vorzustellen und mit ihnen zu diskutieren, um Konsequenzen für das weitere Handeln vereinbaren zu können (Kuckartz et al., 2008). Feedbackgespräche sind sensible Situationen, da sowohl Evaluierte ihr Verhalten als auch durch sie erzielte Ergebnisse beurteilt werden. Um Akzeptanzproblemen zu begegnen, ist ein behutsames Vorgehen notwendig. Zusätzlich müssen Feedbackgespräche auf (möglichst) objektiven Daten beruhen und zielorientiert geplant und durchgeführt werden (Kempfert \& Rolff, 2005).

Evaluationen sind theoretisch innerhalb von zwei Dimensionen unterscheidbar: zum einen mit Blick auf die evaluierende(n) Person(en) und zum anderen auf den Zweck, der mit einer Evaluation verbunden ist. In Bezug auf die Durchführenden einer Evaluation werden interne von externen Evaluationen unterschieden. Interne Evaluationen werden von den Mitarbeiter(inne)n einer Einrichtung selbst durchgeführt. Dabei sind sowohl Selbstevaluationen als Evaluationen innerhalb des Kollegiums denkbar. Externe Evaluationen werden von einrichtungsfremden Personen durchgeführt. Vorteile externer Evaluationen können u. a. eine erhöhte Objektivität von Evaluationsergebnissen, eine größere Glaubwürdigkeit durch expert power sowie eine Verstärkung der Kommunikation über Evaluationsergebnisse sein. Die Einbindung einrichtungsfremder Personen kann jedoch auch zu Akzeptanzproblemen von Evaluationsergebnissen führen, insbesondere dann, wenn kein verständnisvolles und faires Arbeitsverhältnis zwischen Evaluierten und Evaluator(in) besteht (Wottawa \& Thierau, 2003; Bortz \& Döring, 2006; Gräsel \& Parchmann, 2004).

Im Hinblick auf eine Zweckorientierung des Vorgehens werden summative von formativen Evaluationen unterschieden. Summative Evaluationen dienen dazu, die 
Ergebnisse von Maßnahmen abschließend zu bewerten. Formative Evaluationen sind hingegen zur Optimierung von Gestaltungsprozessen angelegt. Das heißt, es werden prozessbegleitend fortlaufend und umfassend Daten erhoben, ausgewertet und für Optimierungen des Prozesses genutzt. Diese Form der Evaluation erfolgt in der Regel interaktiv zwischen Evaluator(in) und Evaluierten, um handlungsrelevante Informationen direkt umsetzen zu können. Damit ist die Rolle der evaluierenden Person in der Regel abhängiger vom Gestaltungsprozess als bei summativen Herangehensweisen. Ziel formativer Evaluationen ist es, den fokussierten Prozess möglichst optimal auszugestalten, um somit die Wirksamkeit der Prozessergebnisse zu erhöhen (Wottawa \& Thierau, 2003).

Die vorliegende Evaluationsstudie wurde dazu eingesetzt, die Qualität eines außerschulischen Bildungsangebots zur Biodiversitätsbildung $\mathrm{zu}$ beurteilen und Hinweise zu identifizieren, die für eine Optimierung von Bildungsmaßnahmen genutzt werden können. Entsprechend wurde ein formativer Ansatz gewählt.

\subsection{Leitbilder}

Ein zentraler Baustein der vorliegenden Studie sind Leitbilder. Leitbilder (Giesel, 2007) stellen handlungsleitende Zielsetzungen dar. Sie sind „grundlegende zukunftsbezogene Orientierungen, die als komplexe, sozial geteilte und verinnerlichte Vorstellungen das Denken und Handeln [...] leiten" (Giesel, 2007, S. 117). Leitbilder können als Steuerungs- bzw. Planungsinstrumente sowohl für eine gesamte Einrichtung als auch für einzelne Funktionsbereiche einer Einrichtung gelten, z.B. Bildungsbereich in der Heinz Sielmann Stiftung. In Leitbildern wird bestimmt, was unter Qualität (z.B. in einer außerschulischen Biodiversitätsbildung) zu verstehen ist. Sie sind somit von grundlegender Bedeutung für Evaluationsprozesse (vgl. Kapitel 2; Giesel, 2007; Kempfert \& Rolff, 2005; Schratz, 2003).

Ein Leitbild kann verschiedene Funktionen aufweisen. Zentral sind die Orientierungs-, die Koordinations-, die Motivations- und die Identifikationsfunktion: Zum einen kann ein Leitbild die Handlungsorientierung von Akteuren erleichtern, indem Handeln richtungsweisend gelenkt wird. Durch konkrete Zielvorgaben kann die Auswahl zwischen Handlungsalternativen erleichtert und somit Handlungssicherheit erzeugt werden. Durch eine sozial geteilte Orientierung kann ein Leitbild zudem die 
Koordination und den Informationsaustausch zwischen Akteur(inn)en erleichtern. Die Handelnden lernen, sich mit den Zielen zu identifizieren. Es entsteht ein »Wir-Gefühl«, welches dazu anspornen kann, eine gemeinsame Vision zu realisieren. Das heißt, die Motivation der Handelnden kann gesteigert werden (Giesel, 2007). Neben Funktionen, die sich auf die Akteure selbst beziehen, sind weitere Leitbildfunktionen zu nennen, die sich auf das Umfeld der Handelnden beziehen. Beispielsweise kann Handeln gegenüber anderen (z.B. Vorgesetzten) legitimiert werden. Eine eindeutige Profilierung der Einrichtung kann aufgezeigt und damit verbunden, eine Abgrenzung zu ähnlichen Einrichtungen verdeutlicht werden (Giesel, 2007; Kempfert \& Rolff, 2005).

Giesel (2007) unterscheidet Leitbilder im Hinblick auf drei Dimensionen. Eine erste Dimension bezieht sich auf die Erscheinungsform eines Leitbildes. Giesel (ebd.) unterscheidet mentale (implizite) und verbalisierte bzw. manifestierte (explizierte) Leitbilder. Mentale Leitbilder können mehr oder weniger konkrete Vorstellungen fassen, die sich in ein Muster fügen und so einen sozial geteilten Bedeutungszusammenhang bilden können. Verbalisierte bzw. manifeste Leitbilder stellen hingegen eine sprachlich fixierte Form mentaler Vorstellungsmuster dar.

Eine zweite Dimension zur Differenzierung von Leitbildern bezieht sich auf die Handlungswirksamkeit. Giesel (2007) unterscheidet jene Leitbilder, die bereits zum jetzigen Zeitpunkt gelebt, also praktiziert werden von solchen, die propagiert werden, um zukünftig handlungsleitend $\mathrm{zu}$ werden. Leitbilder können somit zwischen Gegenwart und Zukunft vermitteln (Ganz \& Graf, 2007).

Inwieweit ein Leitbild handlungswirksam wird, hängt vor allem von den Vertreter(inne)n eines Leitbildes als dritte Leitbilddimension ab. Leitbilder, die von den Akteuren selbst erstellt werden, werden von Leitbildern unterschieden, die entsprechend der Erwartungen bzw. Anweisungen anderer, den Akteuren vorgegeben werden. Für die Entwicklung eines Leitbildes werden theoretisch zwei Extrem-Entwicklungsvarianten unterschieden. Beim Top-down-Verfahren wird ein Leitbild von der Unternehmensleitung hierarchisch vorgegeben. Das Prinzip ist kostengünstig und wenig zeitintensiv. Jedoch sind erhebliche Akzeptanz- und Identifikationsprobleme mit diesem Vorgehen verbunden (Giesel, 2007; Martinetz \& Köhler, 2007). Die Notwendigkeit der Beteiligung von Mitarbeiter(inne)n an der Leitbildentwicklung wird heute zunehmend hervorgehoben (Martinetz \& Köhler, 2007). Leitbilder sollten an die Vorstellungen der Mitarbeiter(innen) anschließen, denn „nur wo neu formulierte Leitbilder anschlussfähig 
sind an die bereits existierenden Vorstellungen und Wünsche, wird das neue Leitbild handlungswirksam werden können“ (Giesel, 2007, S. 98f). Im Bottom-up-Ansatz wird daher das Leitbild unter Mitwirkung aller betroffenen Akteure erarbeitet. Akzeptanzprobleme treten hierbei nur selten auf. Das Verfahren ist jedoch zeit- und kostenintensiver als eine Top-down-Strategie (Martinetz \& Köhler, 2007).

In der vorliegenden Studie werden Anforderungen an Bildungsmaßnahmen forschungsbasiert vorgegeben (vgl. Kapitel 2.1.2). Die Ausgestaltung des Leitbildes sowie leitbildbasierter Veranstaltungen erfolgt anschließend in Zusammenarbeit von Wissenschaft und Praxis. Damit liegt der Studie eine Mischform aus Top-down- und Bottom-up-Ansatz (vgl. Giesel, 2007) zugrunde.

Nach Giesel (2007) ist eine Leitbildarbeit zyklisch (im Folgenden Reflexive Leitbildarbeit genannt): Wird ein Leitbild festgelegt, bedarf es der Erprobung und Umsetzung. Eine Erfüllung des Leitbildes ist zu überprüfen. Das heißt, ein Leitbild muss anhand von Qualitätsmerkmalen gemessen werden können (Ganz \& Graf, 2007; Schratz, 2003). Neben einer Überprüfung der Umsetzung sollte das Leitbild selbst - im Sinne einer reflexionsbasierten Qualitätsentwicklung der Leitbildarbeit - kontinuierlich auf Konsistenz überprüft und gegebenenfalls weiterentwickelt werden (Giesel, 2007; vgl. auch Helmke, 2009).

Bei der Gestaltung eines Leitbilddokuments ist $\mathrm{zu}$ beachten, dass die Vorgaben umsetzbar, das heißt realisierbar sind. Unerreichbare Zielsetzungen verlieren ihre Wirksamkeit im Hinblick auf Orientierungshilfe und Mitarbeiter(innen)motivation (siehe oben; Giesel, 2007). Bei der Erstellung eines Leitbilddokuments ist weiterhin auf den Konkretisierungsgrad von Formulierungen $\mathrm{zu}$ achten. Wie konkret sollte ein Leitbild formuliert sein bzw. wie konkret muss es formuliert sein, um handlungswirksam sein zu können? Diese Frage kann nicht allgemeingültig beantwortet werden, sondern ist spezifisch für ein jedes Leitbild zu klären. Üblicherweise wird für ein Leitbild ein Leitbildkern erarbeitet, der die Hauptziele des Leitbildes beinhaltet und die damit verbundene Entwicklungsrichtung aufzeigt. Im erweiterten Leitbild wird der Leitbildkern erläutert und genauer spezifiziert. Zielsetzungen sollten einfach, anschaulich und prägnant formuliert werden. Mitarbeiter(innen) sollten sie problemlos verstehen und leicht erinnern können (Giesel, 2007; Graf \& Sprengler, 2000). 


\subsubsection{Anforderungen an das Leitbild zur Biodiversitätsbildung der Heinz Sielmann Stiftung}

Im Rahmen der vorliegenden Studie wird ein Leitbild zur Biodiversitätsbildung für die Heinz Sielmann Stiftung erstellt. Das Leitbild dient als Orientierungsrahmen (vgl. Giesel, 2007) für die Entwicklung und Umsetzung von Bildungsmaßnahmen zum Schutz und zur Nachhaltigen Nutzung von Biodiversität (CBD, 1992; BMU, 2007; BMBF, 2006). Es erweitert das bereits praktizierte Umweltbildungsprogramm der Stiftung um ein kompetenzorientiertes Bildungsangebot. Innerhalb einer Bildung für Nachhaltige Entwicklung fokussiert das Leitbild - im Sinne Heinz Sielmanns und der Heinz Sielmann Stiftung - auf eine Bildung zu Biodiversität und wirkt somit profilbildend für das Bildungsangebot der Stiftung (vgl. Giesel, 2007). Mit dem Leitbild wird festgelegt, was unter Qualität von Biodiversitätsbildung in der Heinz Sielmann Stiftung verstanden wird. Damit ist eine zentrale Grundlage für die Planung und Durchführung einer formativen Evaluation geschaffen (vgl. Kapitel 2; Kempfert \& Rolff, 2005; Schratz, 2003).

Bildungsangebote, die auf dem Leitbild basieren, haben zum Ziel, Schüler(innen) dazu zu befähigen, aktiv an der Gestaltung einer ökologisch verträglichen, wirtschaftlich leistungsfähigen und sozial gerechten Umwelt teilzunehmen (BMBF, 2002; Deutsche UNESCO-Kommission e.V. / Nationalkomitee UN-Dekade „Bildung für Nachhaltige Entwicklung“, 2008; Bundesministerium für wirtschaftliche Zusammenarbeit und Entwicklung, Kultusministerkonferenz (BMZ/KMK), 2007). Schüler(innen) sollen lernen, Wissen über Nachhaltige Entwicklung - insbesondere zum Schutz und zur Nachhaltigen Nutzung von Biodiversität - anzuwenden und Probleme nichtNachhaltiger Entwicklung zu erkennen (BMBF, 2002, 2006; Lindemann-Matthies et al., 2009). Das Ziel einer Bildung für Nachhaltige Entwicklung ist es somit, Schüler(inne)n Gestaltungskompetenz (de Haan \& Harenberg, 1999; Bormann \& de Haan, 2008) zu vermitteln. Nach de Haan, Kamp, Lerch, Martignon, Müller-Christ \& Nutzingen (2008) gliedert sich Gestaltungskompetenz in zwölf Teilkompetenzen auf (Tabelle 1). 
Tabelle 1. Teilkompetenzen von Gestaltungskompetenz (verändert nach de Haan et al., 2008)

\begin{tabular}{|c|c|c|}
\hline & KOMPETENZ... & SCHÜLER(INNEN) SOLLEN... \\
\hline 1 & zur Perspektivübernahme: & $\begin{array}{l}\text { weltoffen und neue Perspektiven integrierend Wissen } \\
\text { aufbauen. }\end{array}$ \\
\hline 2 & zur Antizipation: & $\begin{array}{l}\text { vorausschauend Entwicklungen analysieren und } \\
\text { beurteilen können. }\end{array}$ \\
\hline 3 & $\begin{array}{l}\text { zur disziplinübergreifenden } \\
\text { Erkenntnisgewinnung: }\end{array}$ & interdisziplinär Erkenntnisse gewinnen und handeln. \\
\hline 4 & $\begin{array}{l}\text { zum Umgang mit unvollständigen } \\
\text { und überkomplexen } \\
\text { Informationen: }\end{array}$ & $\begin{array}{l}\text { Risiken, Gefahren und Unsicherheiten erkennen und } \\
\text { abwägen können. }\end{array}$ \\
\hline 5 & zur Kooperation: & gemeinsam mit anderen planen und handeln können. \\
\hline 6 & $\begin{array}{l}\text { zur Bewältigung individueller } \\
\text { Entscheidungsdilemmata: }\end{array}$ & $\begin{array}{l}\text { Zielkonflikte bei der Reflexion über } \\
\text { Handlungsstrategien berücksichtigen können. }\end{array}$ \\
\hline 7 & zur Partizipation: & $\begin{array}{l}\text { an kollektiven Entscheidungsprozessen teilhaben } \\
\text { können. }\end{array}$ \\
\hline 8 & zur Motivation: & sich und andere motivieren können, aktiv zu werden. \\
\hline 9 & zur Reflexion auf Leitbilder: & $\begin{array}{l}\text { die eigenen Leitbilder und die anderer reflektieren } \\
\text { können. }\end{array}$ \\
\hline 10 & zum moralischen Handeln: & $\begin{array}{l}\text { Vorstellungen von Gerechtigkeit als Entscheidungs- } \\
\text { und Handlungsgrundlage nutzen können. }\end{array}$ \\
\hline 11 & zum eigenständigen Handeln: & selbstständig planen und handeln können. \\
\hline 12 & zur Unterstützung anderer: & Empathie für andere zeigen können. \\
\hline
\end{tabular}

Des Weiteren soll sich das Leitbild an curricularen Vorgaben, insbesondere den Kompetenzbereichen Bewertung und Erkenntnisgewinnung des Faches Biologie (KMK, 2005; Niedersächsisches Kultusministerium, 2007, 2008) orientieren. Bildungsmaßnahmen können somit dazu beitragen, Schulunterricht zu unterstützen. So sollen Schüler(innen) zum einen naturwissenschaftliche Arbeitsweisen (z.B. Hammann, 2004) kennen und systematisch anwenden lernen, um Sachinformationen zu Biodiversität, zu deren Gefährdung und zu deren Schutz generieren zu können. 
Insbesondere das Kompetenzmodell ${ }^{4}$ zum Experimentieren nach Hammann (2004) ist dabei zentral. Es umfasst drei Teilkompetenzen: 1) Suche im Hypothesen-Suchraum, 2) Suche im Experimentier-Suchraum (Planung von Experimenten) und 3) Analyse von Daten.

Zum anderen sollen Schüler(innen) lernen, systematisch zu bewerten. Sie sollen (mitunter) gleichwertige Handlungsalternativen zum Umgang mit Biodiversität systematisch miteinander vergleichen können, um tragfähige Entscheidungen zum Schutz und zur Nachhaltigen Nutzung von Biodiversität treffen zu können (Bögeholz, 2007; Eggert \& Bögeholz, 2006; BMBF, 2006). In Anlehnung an das Göttinger Modell der Bewertungskompetenz (Eggert \& Bögeholz, 2006; Bögeholz, 2007) sind vier Teilkompetenzen zentral: 1) Nachhaltige Entwicklung zu kennen und zu verstehen, 2) relevante Werte und Normen zu berücksichtigen, 3) relevante Sachinformationen zu generieren und zu reflektieren sowie 4) Handlungsoptionen miteinander zu vergleichen, auszuwählen und die Entscheidung sowie den Entscheidungsweg kritisch zu überprüfen (ebd.). Bildungsmaßnahmen zur Umsetzung von Bewertungskompetenz zu entwickeln und umzusetzen, ist eine neue, jedoch zentrale Herausforderung in der Bildungspraxis der Heinz Sielmann Stiftung. Die Bildungsarbeit zur Umsetzung von Bewertungskompetenz wird in der vorliegenden Evaluationsstudie daher besonders berücksichtigt.

Neben Vorgaben zu Bildung für eine Nachhaltige Entwicklung und curricularen Anforderungen soll sich das Leitbild an den umweltpädagogischen Leitlinien der Heinz Sielmann Stiftung (Bögeholz, Stelte \& Säger, 2005) orientieren. Die Leitlinien sind ein übergeordneter Referenzrahmen für alle Bildungsaktivitäten in der Stiftung. Mit einer ersten Leitlinie soll ein Erleben, Erkennen, Verstehen, Wertschätzen und Erhalten biologischer Vielfalt gefördert werden. Dies bedeutet „Naturschutz als positive Lebensphilosophie“ (2. Leitlinie) $\mathrm{zu}$ verstehen. Eine dritte Leitlinie umfasst das systematische Bewerten, um im Sinne Nachhaltiger Entwicklung reflektiert urteilen und entscheiden zu können. Viertens sollen reale und mediale Naturerfahrungen gefördert werden, während durch eine fünfte Leitlinie naturwissenschaftliche Arbeitsweisen 
vermittelt werden sollen. Sechstens soll die Umweltbildungsarbeit systematisch mit praktischer Naturschutzarbeit verzahnt werden.

\subsection{Einfluss subjektiver Einschätzungen auf eine leitbildbasierte Bildungsarbeit}

\section{- Theory of Planned Behavior}

Die Erprobung und Umsetzung eines erarbeiteten Leitbildes ist ein zentraler Schritt reflexiver Leitbildarbeit (vgl. Giesel, 2007). Erfahrungen in der Umsetzung können dabei die Entscheidung der Umweltbildner(innen) beeinflussen, weiterhin Veranstaltungen nach dem Leitbild zu entwickeln und umzusetzen (Ajzen, 2005, 2008; Graf, 2007; Ostermeier, Prenzel \& Duit, 2009). Darüber hinaus können mehr oder weniger bewusste subjektive Theorien (auch implizite Theorien genannt) der Umweltbildner(innen) in Bezug auf Lehren und Lernen eine Umsetzung des Leitbildes erleichtern bzw. erschweren (Helmke, 2009). Helmke (2009) gibt hierzu an: „Ein [Bildungsprogramm], das nicht den enorm starken Einfluss von impliziten Theorien [...] ausdrücklich in die Planung mit einbezieht, muss zwangsläufig scheitern - oder es wird lediglich oberflächliche Effekte haben. “ (S. 314). Um untersuchen zu können, inwieweit die Umweltbildner(innen) sich am Leitbild orientieren wollen und welche Überzeugungen eine Leitbildarbeit erleichtern bzw. erschweren, wurde im Rahmen der vorliegenden Evaluationsstudie die Theory of Planned Behavior (Ajzen, 2005, 2008; siehe Abbildung 2) eingesetzt. Die Theorie erhebt den Anspruch, Handlungen vorherzusagen und zu erklären, denen bewusste Planungsüberlegungen vorausgehen. Dabei wird ein geplantes Verhalten als „Konsequenz einer systematischen Analyse aller zur Verfügung stehenden relevanten Informationen“ (Graf, 2007, S. 35 nach Ajzen, 2005) definiert. Die Theory of Planned Behavior ist eine Erweiterung der 1975 ursprünglich von Ajzen und Fishbein entwickelten Theory of Reasoned Action (vgl. Ajzen, 2008). Die Theory of Reasoned Action geht davon aus, dass Handeln durch die Absicht, eine Handlung ausführen zu wollen, vorhergesagt werden kann. Die Absicht als bewusste Entscheidung kann als Maß dafür aufgefasst werden, wie viele Anstrengungen Umweltbildner(innen) unternehmen werden, sich am Leitbild zu orientieren (vgl. Ajzen, 2005, 2008; auch Erten, 2000). Die Theory of Reasoned Action geht weiterhin davon aus, dass eine Verhaltensabsicht durch a) die Einstellung gegenüber einem Verhalten sowie b) durch die subjektive Norm bestimmt wird (1. Theorieebene; vgl. Abbildung 2), 
denen verhaltenbeeinflussende Überzeugungen (beliefs) zugrunde liegen (2. Theorieebene; vgl. Abbildung 2).

Die Einstellung ist konzipiert als allgemeine Bewertung einer Orientierung am Leitbild. Sie beschreibt, wie positiv oder negativ die Umweltbildner(innen) einer Orientierung am Leitbild gegenüberstehen (Ajzen, 2005; vgl. auch Graf, 2007). Dabei wird die Einstellung der Umweltbildner(innen) auf einer zweiten Theorieebene von den erwarteten Konsequenzen der Leitbildarbeit (Verhaltensüberzeugungen) und einer Gewichtung der Konsequenzen (Bewertung der Verhaltensüberzeugungen) determiniert (Ajzen, 2005). Umweltbildner(innen), die eine Leitbildarbeit mit positiv gewichteten Konsequenzen verbinden, werden demnach auch eine positive Einstellung gegenüber dieser besitzen (vgl. ebd.; Frey, Stahlberg \& Gollwitzer, 2001).

Die Subjektive Norm gibt die individuelle Wahrnehmung sozialen Drucks durch wichtige Bezugspersonen an, die eine Orientierung am Leitbild befürworten oder ablehnen würden (Ajzen, 2005). Erwartungen von Personen an das Verhalten der Umweltbildner(innen) werden auf 2. Theorieebene als Normüberzeugungen bezeichnet. Die Übereinstimmungsmotivation gibt an, inwieweit die Umweltbildner(innen) bereit sind, den wahrgenommenen Erwartungen zu entsprechen (Ajzen, 2005). Je größer die Neigung der Umweltbildner(innen) ist, dem wahrgenommenen sozialen Druck Folge zu leisten, umso größer wird der Einfluss der subjektiven Norm für eine Leitbildorientierung sein (vgl. Ajzen, 2005; Frey, Stahlberg \& Gollwitzer, 2001).

Da die Theory of Reasoned Action nur dann Vorhersagen erlaubt, wenn ein Verhalten vollständig der willentlichen Kontrolle einer Person entspricht, ist ihr Geltungsbereich begrenzt. Mit der Theory of Planned Behavior wird diese Einschränkung aufgehoben. So wurde das Modell der Theory of Reasoned Action in der Theory of Planned Behavior um ein drittes Verhalten bestimmendes Konstrukt erweitert: die wahrgenommene Verhaltenskontrolle. Diese Determinante bezieht sich auf die Leichtigkeit bzw. Schwierigkeit, welche die Umweltbildner(innen) mit einer Orientierung am Leitbild verbinden. Wahrgenommene Bedingungen, die eine Orientierung am Leitbild erleichtern oder erschweren können, werden als Kontrollüberzeugungen bezeichnet. Hierzu zählen wahrgenommene Ressourcen, Fertigkeiten und eigene Verhaltensmöglichkeiten, aber auch das Verhalten anderer Personen. Die Wahrgenommene Verhaltenserleichterung/-erschwerung gibt eine Einschätzung der Umweltbildner(innen) zur Bedeutung von Kontrollüberzeugungen für 
eine Orientierung am Leitbild an (Ajzen, 2005, 2008). Je mehr Ressourcen, Fertigkeiten und Verhaltensmöglichkeiten die Umweltbildner(innen) für eine zukünftige Leitbildarbeit glauben zu besitzen, umso größer wird der Einfluss der wahrgenommenen Verhaltenkontrolle auf ihre Absicht sein, sich am Leitbild zu orientieren (vgl. Ajzen, 2005, 2008; Frey, Stahlberg \& Gollwitzer, 2001; vgl. Erten, 2000). Der Wahrgenommenen Verhaltenskontrolle wird in der Theory of Planned Behavior im Gegensatz zu Einstellung und subjektiver Norm eine besondere Rolle zugeschrieben. Es wird davon ausgegangen, dass die wahrgenommene Verhaltenskontrolle nicht nur die Absicht bestimmt. Sie kann auch - unabhängig von Absicht, Einstellung und subjektiver Norm - einen direkten Einfluss auf die Leitbildarbeit haben (Abbildung 2), z.B. dann, wenn erschwerende Bedingungen wahrgenommen werden, die sich dem Einflussbereich der handelnden Person entziehen und damit nicht lösbar erscheinen (Ajzen, 2005; Frey, Stahlberg \& Gollwitzer, 2001).

Einstellung, subjektive Norm und wahrgenommene Verhaltenskontrolle bilden zusammen ein Wirkungsgefüge auf die Absicht, ein Verhalten auszuüben (Abbildung 2). Dabei wirken sie zum einen direkt auf die Verhaltensabsicht; zum anderen beeinflussen sie sie aber auch indirekt. Zu erklären ist dies durch eine wechselseitige Beeinflussung der Konstrukte untereinander. So kann beispielsweise der wahrgenommene Besitz vieler Ressourcen, Fertigkeiten etc. für ein Verhalten dazu führen, dass eine positive Einstellung gegenüber dem Verhalten verstärkt wird. Eine Befürwortung bzw. Ablehnung eines Verhaltens durch wichtige Bezugspersonen kann dazu führen, dass eine positive bzw. negative Einstellung gegenüber dem Verhalten entwickelt wird. Eine positive Einstellung gegenüber einem Verhalten kann weiterhin dazu führen, dass wahrgenommene erschwerende Bedingungen wahrscheinlich nur einen geringen Einfluss auf die Verhaltensabsicht haben usw. (vgl. Ajzen, 2005; Frey, Stahl \& Gollwitzer, 2001). 


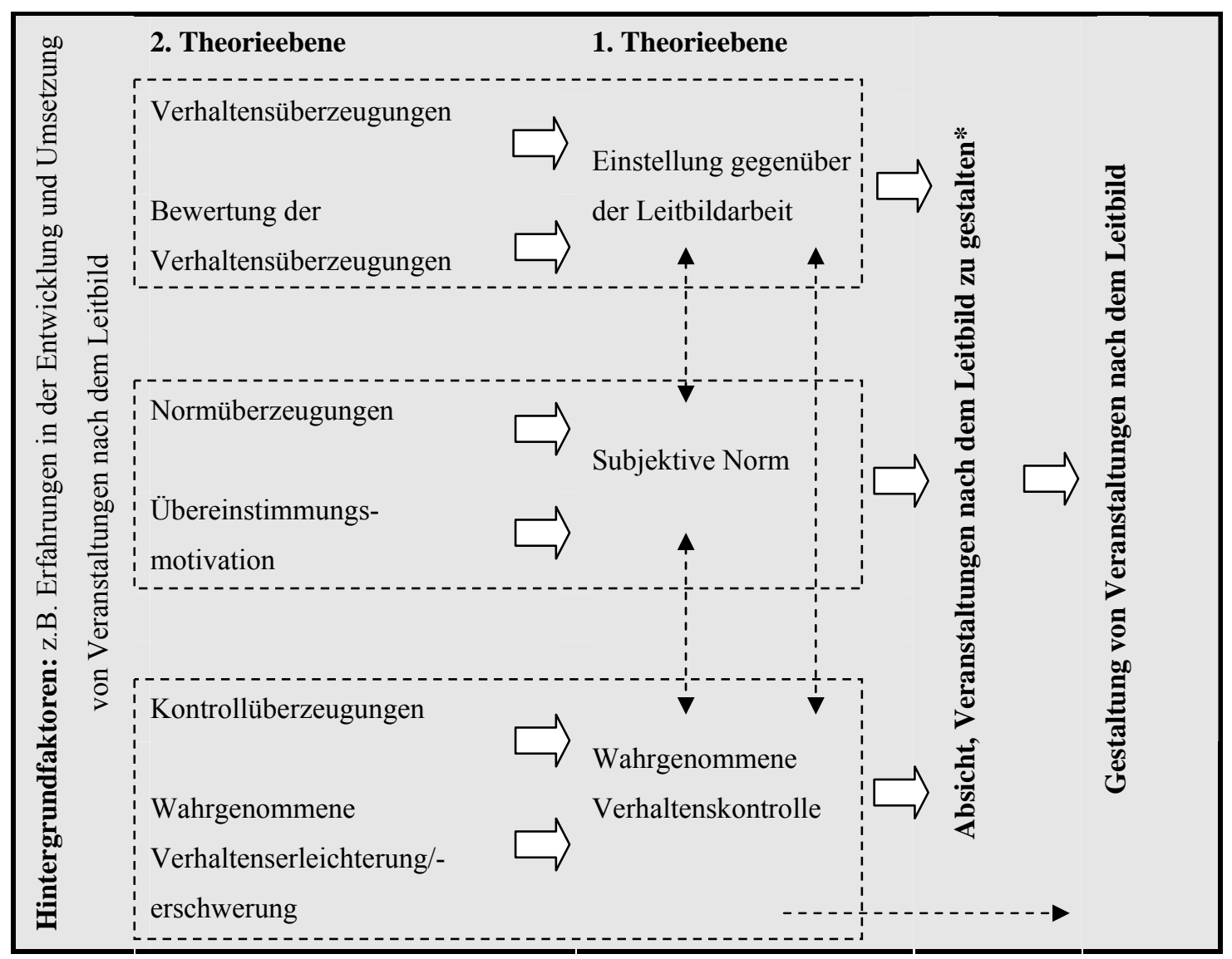

* Die Gestaltung von Bildungsveranstaltungen umfasst die Entwicklung, Umsetzung und ggf. Optimierung.

Abbildung 2. Theory of Planned Behavior, spezifiziert für eine formative Evaluation leitbildbezogener Biodiversitätsbildung (in Anlehnung an Ajzen, 2005) 


\section{Forschungsfragen}

Die vorliegende Studie dient dazu, ein innovatives forschungsbasiertes und kompetenzorientiertes Bildungsangebot zur Biodiversitätsbildung der Heinz Sielmann Stiftung formativ zu evaluieren. Im Sinne einer Qualitätsentwicklung soll dabei die Qualität des Bildungsangebots festgelegt, überprüft und optimiert werden. In Anlehnung an den aufgezeigten theoretischen Hintergrund zur formativen Evaluation (z.B. Wottawa \& Thierau, 2003), zu Leitbildern (z.B. Giesel, 2007) und subjektiven Einschätzungen (z.B. Ajzen, 2005) sollen zunächst die folgenden Fragen untersucht werden:

$>$ Woraus soll das Leitbild der Biodiversitätsbildung der Heinz Sielmann Stiftung bestehen?

o Welche Ziele und welche Teilziele soll das Leitbild beinhalten?

o Mit welchen Qualitätsmerkmalen soll eine Zielerfüllung gemessen werden?

Inwieweit wird das Leitbild in Umsetzungen von Veranstaltungen, die explizit mit Blick auf das Leitbild konzipiert wurden, reflektiert?

Inwieweit beabsichtigen die Umweltbildner(innen), Veranstaltungen nach dem Leitbild zu entwickeln und umzusetzen?

In einem weiteren Untersuchungsschritt sollen das aufgestellte Leitbild sowie leitbildbasierte Veranstaltungen - im Sinne reflexiver Leitbildarbeit - erfahrungsbasiert reflektiert werden. Es sollen Hinweise identifiziert werden, die dazu genutzt werden können, das Leitbild, Veranstaltungen nach dem Leitbild aber auch die Theorie reflexiver Leitbildarbeit weiterzuentwickeln. Dabei soll insbesondere die Vermittlung von Bewertungskompetenz (Eggert \& Bögeholz, 2006; Bögeholz, 2007) als neue, zentrale Herausforderung der Bildungspraxis der Heinz Sielmann Stiftung in den Blick genommen werden. Folgende Fragen leiteten die Untersuchung hierzu: 
Wie schätzen die Umweltbildner(innen) die leitbildbasierte Gestaltung von Bildungsmaßnahmen zur Vermittlung von Bewertungskompetenz retrospektiv ein?

$>$ Welche Hinweise geben die Umweltbildner(innen), die für eine Weiterentwicklung des Leitbildes sowie leitbildbasierter Veranstaltungen zur Vermittlung von Bewertungskompetenz genutzt werden können?

$>$ Welche Hinweise gibt die Studie im Hinblick auf eine Weiterentwicklung der Theorie zur reflexiven Leitbildarbeit? 


\section{Anlage der Studie}

Im Folgenden wird der Aufbau der Studie dargestellt. Zunächst werden Handlungsprinzipien aufgezeigt, die für die gesamte Vorgehensweise grundlegend waren. Des Weiteren wird die methodische Vorgehensweise mit dem Untersuchungsdesign vorgestellt.

\subsection{Handlungsleitende Prinzipien}

Für die vorliegende Studie zur formativen Evaluation wurden drei Handlungsprinzipien festgelegt. Zentral sollte zunächst eine enge und gleichberechtigte Zusammenarbeit zwischen Wissenschaft und Praxis in Anlehnung an Giesels (2007) Anforderungen an eine leitbildbasierte Bildungsarbeit (vgl. Kapitel 2.1) sein. Die Vorgehensweise wird als symbiotische Implementationsstrategie (Gräsel \& Parchmann, 2004; Parchmann, Gräsel, Baer, Nentwig, Demuth \& Ralle, 2006) bezeichnet. Dabei trägt (wie in Kapitel 2 ausgeführt) eine externe wissenschaftliche Begleitung dazu bei, die inhaltliche Qualität der Neugestaltung von Bildungsangeboten $\mathrm{zu}$ sichern sowie die Objektivität von Untersuchungsergebnissen zu erhöhen (vgl. Burkhard \& Eikenbusch, 2000). Eine Berücksichtigung des pädagogischen Personals fördert hingegen eine praxistaugliche Ausgestaltung eines innovativen Bildungsangebots. Zudem kann die Akzeptanz der Innovation auf Seiten der Umweltbildner(innen) erhöht werden. Letztendlich können Untersuchungsergebnisse direkt an die Betroffenen geleitet und - im Sinne einer formativen Evaluation - für gemeinsame sowohl forschungsbasierte als auch praxisrelevante Optimierungsarbeiten genutzt werden (ebd.; Gräsel \& Parchmann, 2004; Parchmann et al., 2006; Giesel, 2007). An der vorliegenden Studie waren vier Umweltbildner(innen) sowie die Referentin des Bereichs Umweltbildung der Heinz Sielmann Stiftung beteiligt. Das pädagogische Personal setzte sich hauptsächlich aus Biolog(inn)en, Förster(inne)n und Landwirt(inn)en mittleren Alters zusammen, welche bislang autodidaktisch Veranstaltungen eines klassischen Bildungsangebots entwickelten und umsetzten. Für organisatorische Absprachen wurde zudem der Stiftungsvorstand involviert. Wissenschaftlich begleitet wurde die Studie durch eine wissenschaftliche Mitarbeiterin (Autorin der Studie) sowie die Leiterin der Didaktik der Biologie, Universität Göttingen. Teilweise assistierte eine weitere wissenschaftliche 
Mitarbeiterin bei Datenerhebungen (vgl. Kapitel 5.1 und 5.3), während Examens- bzw. Masterstudierende eine Auswertung der Daten unterstützten (vgl. Kapitel 5.2 und 5.3). Weiterhin sollten in Anlehnung an die Deutsche Gesellschaft für Evaluation (DeGEval, 2005) die vier Standards zur Durchführung von Evaluationen handlungsleitend sein:

- Somit sollte das Evaluationsvorhaben ziel- und zweckorientiert eingesetzt werden. Evaluationsergebnisse sollten dem Informationsbedarf der Nutzer(innen) angemessen sein.

- Um möglichst effiziente Ergebnisse zu erzielen, sollte der Evaluationsprozess zudem systematisch geplant und ausgeführt werden.

- Weiterhin sollte die Evaluation sicherstellen, dass alle Beteiligten respektvoll und »fair« behandelt werden. Die persönlichen Rechte aller Beteiligten sollten dabei gewahrt werden.

- Abschließend sollte gewährleistet sein, dass möglichst objektive, valide und reliable Ergebnisse bereitstellt werden (vgl. auch Diekmann, 2007). Das Vorgehen und die Ergebnisse sind daher in jedem Fall kritisch zu überprüfen.

Für einen möglichst ganzheitlichen, multi-perspektivischen Untersuchungsansatz orientierte sich die Studie zudem am Prinzip der Triangulation (Flick, 2008; Denzin, 1989). Somit war für die Planung und Umsetzung der Evaluationsstudie erforderlich,

- Daten verschiedener Quellen, unterschiedlicher Messzeitpunkte, verschiedener Erhebungsorte und unterschiedlicher Personen $\mathrm{zu}$ berücksichtigen (DatenTriangulation),

- Sich dem Forschungsgegenstand durch verschiedene theoretische Grundlagen möglichst umfassend zu nähern (Theorien-Triangulation),

- Verschiedene Methoden einzusetzen, um eine Vollständigkeit zu berücksichtigender Informationen gewährleisten zu können (Methoden-Triangulation) und

- Mehrere Personen am Auswertungsverfahren erhobener Daten zu beteiligen, um subjektive Einflüsse zu reduzieren (Investigator(in)en-Triangulation). 


\subsection{Planung und Durchführung von Teilstudien}

Unter Berücksichtigung der aufgezeigten Handlungsgrundsätze wurde die vorliegende Studie zur formativen Evaluation der Biodiversitätsbildung, wie in Abbildung 3 illustriert, geplant und durchgeführt.

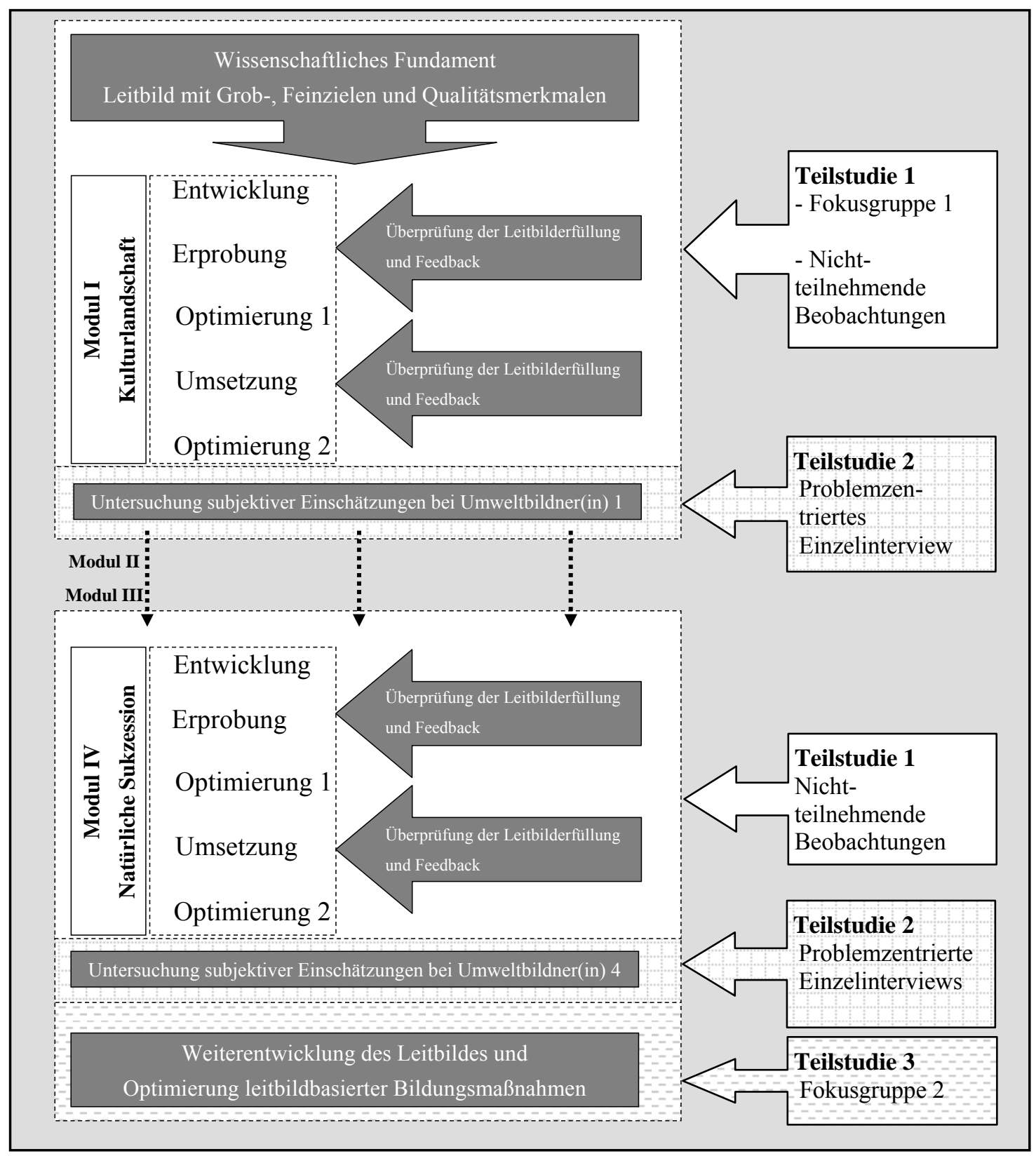

Abbildung 3. Anlage der Studie zur formativen Evaluation der Biodiversitätsbildung in der Heinz Sielmann Stiftung 
Der Gesamtstudie wurden drei qualitative Teiluntersuchungen zugrunde gelegt. Der qualitative Forschungsansatz wurde gewählt, um prozessbegleitend „wichtige Hinweise zur Beurteilung, aber auch zur Weiterentwicklung der untersuchten Maßnahmen“ (von Kardorff, 2008, S. 245) forschungsbasiert zu identifizieren, gemeinsam mit den Umweltbildner(inne)n zu diskutieren und für Optimierungsarbeiten $\mathrm{zu}$ nutzen. Im Folgenden werden die Teiluntersuchungen zunächst kurz vorgestellt und in Kapitel 5 detailliert erläutert.

Eine erste Untersuchung (Teilstudie 1; siehe Kapitel 5.1) umfasste zunächst die Erarbeitung eines forschungsbasierten Fundaments zur Biodiversitätsbildung. Hierfür wurden die Umweltbildner(innen) in insgesamt 9 halbtägigen Workshops innerhalb eines Jahres fortgebildet. Ziel war es, die Umweltbildner(innen) auf die neuen Herausforderungen für Bildungsmaßnahmen zu Biodiversität (vgl. Tabelle 2; Kapitel 2.1.1) vorzubereiten. Es sollten ihnen notwendige Kompetenzen für die Gestaltung von Bildungsangeboten vermittelt und ihnen somit ermöglicht werden, die Entwicklung des Bildungsangebotes kompetent mit zu gestalten (vgl. Ostermeier, Prenzel \& Duit, 2009; Helmke, 2009). Die Workshops wurden jeweils von bereichsspezifischen Expert(inn)en begleitet. Zudem wurde den Umweltbildner(inne)n zentrale Literatur zu den Workshops 1-9 zur Verfügung gestellt (siehe Tabelle 2).

Tabelle 2. Aufbau eines wissenschaftlichen Fundaments

\begin{tabular}{||l|l|l||}
\hline WORKSHOP & $\begin{array}{l}\text { EINBINDUNG DER } \\
\text { EXPERTISE VON: }\end{array}$ & $\begin{array}{l}\text { GRUNDLAGENLITERATUR ZUM } \\
\text { ZEITPUNKT DER WORKSHOPS } \\
\text { (2005-2006) }\end{array}$ \\
\hline \hline $\begin{array}{l}\text { 1. Nachhaltige Entwicklung und } \\
\text { Bildung für eine Nachhaltige } \\
\text { Entwicklung }\end{array}$ & $\begin{array}{l}\text { Prof. Dr. Susanne } \\
\text { Bögeholz }\end{array}$ & $\begin{array}{l}\text { Bögeholz \& Barkmann, 2005; De Haan, } \\
\text { 2005; De Haan \& Harenberg, 1999 }\end{array}$ \\
\hline \hline $\begin{array}{l}\text { 2. Sachkompetenz zu } \\
\text { Biodiversität }\end{array}$ & $\begin{array}{l}\text { Jun.-Prof. Dr. } \\
\text { Susanne Menzel }\end{array}$ & $\begin{array}{l}\text { Klein \& Ssymank, 1995; Convention on } \\
\text { Biological Diversity, 1992 }\end{array}$ \\
\hline \hline $\begin{array}{l}\text { 3. Lernvoraussetzungen zu } \\
\text { Biodiversität }\end{array}$ & $\begin{array}{l}\text { Jun.-Prof. Dr. } \\
\text { Susanne Menzel }\end{array}$ & $\begin{array}{l}\text { Retzlaff-Fürst, 2005; Bögeholz \& Rüter } \\
\text { 2004; Lindemann-Matthies, 2002 }\end{array}$ \\
\hline
\end{tabular}




\begin{tabular}{|c|c|c|}
\hline $\begin{array}{l}\text { 4. Bewerten - Grundlagen } \\
\text { Kompetenzentwicklung und } \\
\text { Bildungsstandards }\end{array}$ & $\begin{array}{l}\text { Dr. Sabina Eggert, } \\
\text { Prof. Dr. Susanne } \\
\text { Bögeholz }\end{array}$ & $\begin{array}{l}\text { Bögeholz, 2006a; Große \& Bögeholz, } \\
\text { 2005; Kultusministerkonferenz, 2005; } \\
\text { Bögeholz et al., 2004; Mayer et al. 2004; } \\
\text { Bögeholz, } 2001\end{array}$ \\
\hline $\begin{array}{l}\text { 5. Entwicklung und Umsetzung } \\
\text { von Bewertungsaufgaben }\end{array}$ & $\begin{array}{l}\text { Dr. Sabina Eggert, } \\
\text { Janin Schatz }\end{array}$ & \\
\hline $\begin{array}{l}\text { 6. Naturwissenschaftliche } \\
\text { Arbeitsweisen }\end{array}$ & Dr. Nina Holstermann & Hammann, 2005; Höttecke, 2001 \\
\hline $\begin{array}{l}\text { 7. Kompetenzmodell zum } \\
\text { Experimentieren }\end{array}$ & $\begin{array}{l}\text { Prof. Dr. Marcus } \\
\text { Hammann }\end{array}$ & Hammann, 2004 \\
\hline $\begin{array}{l}\text { 8. Sachkompetenz und } \\
\text { Lernvoraussetzungen zu } \\
\text { Wildnis }\end{array}$ & Silvia Schönfelder ${ }^{5}$ & $\begin{array}{l}\text { Schönfelder, 2005; Diemer, Held \& } \\
\text { Hofmeister, 2004; Bauer, Wasem \& } \\
\text { Hunziker, 2004; Langenhorst, 2005; } \\
\text { Scherzinger, 1997 }\end{array}$ \\
\hline $\begin{array}{l}\text { 9. Naturerfahrungen und ihre } \\
\text { Bedeutung für Umwelthandeln }\end{array}$ & $\begin{array}{l}\text { Prof. Dr. Susanne } \\
\text { Bögeholz }\end{array}$ & Bögeholz, 2006b; Bögeholz, 2005 \\
\hline
\end{tabular}

Basierend auf dem wissenschaftlichen Fundament legte die Arbeitsgruppe aus Biologiedidaktiker(inne)n und Umweltbildner(inne)n ein Leitbild (nach Giesel, 2007) mit Zielen, Teilzielen und überprüfbaren Qualitätsmerkmalen fest. Das Leitbild stellte die Grundlage für vier 6-stündige Veranstaltungen für Schulklassen der Sekundarstufe I (7./8. Klasse) dar. Die Veranstaltungen wurden in Form von prototypischen Modulen mit je einem Modul pro Jahreszeit entwickelt:

I. Kulturlandschaft (Herbst) ${ }^{6}$ : Die Veranstaltung zielt auf Biodiversität in Ökosystemen. Unterschiedlich intensiv kultivierte Ökosysteme zum Anbau von Apfelobst (Plantage, integrierter Anbau, ökologisch bedeutsame Streuobstwiese) und ihre Bedeutung für Biodiversität werden erarbeitet. Schüler(innen) bewerten anschließend die verschiedenen Anbauformen von Apfelobst unter Berücksichtigung ökologischer, ökonomischer und sozialer Aspekte.

II. Siedlungsräume (Winter): Biodiversität im Lebensraum des Menschen wird aufgezeigt. Die Gefährdung von Biodiversität in und um Wohnungen bzw. Häusern sowie

\footnotetext{
Silvia Schönfelder hat 2004 ihre Examensarbeit zur Sachkompetenz und zu Lernvoraussetzungen zu Wildnis verfasst. Eine weitere Einbindung von Expertise wurde daher im 8. Workshop nicht eingeplant. ${ }^{6}$ Die Leitbildfestlegung konnte im Frühsommer 2006 abgeschlossen werden. Entsprechend wurde eine erste Veranstaltung für eine Umsetzung im Herbst konzipiert.
} 
Maßnahmen zum Schutz von Biodiversität werden dargestellt. Schüler(innen) planen einen Siedlungsraum. Sie diskutieren, inwieweit sie Schutzmaßnahmen, wie z.B. Nistmöglichkeiten und Nahrungsquellen für Vögel und Insekten, in ihre Planung einbeziehen wollen und begründen ihre Entscheidung.

III. Landschaftspflege (Frühjahr): Schüler(innen) lernen Maßnahmen zur Landschaftspflege (häufige Mahd, seltene Mahd, keine Mahd) und ihre Bedeutung für Biodiversität kennen. Sie bewerten anschließend die verschiedenen Pflegemaßnahmen, um die Weiterentwicklung einer Parkanlage zu entscheiden.

IV. Natürliche Sukzession (Sommer): Am Beispiel des Naturschutzgebiets an der ehemaligen innerdeutschen Grenze „Grünes Band“ wird aufgezeigt, dass sich Landschaft fortwährend entwickelt. Verschiedene Sukzessionsstadien werden untersucht. Schüler(innen) diskutieren anschließend, wie die Landschaft am ehemaligen Grenzstreifen weiterentwickelt werden soll.

Jedes Modul wurde zweimal erprobt und im Hinblick auf eine Erfüllung des Leitbildes überprüft (vgl. Helmke, 2009). Die Untersuchungsergebnisse wurden den Umweltbildner(inne)n in Feedbackgesprächen (Burkhard \& Eikenbusch, 2000) vorgestellt, mit ihnen diskutiert und dazu genutzt, Umsetzungen eines Moduls gemeinsam zu optimieren (siehe Abbildung 3). Für jedes Modul wurde in Absprache mit dem pädagogischen Personal ein(e) andere(r) Umweltbildner(in) als umsetzende Person festgelegt.

In einer zweiten Teiluntersuchung (Teilstudie 2; siehe Kapitel 5.2) wurden die erfahrungsbasierten subjektiven Einschätzungen der Umweltbildner(innen) im Hinblick auf ihre Absicht (Ajzen, 2005, 2008), Veranstaltungen nach dem gemeinsam festgelegten Leitbild zu entwickeln und umzusetzen, überprüft. Die Erhebungen wurden jeweils mit einem Umweltbildner / einer Umweltbildnerin durchgeführt, der / die ein Modul dreimal umgesetzt hat. Die Untersuchungsergebnisse wurden vor allem dazu genutzt, um der Heinz Sielmann Stiftung Optimierungsvorschläge für erschwerende Bedingungen (Schratz, 2003) einer leitbildbasierten Bildungsarbeit aufzuzeigen.

Nachdem alle vier Module entwickelt und erprobt wurden, überprüfte die Arbeitsgruppe aus Wissenschaft und Praxis in einer dritten Teiluntersuchung (Teilstudie 3; siehe Kaptitel 5.3) die inhaltliche Kohärenz des Leitbildes sowie die Qualität von Leitbildveranstaltungen. Dabei gaben die Umweltbildner(innen) Hinweise an, die für eine Optimierung der Bildungsarbeit nach dem Leitbild - insbesondere zur Vermittlung 
von Bewertungskompetenz (Eggert \& Bögeholz, 2006a; Bögeholz, 2007), für eine Weiterentwicklung des Leitbildes (vgl. Giesel, 2007; Rauch, Steiner \& Streissler, 2008) sowie der Theorie zur reflexiven Leitbildarbeit (vgl. Giesel, 2007) genutzt werden können.

Ergebnisse und Schlussfolgerungen der Teilstudien 1, 2 und 3 wurden sowohl den Umweltbildner(inne)n als auch dem Vorstand der Heinz Sielmann Stiftung, dem Stiftungsrat und dem Stiftungsbeirat rückgemeldet (vgl. Kuckartz et al., 2008; Krueger \& Casey, 2000). Zum einen wurden in mehrmonatigen Abständen insgesamt acht schriftliche Berichte an die Heinz Sielmann Stiftung geleitet. Zum anderen erfolgte eine mündliche Berichterstattung im Rahmen der Sitzung des Stiftungsrats / -beirats der Heinz Sielmann Stiftung. 


\section{Empirischer Teil}

Im Folgenden werden die drei Teiluntersuchungen detailliert dargestellt. Jede Teilstudie wird zunächst durch einen Abstract zusammengefasst. Es folgen jeweils eine Teilstudien-spezifische Einleitung, eine Erläuterung des theoretischen Hintergrunds sowie ein Einblick in die gewählte methodische Vorgehensweise. Für jede Teiluntersuchung werden die gewonnenen Ergebnisse vorgestellt und anschließend diskutiert. Um das erarbeitete Leitbild sowie Ergebnisse erster Umsetzungen einer internationalen Leser(innen)schaft vorstellen $\mathrm{zu}$ können, wurde Teilstudie 1 in englischer Sprache verfasst.

\subsection{Teilstudie 1: Extra-Curricular biodiversity education: Educational goals for an education centre in Lower Saxony ${ }^{7}$}

Biodiversity education, which reflects the challenges of Education for Sustainable Development (ESD), is an innovative approach for environmental education centres in Germany. In order to develop new courses to enhance extra-curricular biodiversity education, educators and scientific fellows have developed a new Leitbild (Giesel, 2007) on learning and teaching. According to this Leitbild, which consists of goals, subgoals and quality criteria, innovative courses have been developed, tested and formatively evaluated. Results show that educators have succeeded in fulfilling quality criteria quite well. Especially, educators were successful in offering nature experiences to students. However, some deficits were detected. For instance, educators had difficulties in assisting students to connect relevant facts with norms and values in decision-making processes. This paper argues in favour of i) developing and applying a Leitbild for extra-curricular biodiversity education, and ii) observing and reflecting upon new Leitbild courses to enhance educational quality. 


\section{Introduction}

Students should be enabled to participate in shaping an ecologically sustainable, economically efficient and socially just, earth environment (i) to conserve biological diversity, and (ii) to use its components in a sustainable manner (Convention on Biological Diversity (CBD), 1992; Federal Ministry for the Environment, Nature Conservation and Nuclear Safety (BMU), 2007). Biodiversity education is a central task of German biology classroom education (Ministers of Education and Cultural Affairs of the Länder in the Federal Republic of Germany (KMK), 2005; Ministry of Education of Lower Saxony (Niedersächsisches Kultusministerium), 2007, 2008). Besides school education, extra-curricular courses play an important role in contributing to this overall educational objective. In Lower Saxony (Germany), the so-called Regionale Umweltbildungszentren (RUZ), specific environmental education centres, are charged with supporting curricular competence-oriented biodiversity education, by offering courses to school classes that meet with curricular demands. Therefore, their solely ecology-centred education concepts (Bolscho \& Hauenschild, 2006) need to be complemented by a more complex education (Lindemann-Matthies et al., 2009; Grace, 2008; Gayford, 2000): biodiversity education combines a high factual and ethical complexity of issues (Bögeholz, 2006a), which correspond to students' lives, highlight conflicts between ecological, economic and social-cultural needs, and allow students to participate actively, instead of remaining passive recipients (Lindemann-Matthies et al. 2009; Rickinson, 2001). Educational goals should contribute to achieving these aims.

A working group consisting of educators from the Heinz Sielmann Stiftung [1], a Regionales Umweltbildungszentrum, and scientific researchers from Göttingen University developed a new Leitbild (Giesel, 2007) for extra-curricular biodiversity education with educational goals and sub-goals. According to this, we defined quality criteria to assess the attainment of new goals. We developed and tested four innovative Leitbild courses for lower secondary school classes (aged 13-14). Furthermore, we evaluated the delivery of the courses formatively by observing and reflecting upon them on two separate occasions. The results of the Leitbild development as well as the course evaluation are presented and discussed in this article. 


\section{Theoretical Background}

In order to assess the quality of new biodiversity education courses, central goals and sub-goals have to be determined. These are concrete and attainable expressions of a desired educational practice, and thus constitute quality standards for educational engagement. An achievement of goals can be measured by considering quality criteria that indicate whether a goal /sub-goal is reached. Research methods consist of designing instruments for applying quality criteria. The results of such research need to be analysed in order to provide feedback that can be used to reflect upon and improve new courses and / or delivery of courses (Schratz, 2003; Seipel \& Rieker, 2003). A formative assessment guides educational development over a long period of time, and aims at assessing and improving educational practice continuously in order to increase educational effectiveness (Wottawa \& Thierau, 2003).

The development of a Leitbild for educational engagement consists of defining goals, sub-goals and quality criteria for biodiversity education. Leitbilder (Giesel, 2007) are group-specific, mental and verbalised perceptions of a desired educational practice. They help educationalists (e.g. educators in an education centre) to reach their group goals, to plan and conduct their courses precisely, to improve their performances and to increase their satisfaction with their own teaching. Thus, the most important advantage of a Leitbild is to provide orientation (Giesel, 2007), for instance in the vast educational field of Education for Sustainable Development (ESD). Further important advantages of Leitbild development are: to motivate educators to teach adequately, to foster their trust in their own educational programmes, to foster loyalty within groups and to make educational objectives more transparent (Giesel, 2007).

The newly developed Leitbild for biodiversity education primarily meets the Heinz Sielmann Stiftung educational guidelines (figure 4). The guidelines are a framework for all of the educational activities of the Heinz Sielmann Stiftung, covering all ages and groups, from kindergarten children to school classes and adults (Bögeholz, Stelte \& Säger, 2005). They constitute the broader framework of the new Leitbild, which is designed to cover education for school classes in particular. 
- Experience, understanding, appreciation and conversation of biodiversity

- Nature conservation as a positive philosophy in life

- Systematic decision making to foster an understanding of Sustainable Development

- Providing local and global nature experiences

- Knowledge of nature and scientific inquiry methods

Figure 4. Heinz Sielmann Stiftung guidelines for environmental education (Bögeholz, Stelte \& Säger, 2005)

Besides the Heinz Sielmann Stiftung guidelines, the Leitbild should build upon research referring to ESD, with the aim of reflecting upon socio-scientific issues regarding economic, ecological as well as social interests, conflicts and potential solutions (e.g. Lundegard \& Wickman, 2007; Bormann \& de Haan, 2008; Bögeholz \& Barkmann, 2005). In particular, the aim is to cover the CBD objectives (1992), such as the conservation of biological diversity, a sustainable use of its components (ecosystem diversity, species diversity and genetic diversity) and the fair and equitable sharing of the benefits arising from the utilisation of genetic resources.

In order to match school education precisely, the Leitbild should also be embedded in national and local curricular requirements. A particular focus should be on decisionmaking competence in terms of socio-scientific issues regarding biodiversity problems (cf. KMK, 2005; Harms, Mayer, Hammann, Bayrhuber \& Kattmann, 2004; Niedersächsisches Kultusministerium, 2007, 2008).

\section{Scientific Interest}

Firstly, this formative assessment study aims at developing a new Leitbild on biodiversity education for an education centre as a guideline for innovative course development. Secondly, the Leitbild is used to assess, reflect upon and optimise new courses designed according to its objectives. To these aims, the following questions are to be addressed: 
Question 1: Which goals, sub-goals and quality criteria does the new Leitbild for extracurricular biodiversity education at the Heinz Sielmann Stiftung promote?

Question 2: To what extent is the Leitbild reflected in the delivery of new courses?

\section{Methods}

The Leitbild was developed by all of the five educators of the Heinz Sielmann Stiftung and two scientific fellows. Thus, as called for by Rickinson (2006), our working group followed a symbiotic strategy (Symbiotic Implementation, Gräsel \& Parchmann, 2004, Parchmann et al., 2006): Both the researchers and the educators brought distinctive expertise to the process. While scientific mentoring achieved high-quality results, the environmental educators - biologists, agriculturists and foresters (thus, no teachers per se) - complemented scientific theory with their practical experiences of 'what works' (Parchmann et al., 2006; Gräsel \& Parchmann, 2004). It was highly important to consider the role of educators' interests. Only their support of new Leitbild made the entire process workable. Symbiotic strategies are often used when new theoretical concepts (and Leitbilder) are implemented in educational practice. For instance, the German projects Chemie im Kontext [chik] (Nentwig, Demuth, Parchmann, Gräsel \& Ralle, 2007) and Biologie im Kontext [bik] (Bayrhuber, Bögeholz, Eggert, Elster, Grube, Hößle, Linsner, Lücken, Mayer, Möller, Nerdel, Neuhaus, Prechtl, Sandmann, Mittelsten Scheid, Schmiemann \& Schoormans, 2007) used symbiotic strategies to implement context-related and in addition competence-based education [2].

In order to develop a research-based Leitbild together, in a first step we taught the educators about the educational framework, e.g. socio-scientific decision making, Sustainable Development etc. (see above). We offered workshops to the educators, which were guided by experts on the relevant field. For example, the workshop on socio-scientific decision making was guided by Prof. Susanne Bögeholz and Dr. Sabina Eggert, who established a competence model on decision making (Eggert \& Bögeholz, 2006). In addition, we provided the educators with relevant literature on latest research results. This one-year-long process was concluded with a focus group (figure 5; Bryman, 2004; Gayford, 2000; Bloor et al., 2001; Morgan, 1997), which served to discuss, argue and reflect upon educators' perceptions and beliefs regarding the 
scientific framework. The aims upon which the educators agreed were used to define goals and sub-goals as central parts of the new Leitbild. Focus groups have several advantages: Firstly, they provide educators with the opportunity to incorporate their own perceptions and beliefs, enabling a deeper level of meaning and important interlinking to be obtained. Furthermore, focus groups allow people to react to and build on the responses of other participants. Hence, they can contribute to including all aspects considered necessary for a biodiversity education (Stewart, Shamdasani \& Rook, 2007). With respect to the symbiotic strategy used, including educators' opinions in a focus group may increase their acceptance of the Leitbild for a new education programme (Parchmann et al., 2006). Since four educators and one coordinator work at the Heinz Sielmann Stiftung, only one focus group discussion (with all five referees) was conducted. The session was organised and steered by one of the scientific fellows (according to Morgan, 1997). To enable a purposeful discussion, we applied a semistructured interview guide (according to Krueger \& Casey, 2000; table 3). The guide focused on the innovative scientific and curricular concepts such as Sustainable Development, biodiversity, decision making and nature experience as potential goals, as well as on sub-goals and quality criteria. The entire discussion was videotaped and transcribed. Additionally, the moderator documented the Leitbild features for a first draft (Morgan, 1998). The draft was then sent to the educators in order to give them the opportunity to reflect on the discussion results. After two weeks, the group met again to talk about and improve the draft (according to Giesel, 2007).

Table 3. Excerpt from the interview guide - example of Sustainable Development

\begin{tabular}{||l||l||}
\hline \hline DISCUSSION AIM & POSSIBLE QUESTION \\
\hline \hline $\begin{array}{l}\text { Defining the goal with all its } \\
\text { related aspects }\end{array}$ & $\bullet \quad$ What are the central aspects of Sustainable Development? \\
\hline \hline $\begin{array}{l}\text { Defining sub-goals specifically } \\
\text { considered in Heinz Sielmann } \\
\text { Stiftung education }\end{array}$ & $\begin{array}{l}\text { - Which aspects of Sustainable Development do we want to } \\
\text { consider in the biodiversity education at Heinz Sielmann } \\
\text { Stiftung? }\end{array}$ \\
\hline \hline $\begin{array}{l}\text { Defining quality criteria for the } \\
\text { sub-goals }\end{array}$ & $\begin{array}{l}\text { Which quality criteria can we define to assess identified sub- } \\
\text { goals? }\end{array}$ \\
\hline \hline
\end{tabular}


According to the defined Leitbild, the working group developed four innovative educational courses: I Agriculture and Cultivated Landscape, II Settlement Area, III Landscape Conservation and IV Natural Succession (see results). In contrast to the ecology education programme that the educators had taught previously, the new courses focus on the conservation and a sustainable use of biodiversity, socio-scientific decision making and nature experiences related to biodiversity issues. Table 4 describes the educational shift.

Table 4. Focus Shift of Ecology Education to Leitbild-based biodiversity education

\begin{tabular}{|c|c|c|}
\hline & ECOLOGY EDUCATION & $\begin{array}{l}\text { LEITBILD-BASED BIODIVERSITY } \\
\text { EDUCATION }\end{array}$ \\
\hline 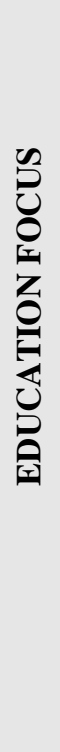 & $\begin{array}{l}\text { Students learn about... } \\
\text { - the anatomy and morphology } \\
\text { of animals and plants } \\
\text { - endangered species } \\
\text { - habitats of animals and plants } \\
\text { - the functioning of ecosystems } \\
\text { - projects to conserve } \\
\text { species and habitats }\end{array}$ & $\begin{array}{l}\text { Students learn about... } \\
\text { - the concept of Sustainable Development } \\
\text { - genetic diversity, diversity of species and } \\
\text { ecosystems (biodiversity) } \\
\text { - endangered biodiversity related to human impact } \\
\text { - opportunities to conserve biodiversity themselves } \\
\text { - ecological, economic and social interests } \\
\text { involved in decision-making processes for } \\
\text { Sustainable Development } \\
\text { - nature experience and scientific inquiry methods } \\
\text { and their role for socio-scientific decision making }\end{array}$ \\
\hline
\end{tabular}

We developed the courses for lower secondary school classes (student age 13-14) - one course for each season. The educators delivered each course twice (eight observations in all). On each occasion, approximately 30 secondary school students, who had never attended one of the new courses before, took part under the guidance of their class teachers. The educators took turns in carrying out the courses, meaning that each course was performed by a different educator. A scientific fellow who had already guided the focus group observed (according to Diekmann, 2007) the performances from a critical perspective. 
We used observations to assess the extent to which expected Leitbild quality criteria were fulfilled. An investigation by an external expert served to increase the validity and reliability of evaluation findings. We applied an observation guide (see appendix), which consisted of three parts: (a) formal aspects of course deliveries (e.g. date, number of students...), (b) the developed course-specific timetable, and (c) the Leitbild quality criteria that the focus group had defined (see results). To assess quality criteria, the observer used a scale from strongly fulfilled, to fulfilled, hardly fulfilled and not fulfilled. In addition, there was space for comments on achieved quality criteria. After every course delivery/ assessment, the educators and the observer met to reflect upon observation results and to use them to improve the courses systematically (Kuckartz et al., 2008). The whole process of developing, testing, assessing and improving new courses took the working group a further 12 months (figure 5). During this period, the educators had the opportunity to learn how to use the Leitbild to develop and deliver new courses. Furthermore, the process served to show them that reflecting upon and improving educational practice is crucial for developing educational quality (Wottawa $\&$ Thierau, 2003).

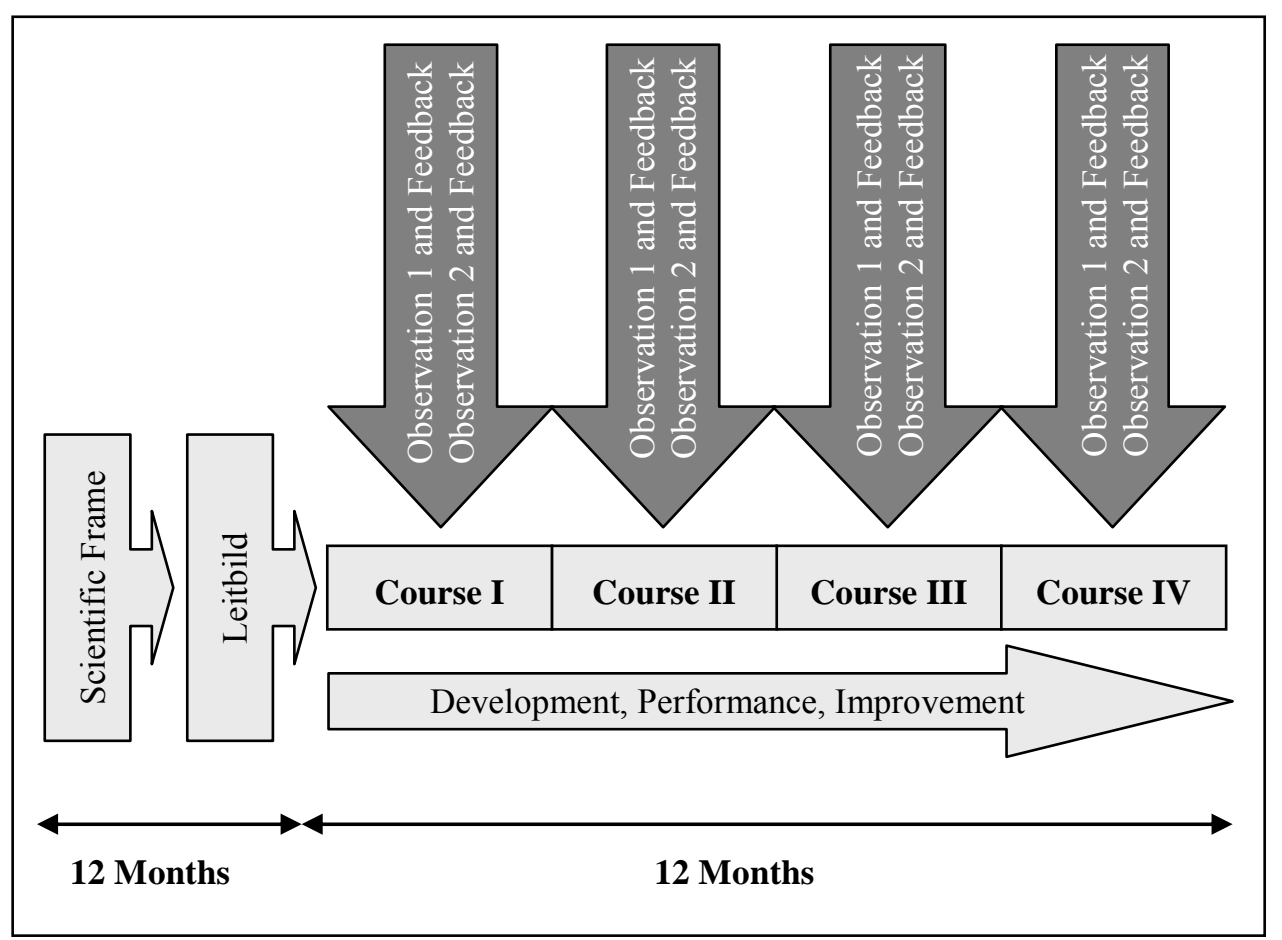

Figure 5. Study design 


\section{First results}

The working group identified a Leitbild for biodiversity education as having eight goals. Since the first four goals focus on the central concepts of Sustainable Development and biodiversity conservation itself (table 5), they form a significant part of the new Leitbild. With goal 1 Understanding Sustainable Development, we want students to understand the concept of Sustainable Development (according to WCED, 1987; de Haan et al., 2008). Students should become aware of conflicting interests and the role of interests for a Sustainable Development (Lundegard \& Wickman, 2007). Goal 2: Nature Conservation as a Positive Philosophy in Life reflects the motto of the Heinz Sielmann Stiftung. With this value-related goal, we focus on positive thinking towards nature conservation. Thirdly, with goal 3 Experience, Understanding, Appreciation and Conservation of Biodiversity, and goal 4 Understanding Succession, we address the concept of biodiversity in terms of its individual components, its endangerment as well as potential challenges for conserving programmes. Besides learning about the concept of biodiversity (following Mayer, 1996), we want students to learn about endangered biodiversity and the human impact thereupon (e.g. BMU, 2007; World Wide Fund for Nature (WWF), 2007). Furthermore, students should learn about opportunities to conserve biological diversity.

Additionally, the focus group identified a further three tool-like goals (table 6). With goal 5 Systematic Decision Making, we want students to connect factual knowledge with related values and norms in order to make systematic decisions in complex situations concerning the use of biodiversity. Factual knowledge can be gained by using Scientific Inquiry Methods (goal 6, Hammann, 2004; Bybee, 2004), whereas the values of nature can be pointed out by reflecting upon Nature Experiences (goal 7, Bögeholz, 2006b; Ballentyne, Conell \& Fien, 2007).

Since goals 1-7 are presented quite isolated from each other, we wished to show some important interlinking of the goals. Therefore, we defined goal 8 Cross-Linking Goals (table 7).

Each goal is divided into realisable sub-goals for new courses. Overall, there are 23 subgoals. According to the sub-goals, we established 57 quality criteria for quality assessment (see tables 5-7). 
Table 5. Core content Leitbild goals, sub-goals and quality criteria

\begin{tabular}{|c|c|c|}
\hline GOALS & $\begin{array}{l}\text { SUB-GOALS: STUDENTS } \\
\text { SHOULD... }\end{array}$ & QUALITY CRITERIA: EDUCATORS SHOULD.... \\
\hline \multirow{3}{*}{ 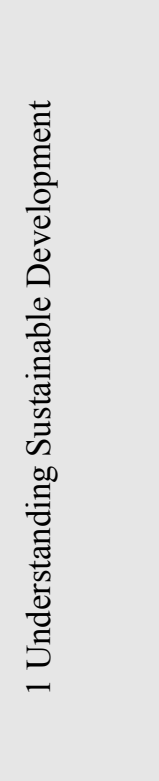 } & $\begin{array}{l}1.1 \text { learn about the concept of Sustainable } \\
\text { Development. }\end{array}$ & $\begin{array}{l}\text { 1.1.1 present the concept of Sustainable Development as a durable strategy for the whole world. } \\
\text { 1.1.2 focus on ecological, as well as on economic and social aspects. } \\
\text { 1.1.3 bring in opportunities to conserve biological diversity (and resources) for present and future } \\
\text { societies. } \\
\text { 1.1.4 show up examples of global effects by human impact. } \\
\text { 1.1.5 point out the right of every person to fulfil basic needs (enough food). }\end{array}$ \\
\hline & $\begin{array}{l}1.2 \text { get to know different interests and } \\
\text { goals, as well as conflicts of interests and } \\
\text { goals. }\end{array}$ & $\begin{array}{l}\text { 1.2.1 introduce different ecological and economic interests. } \\
\text { 1.2.2 work out variable legitimate options for development. } \\
\text { 1.2.3 demonstrate examples of resource dilemmas. }\end{array}$ \\
\hline & $\begin{array}{l}1.3 \text { learn about opportunities and ways to } \\
\text { conserve local and global resources. }\end{array}$ & $\begin{array}{l}\text { 1.3.1 point out variable strategies for resource conservation (e.g. biological diversity). } \\
\text { 1.3.2 introduce examples for sustainable production. }\end{array}$ \\
\hline \multirow{2}{*}{ 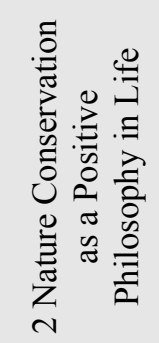 } & $\begin{array}{l}2.1 \text { adopt a positive attitude to nature } \\
\text { conservation as Heinz Sielmann did. }\end{array}$ & $\begin{array}{l}\text { 2.1.1 point out Sielmann's efforts on conservation of species and landscapes, as well as on his } \\
\text { success in nature conservation activities. }\end{array}$ \\
\hline & $\begin{array}{l}2.2 \text { learn about the motto of Heinz } \\
\text { Sielmann Stiftung. }\end{array}$ & $\begin{array}{l}\text { 2.2.1 provide positive experiences of nature and nature conservation. } \\
\text { 2.2.2 offer experiences which focus on the values of nature (e.g. by reflecting the role of nature in } \\
\text { students' lives). }\end{array}$ \\
\hline
\end{tabular}




\begin{tabular}{|c|c|c|}
\hline \multirow{4}{*}{ 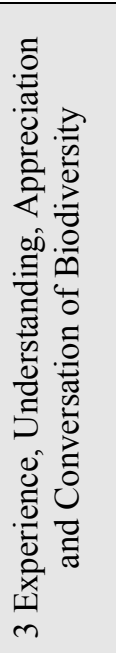 } & $\begin{array}{l}3.1 \text { understand the concept of biological } \\
\text { diversity. }\end{array}$ & $\begin{array}{l}\text { 3.1.1 point out genetic diversity. } \\
\text { 3.1.2 point out diversity of animals and plants. } \\
\text { 3.1.3 compare ecosystems of high biodiversity with ecosystems of low biodiversity. }\end{array}$ \\
\hline & $\begin{array}{l}3.2 \text { become aware of endangered } \\
\text { biodiversity. }\end{array}$ & $\begin{array}{l}\text { 3.2.1 introduce positive and negative results of people's use of genetic diversity. } \\
\text { 3.2.2 point out positive and negative consequences of people's use of species. } \\
\text { 3.2.3 work out positive and negative implications of human use of an ecosystem. }\end{array}$ \\
\hline & $\begin{array}{l}3.3 \text { learn about options to conserve } \\
\text { biodiversity. }\end{array}$ & $\begin{array}{l}\text { 3.3.1 point out opportunities and ways to conserve genetic diversity. } \\
\text { 3.3.2 introduce options to conserve habitats of plants and animals. } \\
\text { 3.3.3 introduce opportunities and ways to conserve ecosystems. }\end{array}$ \\
\hline & 3.4 recognise the role of neobiota. & 3.4.1 explain influences of neobiota on local biodiversity and give examples. \\
\hline \multirow{4}{*}{ 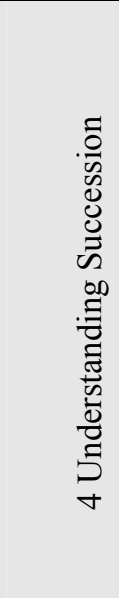 } & 4.1 become aware of natural landscape. & $\begin{array}{l}\text { 4.1.1 point out characteristic features of the wilderness. } \\
\text { 4.1.2 compare natural areas and cultivated landscape. }\end{array}$ \\
\hline & 4.2 identify natural succession processes. & 4.2.1 show students variable succession phases (e.g. after industrial use). \\
\hline & $\begin{array}{l}4.3 \text { learn about landscape changes by } \\
\text { succession and landscaping. }\end{array}$ & $\begin{array}{l}\text { 4.3.1 explain that landscape structures changes permanently. } \\
\text { 4.3.2 consider recultivated areas. }\end{array}$ \\
\hline & $\begin{array}{l}4.4 \text { get to know conservation projects and } \\
\text { protected areas of the Heinz Sielmann } \\
\text { Stiftung. }\end{array}$ & $\begin{array}{l}\text { 4.4.1 introduce endangered species, which } \mathrm{HSS}^{8}{ }^{8} \text { s conservation projects focus on. } \\
\text { 4.4.2 introduce endangered biotope types, which HSS's conservation projects focus on. } \\
\text { 4.4.3 focus on species indicating certain succession phases in HSS's nature protection areas. }\end{array}$ \\
\hline
\end{tabular}

${ }^{8}$ HSS $=$ Heinz Sielmann Stiftung

u 
Table 6. Tool-like Leitbild goals, sub-goals and quality criteria

\begin{tabular}{|c|c|c|}
\hline GOALS & SUB-GOALS: STUDENTS SHOULD... & QUALITY CRITERIA: EDUCATORS SHOULD.... \\
\hline \multirow{2}{*}{ 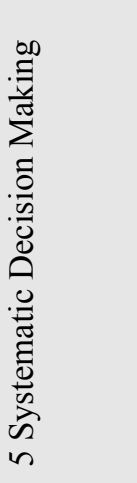 } & $\begin{array}{l}5.1 \text { acquire decision-making competencies by } \\
\text { application of the decision-making } \\
\text { competence model (after Eggert \& Bögeholz, } \\
\text { 2006). }\end{array}$ & $\begin{array}{l}\text { 5.1.1 offer learning activities, which reflect dimensions of the decision-making competence. } \\
\text { 5.1.2 help students to work out relevant information and to consequently reflect that information. } \\
\text { 5.1.3 assist students to connect factual information to relevant norms and value perspectives. } \\
\text { 5.1.4 help students to develop and reflect their conduction of decision-making processes. }\end{array}$ \\
\hline & $\begin{array}{l}5.2 \text { recognise their own values and the values } \\
\text { of other people, and relevant norms. }\end{array}$ & 5.2.1 provide decision-making processes, in which people's values and norms are pointed out. \\
\hline \multirow{3}{*}{ 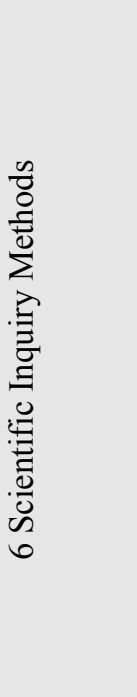 } & $\begin{array}{l}6.1 \text { acquire scientific competencies by } \\
\text { applying the competence model of } \\
\text { experimentation (after Tschirigi, 1980, } \\
\text { Hammann, 2004). }\end{array}$ & $\begin{array}{l}\text { 6.1.1 offer learning activities, which reflect the dimensions and the levels of the competence model } \\
\text { of experimentation. } \\
6.1 .2 \text { help students to develop hypotheses. } \\
6.1 .3 \text { help students to develop strategies to analyse these hypotheses. } \\
\text { 6.1.4 help students to analyse data. }\end{array}$ \\
\hline & $\begin{array}{l}6.2 \text { use scientific inquiry methods } \\
\text { appropriately to gain specific knowledge of } \\
\text { nature. }\end{array}$ & $\begin{array}{l}\text { 6.2.1 choose scientific inquiry methods adequately. } \\
6.2 .2 \text { apply chosen methods appropriately. }\end{array}$ \\
\hline & $\begin{array}{l}6.3 \text { learn to take ownership for their learning } \\
\text { as far as possible. }\end{array}$ & $\begin{array}{l}\text { 6.3.1 formulate tasks and learning targets according to age of students (age 13-14 and age 17-18). } \\
\text { 6.3.2 provide alternatives in reaching learning goals. }\end{array}$ \\
\hline
\end{tabular}




\begin{tabular}{|c|c|c|}
\hline & & $\begin{array}{l}\text { 6.3.3 appropriately help students to reach learning goals. } \\
6.3 .4 \text { provide students with enough time to reach learning goals by themselves. }{ }^{9}\end{array}$ \\
\hline 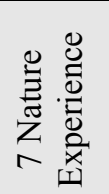 & $\begin{array}{l}7.1 \text { have positive nature experiences (after } \\
\text { Bögeholz, 2006b, Bögeholz, 1999). }\end{array}$ & $\begin{array}{l}\text { 7.1.1 motivate different types of nature experience. } \\
\text { 7.1.2 primarily provide aesthetic, scientific and ecological nature experiences. }\end{array}$ \\
\hline
\end{tabular}

${ }^{9}$ By now, quality criterion 6.3.4. is the only Leitbild criterion which reflects a didactical-methodical aspect for course development and delivery. 
Table 7. Cross-linking Leitbild goals, sub-goals and quality criteria

\begin{tabular}{|c|c|c|c|}
\hline GOAL & $\begin{array}{l}\text { LINKED } \\
\text { GOALS }\end{array}$ & SUB-GOALS: STUDENTS SHOULD... & QUALITY CRITERIA: EDUCATORS SHOULD.... \\
\hline \multirow{4}{*}{ 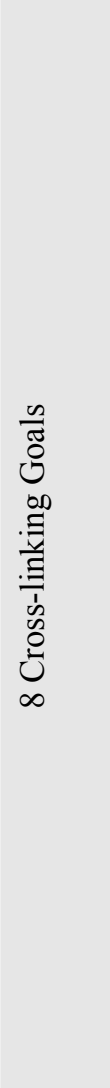 } & $\begin{array}{l}1 \\
2 \\
3 \\
5\end{array}$ & $\begin{array}{l}8.1 \text { make decisions aiming at Sustainable } \\
\text { Development (e.g. use of resources). }\end{array}$ & $\begin{array}{l}\text { 8.1.1 present understanding of Sustainable Development options (e.g. by decision } \\
\text { making regarding the use of biodiversity). } \\
8.1 .2 \text { offer tasks which can lead to variable answers to a Sustainable Development } \\
\text { problem. } \\
8.1 .3 \text { integrate ecological, economic and social-cultural aspects in decision-making } \\
\text { processes. }\end{array}$ \\
\hline & 1 & $\begin{array}{l}8.2 \text { be able to recognise sustainable and not } \\
\text { sustainable options for future developments. }\end{array}$ & $\begin{array}{l}\text { 8.2.1 consider variable options for action (sustainable, non sustainable) in decision- } \\
\text { making processes. }\end{array}$ \\
\hline & 6 & 8.3 use scientific methods in nature. & $\begin{array}{l}\text { 8.3.1 let students apply scientific methods in nature. } \\
\text { 8.3.2 combine scientific methods with dimensions of nature experience. } \\
\text { 8.3.3 let students reflect the role of scientific nature inquiry in their lives. }\end{array}$ \\
\hline & $\begin{array}{l}4 \\
5\end{array}$ & $\begin{array}{l}8.4 \text { recognize the values of nature (e.g. } \\
\text { Bögeholz, 2006b; Bögeholz, Bittner \& } \\
\text { Knolle, 2006; Ramsey, 1989). }\end{array}$ & $\begin{array}{l}\text { 8.4.1 offer discussions on the impact of positive and negative nature experiences on } \\
\text { students' attitude towards nature. } \\
\text { 8.4.2 help students reflecting values of nature. } \\
\text { 8.4.3 point out the ecological role of species and landscapes which can be negatively } \\
\text { experienced (e.g. spiders, bees, wilderness areas). }\end{array}$ \\
\hline
\end{tabular}


According to the new Leitbild, we developed four innovative courses: I Agriculture and Cultivated Landscape, II Settlement Area, III Landscape Conservation and IV Natural Succession (table 8). Each course aims to focus on a specific set of quality criteria with respect to all eight Leitbild goals. Thus, each course is said to have course-specific quality criteria [3]. Since they are specific for a course, their achievement is of central importance for course deliveries. Table 8 introduces the courses I-IV and their expected amount of course-specific quality criteria.

Table 8. Leitbild-based courses and course-specific quality criteria (c-s qc)

\begin{tabular}{|c|c|c|}
\hline COURSE & COURSE FOCUS & $\begin{array}{l}\text { TOTAL } \\
\text { OF C-S } \\
\text { QC }\end{array}$ \\
\hline $\begin{array}{l}\text { I Agriculture and } \\
\text { Cultivated } \\
\text { Landscape } \\
\text { (Autumn) }\end{array}$ & $\begin{array}{l}\text { Students learn about different types of cultivated ecosystems to } \\
\text { grow apples and their impact on biodiversity. Additionally, they } \\
\text { learn to decide systematically how to cultivate a landscape } \\
\text { considering ecological, economic and social parameters. }\end{array}$ & 31 \\
\hline $\begin{array}{l}\text { II Settlement } \\
\text { Areas } \\
\text { (Winter) }\end{array}$ & $\begin{array}{l}\text { Students learn about biodiversity in and outside their houses. The } \\
\text { human impact is pointed out. Furthermore, students plan to build } \\
\text { a settlement area considering habitats of plants and animals. }\end{array}$ & 35 \\
\hline $\begin{array}{l}\text { III Landscape } \\
\text { Conservation } \\
\text { (Spring) }\end{array}$ & $\begin{array}{l}\text { Students learn about the impact of conservation measures on } \\
\text { biodiversity in a park area. Considering all involved parameters, } \\
\text { they decide systematically how to develop the park. }\end{array}$ & 36 \\
\hline $\begin{array}{l}\text { IV Natural } \\
\text { Succession } \\
\text { (Summer) }\end{array}$ & $\begin{array}{l}\text { Students learn that landscape changes permanently. They learn } \\
\text { about different succession periods (e.g. meadow, forest) and their } \\
\text { impact on biodiversity in a conservation area, the previous border } \\
\text { between the two German states. Additionally, they have to } \\
\text { discuss and decide how to develop the border area. }\end{array}$ & 37 \\
\hline
\end{tabular}


Related to the determined course-specific quality criteria, each of the four courses addresses some of the Leitbild goals to a greater extent than others. Therefore, we defined course core profiles (CCP). To become a CCP goal, a course has to address:

a) Every criterion of a goal, $\underline{\text { or }}$

b) More quality criteria of a goal than the other three courses.

Whereas course I Agriculture and Cultivated Landscapes mostly refers to the goals 2, 5 and 7 [CCP $=$ goals 2, 5, 7], course II Settlement Areas mainly focuses on goals 1, 2 and 7. Course III Landscape Conservation mainly belongs to the goals 3 and 7, and course IV Natural Succession focuses on the goals 2, 4, 6 and 7. Figure 6 gives an overview.

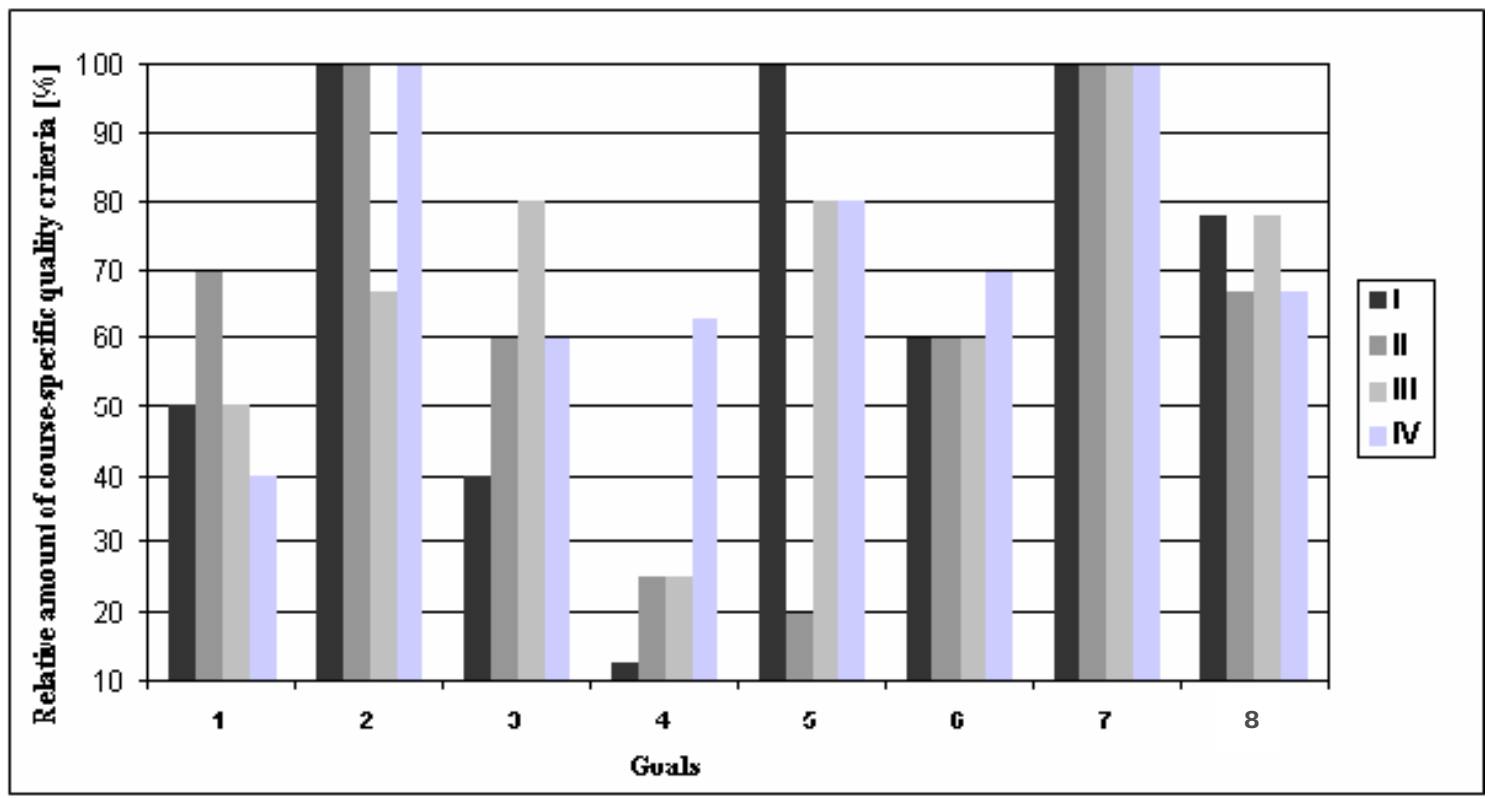

Figure 6. The goals addressed by the Leitbild-based courses - I Agriculture and Cultivated Landscapes, II Settlement Areas, III Landscape Conservation and IV Natural Succession

\section{Observation results}

In the delivery of the courses, we assessed the extent to which it was possible to achieve course-specific quality criteria. In all courses, educators most often fulfilled coursespecific quality criteria strongly or very strongly. Nevertheless, some deficits occurred as well. The following passages summarise findings of the eight observations. Due to 
concentrating on central information, we summarise very strongly and strongly fulfilled quality criteria as well fulfilled, whereas hardly and not fulfilled quality criteria are summed up as deficits. Table 9 provides an overview of the findings. Well-fulfilled criteria are presented as a “+”, whereas deficits are marked with a “-”. In the passages following table 9, deficits are pointed out detailed i) if they occur three times or more within the eight course deliveries, ii) if they occur in both performances of a course and/or iii) if they belong to a course's CCP.

Table 9. Achievement of course-specific quality criteria in course performances

\begin{tabular}{|c|c|c|c|c|c|c|c|c|c|}
\hline \multirow[t]{2}{*}{ Goals } & \multirow{2}{*}{$\begin{array}{l}\text { Quality } \\
\text { Criteria }\end{array}$} & \multicolumn{2}{|c|}{ Course I } & \multicolumn{2}{|c|}{ Course II } & \multicolumn{2}{|c|}{ Course III } & \multicolumn{2}{|c|}{ Course IV } \\
\hline & & 1 & 2 & 1 & 2 & 1 & 2 & 1 & 2 \\
\hline \multirow{3}{*}{ 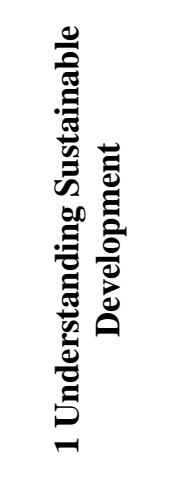 } & $\begin{array}{l}1.1 .1 \\
1.1 .2 \\
1.1 .3 \\
1.1 .4 \\
1.1 .5\end{array}$ & $\begin{array}{l}+ \\
+ \\
+\end{array}$ & $\begin{array}{l}+ \\
+ \\
+\end{array}$ & $\begin{array}{l}+ \\
+ \\
+\end{array}$ & $\begin{array}{l}+ \\
+ \\
+\end{array}$ & + & + & + & + \\
\hline & $\begin{array}{l}1.2 .1 \\
1.2 .2 \\
1.2 .3 \\
\end{array}$ & $\begin{array}{l}+ \\
+\end{array}$ & $\begin{array}{l}+ \\
+\end{array}$ & + & + & $\begin{array}{l}+ \\
+\end{array}$ & $\begin{array}{l}+ \\
+\end{array}$ & $\begin{array}{l}+ \\
+ \\
-\end{array}$ & $\begin{array}{l}+ \\
- \\
-\end{array}$ \\
\hline & $\begin{array}{l}1.3 .1 \\
1.3 .2\end{array}$ & $\begin{array}{l}+ \\
+\end{array}$ & $\begin{array}{l}+ \\
+\end{array}$ & + & + & $\begin{array}{l}- \\
+\end{array}$ & $\begin{array}{l}- \\
+\end{array}$ & & \\
\hline \multirow{2}{*}{ 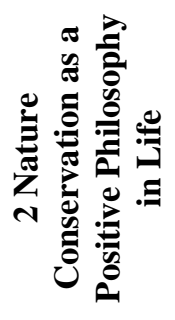 } & 2.1.1 & - & + & + & + & & & - & - \\
\hline & $\begin{array}{l}2.2 .1 \\
2.2 .2\end{array}$ & $\begin{array}{l}+ \\
+\end{array}$ & $\begin{array}{l}+ \\
+\end{array}$ & $\begin{array}{l}+ \\
+\end{array}$ & $\begin{array}{l}+ \\
+\end{array}$ & $\begin{array}{l}+ \\
-\end{array}$ & $\begin{array}{l}+ \\
+\end{array}$ & $\begin{array}{l}+ \\
+\end{array}$ & $\begin{array}{l}+ \\
+\end{array}$ \\
\hline \multirow{4}{*}{ 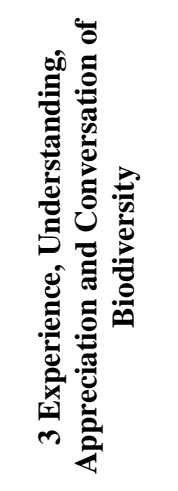 } & $\begin{array}{l}3.1 .1 \\
3.1 .2 \\
3.1 .3\end{array}$ & + & + & $\begin{array}{l}+ \\
+\end{array}$ & $\begin{array}{l}+ \\
+\end{array}$ & $\begin{array}{l}+ \\
+\end{array}$ & $\begin{array}{l}- \\
+\end{array}$ & + & $\begin{array}{l}+ \\
-\end{array}$ \\
\hline & $\begin{array}{l}3.2 .1 \\
3.2 .2 \\
3.2 .3\end{array}$ & + & + & $\begin{array}{l}+ \\
+\end{array}$ & $\begin{array}{l}+ \\
+\end{array}$ & $\begin{array}{l}+ \\
+ \\
+\end{array}$ & $\begin{array}{l}- \\
+ \\
+\end{array}$ & + & $\begin{array}{l}+ \\
+\end{array}$ \\
\hline & $\begin{array}{l}3.3 .1 \\
3.3 .2 \\
3.3 .3\end{array}$ & + & + & $\begin{array}{l}+ \\
+\end{array}$ & $\begin{array}{l}+ \\
+\end{array}$ & $\begin{array}{l}+ \\
+ \\
+\end{array}$ & $\begin{array}{l}- \\
+ \\
+\end{array}$ & - & $\begin{array}{l}+ \\
+\end{array}$ \\
\hline & 3.4.1 & & & & & & & & \\
\hline
\end{tabular}


As can be seen in table 9, educators succeeded in fulfilling quality criteria of goal 1 Understanding Sustainable Development in performances of the courses I and II. Some difficulties occurred in the courses III and IV. For example, 1.2.3 to demonstrate examples of resource dilemmas was inadequately reached in the two deliveries of course IV. The criterion 1.3.1 to point out variable strategies for resource conservation (e.g. biological diversity) could not be met in both performances of course III. The deficits found do not belong to any CCP.

Regarding goal 2 Nature Conservation as a Positive Philosophy in Life, course-specific quality criteria were well met in both deliveries of course II. Some deficits were measured within the performance of courses I, III and IV. Whereas deficits in courses I and III only occurred in the first performance, deficits in course IV were measured in both deliveries. Especially the criterion, 2.1.1 to point out Sielmann's efforts on conservation of species and landscapes, as well as on his success in nature conservation activities, was not reached frequently. With respect to goal 2, deficits found in courses I and IV belong to their CCPs.

Regarding goal 3 Experience, Understanding, Appreciation and Conversation of Biodiversity, educators fulfilled course-specific quality criteria well in courses I and II. Difficulties occurred in courses III and IV. Goal 3 is a core profile goal for course III. Here, educators had difficulty in teaching about genetic biodiversity in performance 2 . Besides 3.1.1 and 3.2.1, 3.3.1 to point out opportunities and ways to conserve genetic diversity was not met. Deficits in course IV occurred in both deliveries. For instance, 3.1.3 to compare ecosystems of high biodiversity with ecosystems of low biodiversity could not be reached.

With respect to goal 4 Understanding Succession, course-specific quality criteria were fulfilled in courses I, III and IV. Deficits were measured only in course II. Here, criterion, 4.4.2 to introduce endangered biotope types, upon which the conservation projects of the Heinz Sielmann Stiftung focus, was not reached in both performances. The deficits found do not belong to the CCP of course II.

Goal 5 Systematic Decision Making could not be adequately fulfilled in any new course. Practitioners almost always had difficulty in teaching decision-making processes. Most often, deficits were related to realising the competence model for decision making (following Eggert \& Bögeholz, 2006). For example, the criterion 5.1.2 to help students 
to work out relevant information and to consequently reflect upon that information could not adequately be met in deliveries of course I. Deficits found in course I belong to the course's CCP.

Course-specific quality criteria according to goal 6 Scientific Inquiry Methods were most often well fulfilled. Slight deficits occurred, for instance, in course IV: 6.3.4 to provide students with enough time to reach learning goals by themselves. The deficit found in course IV refers to the course's CCP.

Goal 7 Nature Experience was achieved well in all deliveries. Here, difficulties did not occur at all. Goal 7 belongs to the CCPs of all four courses.

Regarding goal 8, Cross-linking goals, educators fulfilled course-specific quality criteria in performances of courses I and III. Some difficulties occurred in courses II and IV. For course II, 8.4.2 to help students to reflect upon values of nature could not be reached in both performances. The deficits found do not refer to the courses' CCPs.

\section{Discussion}

The new Leitbild goals and sub-goals focus on competences that are crucial for an extra-curricular biodiversity education at the Heinz Sielmann Stiftung. Since the Leitbild goals are the results of the focus group, they represent our specific approach to contribute to

(a) ESD (Bormann \& de Haan, 2008; BMZ/KMK, 2007), especially biodiversity education (CBD, 1992; BMU, 2007; Lindemann-Matthies et al., 2009),

(b) Curricular requirements (KMK, 2005; Niedersächsisches Kultusministerium, 2007, 2008), and

(c) The Heinz Sielmann Stiftung guidelines for their educational practice (figure 4, Bögeholz, Stelte \& Säger, 2005).

Since biodiversity is an interdisciplinary and highly complex issue (Gayford, 2000; Grace, 2008), students do not solely learn about the biological concept of biodiversity and its three components in Heinz Sielmann Stiftung Leitbild courses (e.g. CBD, 1992, Mayer, 1996); they also learn about endangered biodiversity, human impact on biodiversity and about opportunities to contribute to biodiversity conservation in a 
sustainable manner (see goals 1, 2, 3, 8, according to de Haan, 2006; BMU, 2007). Students can learn about succession in particular (goal 4, e.g. Scherzinger, 1997). Hence, they can learn about the changing landscape and its impact on biodiversity. Furthermore, decision making on how to use a specific landscape - reflecting upon economic, ecological and social parameters - serve students in gaining competences necessary to develop their environment in a sustainable way. The corresponding parameters involve factual as well as ethical information (Bögeholz \& Barkmann, 2003). They are fundamental for decision making regarding socio-scientific issues (goals 5 and 8, Eggert \& Bögeholz, 2006). Accordingly, nature experiences play an important role (goal 7, Bögeholz, 2006b; Ballentyne, Conell \& Fien, 2007). By reflecting on their experiences of nature (goals 7 and 8, Bögeholz, 2006b), students acquire facts on biodiversity (factual information). In addition, they can realise the values of biodiversity (ethical information). At the Heinz Sielmann Stiftung, students get the opportunity to experience nature by applying scientific inquiry methods (goal 6, e.g. Hammann, 2004; Bybee, 2004). Investigating ecosystem-specific ecological parameters can serve students in understanding relationships between living and nonliving components of an ecosystem.

Besides goals and sub-goals, the Leitbild also consists of quality criteria. Practitioners can use these as a guideline for new courses, or as evaluation tools to measure, monitor and improve course quality. We transferred the Leitbild into four new prototype courses, one course for each season. Every course has a core profile (CCPs, figure 6), related to course-specific goals and quality criteria. Since educators often succeeded in fulfilling course-specific Leitbild quality criteria and achieved goals according to the CCPs (table 9), a high quality of courses in terms of an achievement of the new Leitbild can be claimed. It can be highlighted that educators always succeeded in fulfilling course-specific quality criteria linked with goal 7, Nature Experience (table 9). An explanation for this finding is that the educators already offered nature experiences before the Leitbild was defined. Similar to goal 7, educators showed only slight difficulties with respect to goal 4, Understanding Succession and goal 6 Scientific Inquiry Methods (table 9). This finding can be linked with the educators' "original" professions. Since most educators studied biology, forestry or agriculture, they have specific competence in this area, e.g. competence linked with investigating succession areas and using scientific inquiry methods. 
Nevertheless, some goals could not be reached adequately. Regarding all delivered courses, educators often showed slight difficulty in fulfilling quality criteria according to goal 2, Nature Conservation as a Positive Philosophy in Life - even though the goal belonged to the courses' core profiles (table 9). In feedback discussions, educators often argued that they experienced quality criteria according to goal 2 as artificial and unsuitable. For example, when teaching decision making to students, there seemed to be little opportunity to link it with the efforts of Heinz Sielmann (2.1.1). Thus, a future task for the Leitbild work at the Heinz Sielmann Stiftung will be to reconsider this goal and its components.

Besides goal 2, educators had further difficulties in fulfilling quality criteria belonging to goal 5, Systematic Decision Making (table 9), in almost every course delivery. More precisely, they showed difficulties in working with the competence model for decision making (by Eggert \& Bögeholz, 2006). A possible reason for the deficits found is that systematic decision making is a very new competence area in education offered by the Heinz Sielmann Stiftung (and for German school education in general; KMK, 2005). Research on the competence model by Eggert \& Bögeholz (2006) is still in progress, since a validation of all competence dimensions has not yet been completed. Practitioners were teaching the innovative decision-making methods for their first time. Therefore, it seems likely that performances can be improved firstly through more practice, and secondly through more research-based insights into applying the competence model (ibid.).

Whereas goals 2 and 5 were inadequately fulfilled in all four courses, difficulties in achieving other goals only occurred with respect to particular courses: Regarding goal 1, Understanding Sustainable Development and goal 3 Experience, Understanding, Appreciation and Conversation of Biodiversity, deficits occurred only in performances of courses III and IV. Three reasons can be cited to explain this finding. Firstly, since every course was delivered to different students, educators had to cope with differing prior knowledge between learning groups. Students who attended course III in particular had difficulties in learning, since their prior knowledge was lower than expected. Accordingly, educators left out information that they believed to be too difficult for these learning groups (e.g. on genetic biodiversity; 3.1.1, 3.2.1, 3.3.1). In order to improve future course deliveries, educators should interview class teachers on students' prior knowledge before the beginning of a course. In this way, they can identify already 
existing competences of students and use such information to adapt courses to the specific learning groups in a better manner. A second explanation might lie in the unexpected weather conditions. Since courses mostly take place outside, moderate weather is important for a course delivery. Unfortunately, both of the performances of course III took place in the rain, whereas both of the deliveries of course IV took place in the heat. In order to manage these situations, educators had to change their course plans slightly. For example, students' classifications of plants specific for a biotope were cancelled and replaced by the educators' descriptions and explanations. As a consequence, they failed to fulfil certain quality criteria - even if they were linked with a course profile (table 9). For future deliveries, it will be important to be prepared for different weather conditions. Finally, a reason for the assessed deficits can be seen in the lack of educational profession of educators. Since most of them are natural scientists, they have not learned about general criteria for good learning and instruction (e.g. Götz \& Häfner, 2004). Accordingly, they often have difficulties in achieving didactical-methodical requirements in general. For instance, educators have difficulties in using available course time efficiently. As can be seen in the second carrying out of course IV, educators failed to achieve the quality criterion 6.3.4, in providing students with enough time to reach their learning goals by themselves. Far too much time was used for discussing ecological, economic and social parameters involved in a biodiversity problem. At the end of the course, there was not sufficient time to reach further course goals and thus any more course-specific quality criteria. To improve their performances, educators need to pay more attention to general methodological und didactical criteria for learning and instruction (e.g. Götz \& Häfner, 2004). In this respect, training courses on teaching skills could be helpful.

With regard to goal, 8 Cross-Linked Goals, educators often failed to achieve coursespecific quality criteria on offering value reflections of nature (8.4.2) in deliveries of course II and IV. Value reflection is a fundamental part of decision-making processes (Eggert \& Bögeholz, 2006). We therefore assume that already mentioned difficulties with goal 5 can have an impact on difficulties detected for goal 8, which interlinks goal 5 with other goals. In order to improve deliveries of goal 8, educators probably need training support in teaching decision-making processes. 


\section{Critical remarks on the scientific approach}

This study is a first part of a formative evaluation of a biodiversity education programme for extra-curricular learning at Heinz Sielmann Stiftung. Using a focus group to develop a new Leitbild on education has positive as well as negative impacts. Fostering educators' motivation, identification and orientation are potentially positive effects linked with a Leitbild (see above; Giesel, 2007). However, whereas the groups themselves decide on group goals and group sub-goals, individual beliefs, which can differ from group decisions, cannot always be met. Thus, individual thinking about teaching and learning still exists parallel to the new Leitbild (Giesel, 2007). Knowing about educators' beliefs is important for teaching (Cotton, 2006) since, for example, negative attitudes towards the new Leitbild can be a barrier to course delivery (according to the Theory of Planned Behavior by Ajzen, 2005). As yet, we do not know to what extent parallel beliefs of the assessed educators exist, since neither a focus group nor an observation are useful instruments for this purpose. For further investigations, interviews with educators will be helpful in order to learn more about educators' beliefs (Bortz \& Döring, 2006). Within the project, an interview study is being used to this aim. First results show that i) the educators' attitudes towards the Leitbild, ii) the expectations of other persons who are important to the educators, and iii) beliefs on conditions that influence the application of the Leitbild (following Ajzen, 2005) play an important role.

With respect to observations, we tried to assess the quality of courses according to the new Leitbild, taking course-specific quality criteria fairly strongly into consideration (approx. 35 criteria per course, see table 8) in every delivery. It should be conceded that assessing so many quality criteria is only practicable for an evaluator who is familiar with them - as was indeed the case here. New evaluators would need intensive training. Furthermore, it is simply not possible for educators to consider approximately 35 different quality criteria in one single performance, even if they are familiar with the quality criteria and have planned courses precisely according to them. Furthermore, we applied the quality criteria as they are presented in the tables 5-7. Although it was possible to measure most quality criteria well, some criteria were nevertheless hard to assess. For example, 6.1.1, to offer learning activities, which reflect the dimensions and the levels of the competence model of experimentation cannot be measured well since the criterion is not formulated with sufficient precision. Rather, it is an all- 
encompassing criterion, which focuses on all dimensions and levels of the competence model at the same time, without differentiating between them. Planning future deliveries and observations, it is surely better to reduce (course-specific) quality criteria ant to concentrate on a more practicable limit. Furthermore, we need to rework "problematic" quality criteria in order to improve the measurability of courses.

After each observation, the educators and the researchers discussed difficulties and tried to optimise teaching. Here, educators had the opportunity to learn to reflect upon their teaching precisely (as called for, for instance by Papoulia-Tzelepi, 1996). Subsequently, some improvements from delivery 1 to delivery 2 were detected (table 9). Since we assessed only two performances per course, we do not know whether further improvements would occur in a third or fourth performance. Further observations of each course would have been helpful in order to discern this.

Since the working group developed and tested a Leitbild that reflects new educational challenges in a first step, a second step will be to review the Leitbild critically in order to improve its practicability (Giesel, 2007). Besides reflecting upon goals, sub-goals and quality criteria, it should be considered how to develop the educators' competences in terms of didactical-methodical aspects (e.g. Götz \& Häfner, 2004). A second focus group will serve for this investigation.

Nevertheless, the study has shown that developing a Leitbild is crucial for assessing and improving educational practices. Concrete goals and sub-goals serve to guide educational practice in an education centre like the Heinz Sielmann Stiftung. They are helpful in guiding the development and performance of courses, which can contribute to (competence-oriented) school education. Derived quality criteria are useful tools to assess the quality of courses. Researchers' mentoring serves to scientifically guide educators' Leitbild work, whereas educators' practical experiences complement the scientific framework. Therefore, we assume that the methodological approach used here can be an appropriate model for developing (extra-curricular) educational quality in general. 


\section{Notes}

[1] Heinz Sielmann (1917-2006) was a famous nature photographer. With his photographs and films, he explored the lives of animals, e.g. on Galapagos. He and his wife founded the Heinz Sielmann Stiftung in 1994. The foundation aims at contributing to nature conservation and enhancing biodiversity education.

[2] For example, Chemie im Kontext (chik) and Biologie im Kontext (bik) involves a cooperative work of scientists and teachers. The working group of scientists provides teachers of chemistry and teachers of biology with guidelines, examples, suggestions and material, whereas the teachers designed their own lessons based on the given framework.

[3] Besides course-specific quality criteria, we identified optional and complementary quality criteria for the courses. They are of less importance for particular course deliveries. For more detailed information on the achievement of course-specific, optional and complementary quality criteria, please contact the authors. 


\subsection{Teilstudie 2: Subjektive Einschätzungen von Umweltbildner(inne)n in Bezug} auf ein neues Leitbild zur Biodiversitätsbildung - Ein Beitrag zur formativen Evaluation $^{10}$

Dargestellt wird eine Studie zur formativen Evaluation außerschulischer Maßnahmen zur Biodiversitätsbildung nach einem Leitbild. Das Leitbild dient als Orientierungsrahmen für die Gestaltung kompetenzorientierter Bildungsmaßnahmen zum Schutz und zur Nachhaltigen Nutzung von Biodiversität. Um einschätzen zu können, inwieweit die bisherigen Erfahrungen im Umgang mit dem neuen Leitbild die Absicht der Umweltbildner(innen) beeinflussen, Veranstaltungen nach dem Leitbild zu gestalten, wurde eine Interviewstudie unter Verwendung der Theory of Planned Behavior (Ajzen, 2008, 2005) durchgeführt. Die Untersuchung zeigt, dass die Umweltbildner(innen) überwiegend beabsichtigen, Veranstaltungen nach dem Leitbild zu gestalten. Dennoch werden auch Barrieren, wie z.B. Rahmenbedingungen für Veranstaltungen, identifiziert, die eine Leitbildarbeit gefährden können. Der Beitrag betont die Relevanz subjektiver Einschätzungen von Lehrenden für eine innovative, leitbildbasierte Bildungsarbeit. Um wahrgenommenen Schwierigkeiten begegnen zu können, werden Handlungsempfehlungen aufgezeigt.

The investigation formatively assesses the new biodiversity education courses offered by an environmental education centre. For this, educators and researchers developed a Leitbild for educational investigations (Giesel, 2007). Furthermore, they developed, tested and optimised new courses according to the new Leitbild. The experiences educators had can influence their intention to develop and deliver Leitbild courses. To find out educators' intentions we applied the Theory of Planned Behavior (Ajzen, 2008, 2005) in an interview study. The results showed that educators most often intend to use the new Leitbild in their educational practice. Nevertheless, we identified some barriers as well. For example, educators criticised the setting of new courses. The study emphasises the relevance of educators' intentions for educational innovations. It further points out possible solutions to optimise the educational process.

${ }^{10}$ Manuskript in Vorbereitung zur Publikation in einer wissenschaftlichen Zeitschrift. 


\section{Einleitung}

Um kompetenzbasierten Biologieunterricht $\mathrm{zu}$ Biodiversität möglichst optimal unterstützen zu können, hat eine Arbeitsgruppe aus Umweltbildner(inne)n der Heinz Sielmann Stiftung und Biologiedidaktiker(inne)n im Rahmen einer formativen Evaluation ein Leitbild zum Schutz und zur Nachhaltigen Nutzung von Biodiversität entwickelt, erprobt und systematisch optimiert. Das neue Leitbild orientiert sich zum einen am Stand der Forschung zu Bildung für Nachhaltige Entwicklung, insbesondere zu Bildung für Biodiversität (CBD, 1992; BMU, 2007; BMBF, 2006), zum anderen an curricularen Vorgaben (KMK, 2005; Niedersächsisches Kultusministerium, 2007, 2008) sowie an den umweltpädagogischen Leitlinien der Heinz Sielmann Stiftung (Bögeholz, Stelte \& Säger, 2005). Nach Ajzen (2005, 2008) können die Erfahrungen bei der Entwicklung, Erprobung und Optimierung eines neuen Leitbildes dazu beitragen, die Absicht von Umweltbildner(inne)n zu beeinflussen, Veranstaltungen nach dem Leitbild $\mathrm{zu}$ gestalten. Um eine leitbildbasierte Biodiversitätsbildung optimierend steuern zu können, ist eine Untersuchung der subjektiven Einschätzungen der Umweltbildner(innen) damit zentral (vgl. auch Graf, 2007; Gräsel \& Parchmann, 2004; Blömeke, Eichler \& Müller, 2003; Helmke, 2009).

\section{Theoretischer Hintergrund}

Die vorliegende Untersuchung dient der formativen Evaluation einer leitbildbasierten Biodiversitätsbildung an einem außerschulischen Lernort, der Heinz Sielmann Stiftung. Ziel des Evaluationsvorhabens ist es, die Qualität neuer Bildungsprogramme zu überprüfen und zu optimieren (Wottawa \& Thierau, 2003; Bortz \& Döring, 2006). Hierfür wurde zunächst ein Leitbild (Giesel, 2007) entwickelt und erprobt. Leitbilder sind Zielsetzungen. Sie stellen ein Orientierungsmuster dar, das ein zielgerichtetes Denken und Handeln fördern soll (Giesel, 2007). Das Leitbild für die Biodiversitätsbildung der Heinz Sielmann Stiftung dient dazu, innovative Bildungsveranstaltungen zum Schutz und zur Nachhaltigen Nutzung von Biodiversität systematisch zu entwickeln, umzusetzen und zu optimieren. Es orientiert sich an den folgenden Bildungszielen. 
- Zum einen fokussiert das neue Leitbild auf Bildung für Nachhaltige Entwicklung, insbesondere einer Bildung zu Biodiversität (CBD, 1992; BMU, 2007; BMBF, 2006). Ziel ist es, die Gefährdung von Biodiversität in Bildungsveranstaltungen aufzuzeigen sowie Schüler(innen) zu befähigen, sich aktiv am Schutz und einer Nachhaltigen Nutzung von Biodiversität zu beteiligen.

- Des Weiteren orientiert sich das neue Leitbild an kompetenzorientierten curricularen Vorgaben, insbesondere den Kompetenzbereichen Erkenntnisgewinnung und Bewertung des Faches Biologie (KMK, 2005; Niedersächsisches Kultusministerium, 2007, 2008). Schüler(innen) sollen lernen, naturwissenschaftliche Arbeitsweisen (z.B. Hammann, 2004) zielgerichtet anzuwenden, um Informationen über Biodiversität zu generieren. Zudem sollen sie lernen, (mitunter gleichwertige) Handlungsoptionen zum Umgang mit Biodiversität systematisch miteinander zu vergleichen, um zu tragfähigen Entscheidungen zu gelangen (Eggert \& Bögeholz, 2006; Bögeholz, 2007).

- Drittens berücksichtigt das neue Leitbild die umweltpädagogischen Leitlinien der Heinz Sielmann Stiftung (Bögeholz, Stelte \& Säger, 2005). Die Leitlinien stellen einen übergeordneten Orientierungsrahmen für alle Bildungsmaßnahmen der Stiftung dar. Eine zentrale Leitlinie ist das Erleben, Erkennen, Verstehen, Wertschätzen und Erhalten biologischer Vielfalt (Biodiversität).

Für das neue Leitbild hat die Arbeitsgruppe aus Praxis und Wissenschaft acht zentrale Ziele erarbeitet. Diese wurden in 23 Teilziele ausdifferenziert. Für jedes Teilziel wurden zudem Qualitätsmerkmale (insgesamt 57) entwickelt, um eine Zielerfüllung in Veranstaltungen überprüfen zu können (nach Schratz, 2003; Wottawa \& Thierau, 2003). Tabelle 10 zeigt einen Ausschnitt aus dem festgelegten Leitbild zum Zielbereich Nachhaltige Entwicklung. 
Tabelle 10. Auszug aus dem Leitbild der Biodiversitätsbildung der Heinz Sielmann Stiftung - Beispiel Nachhaltige Entwicklung

\begin{tabular}{|c|c|c|}
\hline ZIEL & $\begin{array}{l}\text { TEILZIELE - DIE } \\
\text { VERANSTALTUNG } \\
\text { ZIELT AUF: }\end{array}$ & $\begin{array}{l}\text { UMWELTBILDNER(INNEN) ERFÜLLEN FOLGENDE } \\
\text { QUALITÄTSMERKMALE: }\end{array}$ \\
\hline \multirow[t]{3}{*}{ 告 } & $\begin{array}{l}\text { - Ein Kennenlernen } \\
\text { des Leitbildes der } \\
\text { Nachhaltigen } \\
\text { Entwicklung }\end{array}$ & $\begin{array}{l}\text { - Als zukunftsfähiges Leitbild der Welt-Gesellschaft wird } \\
\text { das Konzept der Nachhaltigen Entwicklung aufgezeigt. } \\
\text { Die Mitarbeiter(innen) Umweltbildung sprechen neben } \\
\text { ökologischen auch ökonomische und soziale Aspekte an. } \\
\text { - Die Mitarbeiter(innen) Umweltbildung zeigen an } \\
\text { Beispielen auf, wie wir biologische Vielfalt (und } \\
\text { Ressourcen) erhalten können, damit sie auch noch } \\
\text { unseren Kindern zur Verfügung stehen. } \\
\text { Die Mitarbeiter(innen) Umweltbildung zeigen an } \\
\text { Beispielen auf, wie unser Handeln global Auswirkungen } \\
\text { haben kann. } \\
\text { Die Mitarbeiter(innen) Umweltbildung zeigen an } \\
\text { Beispielen auf, dass alle Menschen ein Recht haben, ihre } \\
\text { Grundbedürfnisse zu befriedigen (ausreichend Nahrung). }\end{array}$ \\
\hline & $\begin{array}{l}\text { Ein Erkennen von } \\
\text { Interessen und } \\
\text { Zielen sowie } \\
\text { Interessens- und } \\
\text { Zielkonflikten }\end{array}$ & $\begin{array}{l}\text { - Unterschiedliche Interessen im Spannungsfeld z.B. von } \\
\text { Ökologie und Ökonomie werden aufgezeigt. } \\
\text { - Unterschiedliche mögliche legitime Ziele für } \\
\text { Gestaltungsfragen werden erarbeitet. } \\
\text { - Ressourcen-Nutzungs-Dilemmata werden verdeutlicht. }\end{array}$ \\
\hline & $(\ldots)$ & $(\ldots)$ \\
\hline
\end{tabular}

Im Rahmen des Evaluationsvorhabens wurde das Leitbild in vier innovativen Veranstaltungen für die Sekundarstufen I erprobt. Die gewonnenen Erfahrungen der Umweltbildner(innen) bei der gemeinsam begonnenen Entwicklung und Umsetzung des neuen Leitbildes können ihre Entscheidung beeinflussen, weiterhin Veranstaltungen nach dem Leitbild zu gestalten (Ajzen, 2005; Reinmann-Rothmeier \& Mandl, 1999). Um in einem weiteren Arbeitsschritt der Evaluationsstudie untersuchen zu können, inwieweit die Umweltbildner(innen) sich am Leitbild orientieren wollen, wurde die Theory of Planned Behavior [TOPB] (Ajzen, 2008, 2005; siehe Abbildung 7) eingesetzt. Die Theorie erhebt den Anspruch, Handlungen vorherzusagen und zu erklären, denen bewusste Planungsüberlegungen vorausgehen. Dabei wird ein geplantes Verhalten als „Konsequenz einer systematischen Analyse aller zur Verfügung stehenden relevanten Informationen angesehen "(Graf, 2007, S. 35 nach Ajzen, 2005). In Anlehnung an die TOPB (Ajzen, 2008, 2005) wird in dieser Studie angenommen, dass 
eine Orientierung am Leitbild durch die Absicht der Umweltbildner(innen), sich am Leitbild zu orientieren, vorhergesagt werden kann. Die Absicht stellt eine bewusste Entscheidung der Umweltbildner(innen) dar. Sie kann als Maß dafür aufgefasst werden, wie viele Anstrengungen ein(e) Umweltbildner(in) unternehmen möchte, sich am Leitbild zu orientieren (Ajzen, 2005, 2008; vgl. Erten, 2000). Die Absicht wird im Kernmodell der Theorie (1. Theorieebene, Abbildung 7) von der persönlichen Einstellung gegenüber der Leitbildarbeit, der sozialen subjektiven Norm und der kontrollierenden wahrgenommenen Verhaltenskontrolle bestimmt (Ajzen, 1985). Auf einer zweiten Theorieebene werden die Konstrukte durch u. a. erfahrungsbasierte subjektive Überzeugungen der Umweltbildner(innen) bestimmt und erklärt (Ajzen, 2008, 2005; Abbildung 7).

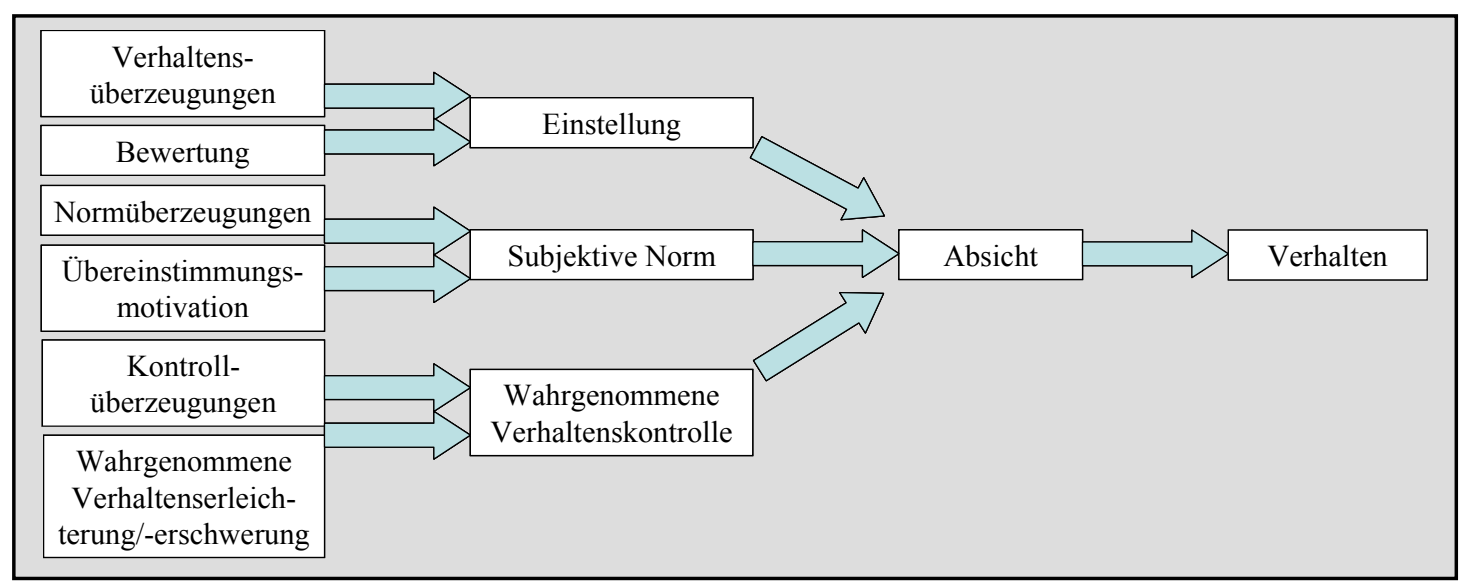

Abbildung 7. Theory of Planned Behavior (verändert nach Ajzen, 2005)

Die Einstellung gegenüber der Leitbildarbeit ist konzipiert als allgemeine Bewertung einer Orientierung am Leitbild. Sie beschreibt, wie positiv oder negativ die Umweltbildner(innen) einer Orientierung am Leitbild gegenüberstehen (Ajzen, 2005; vgl. auch Eagly \& Chaiken, 1998). Dabei wird die Einstellung der Umweltbildner(innen) von den erwarteten Konsequenzen der Leitbildarbeit (Verhaltensüberzeugungen) und ihrer Gewichtung der Konsequenzen (Bewertung der Verhaltensüberzeugungen) determiniert (Ajzen, 2005). Umweltbildner(innen), die eine zukünftige Leitbildarbeit mit positiv gewichteten Konsequenzen verbinden, werden 
demnach auch eine positive Einstellung gegenüber dieser besitzen (vgl. Ajzen, 2005; Frey, Stahlberg \& Gollwitzer, 2001).

Die Subjektive Norm gibt die individuelle Wahrnehmung sozialen Drucks durch wichtige Bezugspersonen an, die eine Orientierung am Leitbild befürworten oder ablehnen würden (Ajzen, 2005). Erwartungen von Personen an das Verhalten der Umweltbildner(innen) werden als Normüberzeugungen (2. Theorieebene, Abbildung 7) bezeichnet. Dabei gibt die Übereinstimmungsmotivation an, inwieweit die Umweltbildner(innen) bereit sind, den Erwartungen anderer zu entsprechen (Ajzen, 2005). Je größer die Neigung der Umweltbildner(innen) ist, dem wahrgenommenen sozialen Druck zu entsprechen, umso größer wird der Einfluss der subjektiven Norm auf eine Leitbildorientierung sein (vgl. Ajzen, 2005; Frey, Stahlberg \& Gollwitzer, 2001).

Die Wahrgenommene Verhaltenskontrolle als dritte Determinante einer Absicht, sich am Leitbild zu orientieren, bezieht sich auf die Leichtigkeit oder Schwierigkeit, welche die Umweltbildner(innen) mit einer Orientierung am Leitbild verbinden. Wahrgenommene Bedingungen, die eine Orientierung am Leitbild erleichtern oder erschweren können, werden als Kontrollüberzeugungen (2. Theorieebene, Abbildung 7) bezeichnet. Hierzu zählen beispielsweise wahrgenommene Ressourcen, die Einschätzung eigener Kompetenzen, aber auch das Verhalten anderer Personen. Die Wahrgenommene Verhaltenserleichterung/-erschwerung gibt eine Einschätzung der Umweltbildner(innen) zur Bedeutung von Kontrollüberzeugungen für eine Orientierung am Leitbild an (Ajzen, 2008, 2005). Je mehr Ressourcen, Kompetenzen und Verhaltensmöglichkeiten die Umweltbildner(innen) für eine zukünftige Leitbildarbeit glauben $\mathrm{zu}$ besitzen, umso größer wird der Einfluss der wahrgenommenen Verhaltenkontrolle auf ihre Absicht sein, sich zukünftig am Leitbild zu orientieren (vgl. ebd. ; Frey, Stahlberg \& Gollwitzer, 2001; Erten, 2000).

\section{Forschungsinteresse}

Ziel ist es herauszufinden, inwieweit die Umweltbildner(innen) beabsichtigen, nach ersten Erfahrungen in der Entwicklung und Erprobung ihres neuen Leitbildes zur Biodiversitätsbildung das Leitbild auch weiterhin zu berücksichtigen. Folgende Fragen sollen dabei untersucht werden. 
- Wie stehen die Umweltbilder(innen) einer Leitbildarbeit gegenüber? Welche Auswirkungen einer Orientierung am Leitbild nehmen die Umweltbildner(innen) wahr und wie gewichten sie diese?

- Inwieweit nehmen die Umweltbildner(innen) sozialen Druck wahr, sich am Leitbild $\mathrm{zu}$ orientieren? Welche wichtigen Bezugspersonen nehmen die Umweltbildner(innen) wahr, die eine Leitbildarbeit befürworten oder ablehnen würden? Wie stehen sie den Erwartungen der Personen gegenüber?

- Wie leicht oder schwer schätzen die Umweltbildner(innen) die Leitbildarbeit ein? Welche Bedingungen nehmen die Umweltbildner(innen) wahr, die eine Orientierung am Leitbild erleichtern oder erschweren können und wie gewichten sie diese?

Damit werden im Rahmen einer formativen Evaluation zu den relevanten Konstrukten der TOPB Erkenntnisse gewonnen.

\section{Methoden}

Um die Absichten der Umweltbildner(innen) in Bezug auf eine Fortführung der Leitbildarbeit identifizieren $\mathrm{zu}$ können, wurden problemzentrierte Einzelinterviews (Mayring, 2002) mit den vier zentral beteiligten Umweltbildner(inne)n durchgeführt. Einzelinterviews wurden eingesetzt, um den Umweltbildner(inne)n zu ermöglichen, ihre Erfahrungen bewusst zu reflektieren (in Anlehnung an Ajzen, 2005), offen individuelle Perspektiven und insbesondere persönliche Bedenken und wahrgenommene Probleme zu äußern (Mayring, 2002). Die Interviews fanden jeweils unmittelbar im Anschluss an drei Umsetzungen einer Veranstaltung mit dem/r durchführenden Umweltbilder(in) statt. Jedes Interview dauerte ca. 30-40 Minuten. In Anlehnung an die TOPB (Ajzen, 2005, 2008) wurde ein halbstrukturierter Interviewleitfaden (Tabelle 11) konzipiert. Der Leitfaden diente dazu, die Datenerhebung während der Interviewgespräche theoriegeleitet zu steuern (Bortz \& Döring, 2006). 
Tabelle 11. Auszug aus dem verwendeten Interviewleitfaden (in Anlehnung an die Theory of Planned Behavior TOPB; Ajzen, 2005, 2008)

\begin{tabular}{||ll||}
\hline \hline TOPB-KONSTRUKT & MÖGLICHE FRAGEN \\
\hline \hline & \\
$(\ldots)$ & $\ldots)$ \\
\hline \hline \multirow{3}{*}{ Einstellung } & Wie stehst du einer Orientierung am Leitbild bei der Entwicklung und \\
Verhaltensüberzeugungen & Durchführung von Veranstaltung gegenüber? \\
Bewertung der & Welche Auswirkungen hat es, sich bei der Entwicklung und \\
Verhaltensüberzeugungen & Durchführung von Veranstaltungen an den entwickelten Zielen, \\
& Teilzielen und Qualitätsmerkmalen des Leitbildes zu orientieren? \\
\hline \hline & Wie wichtig sind dir diese Auswirkungen? \\
Subjektive Norm & Inwieweit spielen Erwartungen anderer Personen eine Rolle, \\
Normüberzeugungen & Veranstaltungen nach dem Leitbild zu entwickeln und umzusetzen? \\
Übereinstimmungsmotivation & Wer sind die Erwartungsträger(innen) und welche Erwartungen haben \\
& sie? \\
& Inwieweit bist du dazu bereit, diese Erwartungen zu erfüllen? \\
\hline \hline Wahrgenommene & Wie leicht oder wie schwer fällt es dir, Veranstaltungen nach dem \\
Verhaltenskontrolle & Leitbild zu entwickeln und umzusetzen? \\
Kontrollüberzeugungen & Welche Bedingungen erschweren/erleichtern eine Orientierung am \\
Wahrgenommene & Leitbild bei der Veranstaltungsentwicklung und -umsetzung? \\
Verhaltenserschwerung/- & Wie wichtig sind diese Bedingungen für dich? \\
erleichterung & \\
\hline \hline (...) & (...) \\
\hline
\end{tabular}

Die Interviewgespräche wurden mit einem digitalen Diktiergerät aufgezeichnet und transkribiert (Mayring, 2002; siehe Anhang). Anschließend wurden die Daten redigiert: grammatische Satzfehlstellungen wurden bereinigt und Dialekte wurden ins Hochdeutsche überführt (vgl. Gropengießer, 2001). Zur Erhöhung der Objektivität des Vorgehens wurde das Redigieren der Redeabsätze von zwei Personen durchgeführt (siehe Stiel, 2007). Die Auswertung der Interviews erfolgt nach einem Auswertungsschema in Anlehnung an die Qualitative Inhaltsanalyse nach Mayring (2008) und Gropengießer (2001) ${ }^{11}$. In dieser Untersuchung wurde eine typisierendstrukturierende Analyseform verwendet (vgl. Mayring, 2008): In einem ersten Analyseschritt wurde ein Kategoriensystem erstellt. Die Kategorien wurden zunächst in 
Anlehnung an die TOPB (Ajzen, 2005, 2008) deduktiv erstellt und anschließend im Zuge der Zuordnung von Textstellen an die Kategorien induktiv ergänzt. Um eindeutige Zuordnungen von Textstellen zu Kategorien gewährleisten zu können, wurde jede Kategorie definiert und mit einem Ankerbeispiel versehen. Zusätzlich wurden für jede Kategorie Ausschlussregeln zur Abgrenzung ähnlicher Kategorien festgelegt. Die kodierten Textstellen stellten die Grundlage für einen Strukturierungsprozess dar, bei welchem die markanten Ausprägungen nach theoretischem Interesse (TOPB) herausgearbeitet wurden. Zur Erhöhung der Objektivität analysierter Daten wurde die Auswertung von zwei Personen durchgeführt (vgl. hierzu Stiel, 2007).

\section{Ergebnisse}

Im Folgenden werden die Ergebnisse der Analysen zusammengefasst vorgestellt. Um eine anonyme Darstellung der Umweltbildner(innen)aussagen zu gewährleisten, werden die Bezeichnungen UB1, UB2, UB3 und UB4 für die vier interviewten Umweltbildner(innen) verwendet.

Einstellung - Verhaltensüberzeugungen und Bewertung: UB2, UB3 und UB4 geben jeweils an, dass sie die Leitbildarbeit als wichtig und sinnvoll einschätzen. UB1 sagt aus, dass er/sie die Leitbildarbeit einerseits als wichtig beurteilt, ihr jedoch andererseits auch kritisch gegenübersteht: Die Umweltbildner(innen) geben jeweils an, dass das Leitbild eine wichtige Orientierungshilfe für die Planung und Umsetzung von Veranstaltungen darstellt. Eine Orientierung am Leitbild entspricht nach UB2 und UB4 einer systematischen, qualitätsentwickelnden und qualitätssichernden Arbeitsweise. Beide Umweltbildner(innen) befürworten diese Auswirkung. Klare Zielsetzungen des Leitbildes führen nach UB1 zu einem sicheren Umgang in der Umsetzung von Veranstaltungsinhalten und sind daher sinnvoll. UB2 gibt an, dass eine zentrale Funktion des Leitbildes ist, die Umweltbildner(innen) an die abgesprochenen Ziele zu erinnern. Hingegen betonen UB1, UB3 und UB4, dass eine Orientierung am Leitbild zu einer Profilbildung des Bildungsangebots in der Heinz Sielmann Stiftung führt. Die Umweltbildner(innen) bewerten diese Entwicklungen jeweils als wichtig.

Da das Leitbild kompetenzorientierte Vorgaben einer Bildung für Nachhaltige Entwicklung (vgl. Bormann \& de Haan, 2008; BMBF, 2002) und des Kerncurriculums Niedersachsen (vgl. Niedersächsisches Kultusministerium, 2007, 2008) betreffen, 
schätzen UB2 und UB3 die leitbildorientierte Gestaltung von Veranstaltungen als interessant für Schulklassen ein. Das ist nach UB1 wichtig für die Heinz Sielmann Stiftung.

UB2 gibt jedoch zu bedenken, dass eine Orientierung am Leitbild die „Kreativität“ der Umweltbildner(innen) bei der inhaltlichen Gestaltung von Veranstaltungen einschränkt. Nach UB1 ist eine Ansprache von Leitbildteilzielen mit einer Vermittlung von komplexen Zusammenhängen (vgl. z.B. Bögeholz \& Barkmann, 2003) verbunden. Das empfindet UB1 als ,anstrengend“ und „schnell ermüdend“. Im Sinne einer wertgebundenen, zukunftsorientierten Bildung ist nach UB1 die Vermittlung von Komplexität (ebd.) jedoch notwendig und richtig.

Subjektive Norm - Normüberzeugungen und Übereinstimmungsmotivation: Alle befragten Umweltbildner(innen) geben an, sozialen Druck wahrzunehmen, Veranstaltungen nach dem Leitbild zu entwickeln und umzusetzen. Sie geben alle jeweils an, dass sie Erwartungen der Mitarbeiter(innen) der Didaktik der Biologie wahrnehmen, sich am Leitbild zu orientieren. Nach UB1 tragen auch teilnehmende Schulklassen und Lehrer(innen) diese Erwartungshaltung. UB1, UB2 und UB4 geben zudem an, dass ihnen vorgesetzte Personen der Heinz Sielmann Stiftung sowie Mitarbeiter(innen) der Stiftung erwarteten, dass die Umweltbildner(innen) sich am Leitbild orientieren. Diese erhoffen sich eine zunehmende Qualitätsentwicklung des Bildungsangebotes der Stiftung. Zudem verbinden die Erwartungsträger eine Gestaltung von Veranstaltungen nach dem Leitbild mit finanziellen Fördermöglichkeiten. UB1 gibt an, Verständnis für diese Erwartung zu haben. Nach UB1 erhoffen sich manche Mitarbeiter(innen) der Stiftung, dass der Arbeitsaufwand für die Vorbereitung und Durchführung von Veranstaltungen nach dem Leitbild zukünftig geringer wird. Als weitere Erwartungsträger(innen) nennt UB1 die Umweltbildner(innen) selbst und nicht zuletzt Heinz Sielmann, welche eine Orientierung am Leitbild von ihm/ihr erwarten.

Die Umweltbildner(innen) geben eine grundsätzliche Bereitschaft an, die wahrgenommenen Erwartungen zu erfüllen. UB1 erläutert, dass vor allem bei den Kolleg(inn)en in der Heinz Sielmann Stiftung kein schlechter Eindruck entstehen soll. Hingegen erklärt UB4, dass er/sie Erwartungen nur solange erfüllen wird, wie er/sie eine Leitbildarbeit selbst als sinnvoll einschätzt. 
Wahrgenommene Verhaltenskontrolle - Kontrollüberzeugungen und wahrgenommene Verhaltenserleichterung: Alle befragten Umweltbildner(innen) geben an, dass eine Leitbildarbeit durch spezifische Bedingungen erschwert wird. Für die genannten Schwierigkeiten werden jedoch auch Lösungsvorschläge aufgezeigt. UB1, UB2 und UB4 erläutern zum einen, dass eine Orientierung am Leitbild erschwert wird, wenn die Umweltbildner(innen) sich nicht genügend mit den Leitbildzielen, insbesondere mit dem Ziel Systematisches Bewerten auseinandersetzen. UB1 und UB4 geben außerdem an, dass eigene Schwächen in der didaktisch-methodischen Aufbereitung (z.B. nach Helmke, 2009) von Veranstaltungen die Leitbildarbeit erschweren. Um diesen Schwierigkeiten entgegenzuwirken, schlägt UB1 vor, sich verstärkt mit dem Leitbild auseinanderzusetzen und mehr Erfahrung in der Umsetzung des Leitbilds zu sammeln. UB1 und UB4 schlagen eine gemeinsame Gestaltung von Leitbildveranstaltungen im Kreis der Umweltbildner(innen) auch nach der wissenschaftlichen Begleitung vor. Zudem können laut UB2 und UB4 kontinuierliche Fortbildungen zur Gestaltung von Bildungsmaßnahmen eine Orientierung am Leitbild erleichtern. Die genannten Bedingungen sowie Lösungsvorschläge schätzen UB1, UB2 und UB4 als bedeutsam ein. UB2 erklärt, es sei notwendig, die Anzahl zu erfüllender Qualitätsmerkmale für eine Veranstaltung auf ein Minimum zu reduzieren, um sich in Umsetzungen angemessen auf den jeweiligen Veranstaltungsfokus konzentrieren zu können.

Als erschwerende Bedingungen werden je Umweltbildner(in) zum anderen Personalmangel in der Stiftung, fehlende Räumlichkeiten und mangelnde Zeitkapazitäten genannt. Die Umweltbildner(innen) schätzen die Schwierigkeiten jedoch als lösbar ein. UB1 erläutert zunächst, dass für Veranstaltungsdurchführungen Räume im Stiftungsgebäude bereitgestellt werden müssen, in denen Schulklassen angemessen lernen können. Um die Leitbildarbeit zu erleichtern, geben UB1 und UB4 zudem an, dass durch eine Verstärkung des Personals im Bereich Umweltbildung Zeitressourcen freiwerden würden, die für die Umsetzung des Leitbildes genutzt werden könnten. Eine Bereitstellung von mehr Zeit für die Vorbereitung und Durchführung von Leitbildveranstaltungen als den Umweltbildner(inne)n bislang zur Verfügung steht, wäre nach UB2 und UB4 für eine leitbildbasierte Biodiversitätsbildung ebenfalls sinnvoll. Um vorhandene Zeitkapazitäten effizient zu nutzen, schlägt UB3 eine intensive Zusammenarbeit und eine Arbeitsteilung unter den Umweltbildner(inne)n vor. 
UB1, UB2 und UB3 geben zudem an, dass es für Schulklassen zukünftig schwierig werden könnte, an den Veranstaltungen der Stiftung teilzunehmen. Diese Annahme begründet UB2 mit steigenden Transportkosten und geringer Unterrichtszeit, welche Schulklassen für einen Besuch außerschulischer Lernorte zur Verfügung steht. Diese Entwicklung ist nach UB2 und UB3 ernst zu nehmen. Um diesen Bedingungen entgegenzuwirken, schlägt UB2 vor, zukünftig mehrere Schulklassen gleichzeitig in der Stiftung aufzunehmen. So könnten Transportkosten gespart werden. UB2 zweifelt jedoch, ob ein solcher Vorschlag realisiert werden kann. UB1 und UB3 geben zu bedenken, dass eine Zusammenarbeit von Umweltbildner(inne)n und Lehrer(inne)n zur angemessenen Verzahnung von Bildungsangeboten nach dem Leitbild mit Schulunterricht den Schulklassen eine Teilnahme erleichtern könnte.

\section{Diskussion}

Im Folgenden werden zunächst die Erkenntnisse im Hinblick auf die Konstrukte der TOPB diskutiert. Je Konstrukt werden anschließend Handlungsempfehlungen vorgestellt, die im Sinne einer formativen Evaluation dazu beitragen sollen, potentiellen Barrieren der Leitbildarbeit entgegenzuwirken.

In Anlehnung an Ajzen $(2005,2008)$ ist eine Absicht, in diesem Fall sich weiterhin am Leitbild orientieren zu wollen, der zentrale Prädiktor für eine tatsächliche Fortführung der Leitbildarbeit. Die Absichten der Umweltbildner(innen) werden nach Ajzen (2005, 2008) von deren Einstellung, ihrer subjektiven Norm und ihrer wahrgenommenen Verhaltenskontrolle determiniert. Im Hinblick auf die Einstellung der Umweltbildner(innen) konnte festgestellt werden, dass sie eine Leitbildarbeit überwiegend positiv bewerten. Lediglich UB1 äußert sich auch skeptisch. Eine Analyse von Verhaltensüberzeugungen der Umweltbildner(innen) zeigte, dass zum einen Ziele der Leitbildarbeit in der Heinz Sielmann Stiftung, wie z.B. Kompetenzorientierung im Sinne einer Bildung für Nachhaltige Entwicklung (z.B. Bormann \& de Haan, 2008; BMBF, 2002) und ein Einbezug curricularer Vorgaben (KMK, 2005; Niedersächsisches Kultusministerium, 2007, 2008) ihrer positiven Einstellung zu Grunde liegen. Die Umweltbildner(innen) geben zum anderen potentielle Funktionen eines Leitbildes (vgl. Giesel, 2007) an: z.B. das Leitbild als Orientierungshilfe, als Erinnerung an Abgesprochenes sowie als profilbildend für das Bildungsangebot der Stiftung. Die 
Auswirkungen werden von den Umweltbildner(inne)n positiv gewichtet. Sie tragen somit einer positiven Einstellung gegenüber einer zukünftigen Leitbildarbeit bei und fördern die Absicht der Umweltbildner(innen), sich am Leitbild zu orientieren (vgl. Ajzen, 2005).

Eine Orientierung am Leitbild stellt eine neue Herausforderung für die Umweltbildner(innen) dar. Die gezielte, systematische Arbeitsweise ist nach UB1 anstrengend. Die Anstrengungen bewertet UB1 jedoch als gerechtfertigt, sodass ein negativer Einfluss dieser Verhaltensüberzeugung auf die Einstellung von UB1 eher unwahrscheinlich ist (vgl. Ajzen, 2005). Hingegen erklärt UB2, dass die Leitbildarbeit die „Kreativität“ der Umweltbildner(innen) einschränkt. Diese Einschätzung lässt sich dadurch erklären, dass die Umweltbildner(innen) bislang Veranstaltungen zu einem großen Anteil eigenverantwortlich, selbst gesteuert und nach eigenen Interessensgebieten entwickelten und umsetzten. Durch die Leitbildarbeit sind nun konkrete Ziele in Bildungsmaßnahmen zu erfüllen (vgl. Giesel, 2007). Die inhaltliche Umsetzung der Ziele bleibt jedoch nach wie vor den Umweltbildner(inne)n überlassen, so dass die „Kreativität“ der Umweltbildner(innen) weiterhin von zentraler Bedeutung für die Gestaltung von Bildungsveranstaltungen ist. UB2 gibt keine Gewichtung zu dieser Überzeugung an, sodass eine Aussage über den Einfluss der Verhaltensüberzeugung auf die Einstellung von UB2 an dieser Stelle offen bleibt.

Im Hinblick auf die kritischen Beiträge von UB1 und UB2 soll in Box 1 der Versuch unternommen werden, Möglichkeiten aufzuzeigen, wie eine positive Einstellung der Umweltbildner(innen) gegenüber dem neuen Leitbild gefördert werden kann.

Eine positive Einstellung der Umweltbildner(innen) könnte gefördert werden, indem sie mehr Erfahrung in der Entwicklung und Umsetzung von Veranstaltungen nach dem Leitbild sammeln. Die Umweltbildner(innen) könnten durch die Einübung der Umsetzung neuer Bildungsziele einen flexibleren, routinierteren und somit weniger ,,anstrengenden“ (UB1) Umgang mit dem Leitbild erfahren. Gleichzeitig könnte ein vermehrtes Kompetenzerleben dazu beitragen, dass die Umweltbildner(innen) erkennen, dass, obwohl das Leitbild eine eindeutige Zielrichtung zur Gestaltung von Bildungsangeboten vorgibt (vgl. Giesel 2007), eine didaktisch-methodische Gestaltung der Ziele der „Kreativität“ der Umweltbildner(innen) (vgl. UB2) überlassen ist.

Box 1. Handlungsempfehlung zur Förderung einer positiven Einstellung der Umweltbildner(innen) 
In Bezug auf die subjektive Norm der Umweltbildner(innen) konnte festgestellt werden, dass Erwartungen anderer eine Rolle spielen. Besonders viele Erwartungsträger nimmt UB2 wahr. Am häufigsten werden die Mitarbeiter(innen) der Didaktik der Biologie und der Vorstand der Heinz Sielmann Stiftung als Erwartungsträger(innen) genannt. Um eine Fortführung der Leitbildarbeit zu beabsichtigen, müssen die Umweltbildner(innen) die wahrgenommenen Erwartungen erfüllen wollen (Ajzen, 2005). Eine Bereitschaft geben UB1 und UB3 an. Hingegen ist die eingeschränkte Haltung von UB4 erneut dadurch zu erklären, dass den Umweltbildner(inne)n bislang ein großer Entscheidungsund Handlungsfreiraum für die Gestaltung von Bildungsveranstaltungen zur Verfügung stand. Eine Einschränkung des Freiraums durch konkrete Zielvorgaben des Leitbildes akzeptiert UB4 somit nur bedingt. Entsprechend ist anzunehmen, dass die subjektive Norm bei UB4 seine/ihre Absicht senkt, sich am Leitbild zu orientieren.

In Box 2 werden mögliche Handlungsempfehlungen aufgezeigt, welche die subjektive Norm der Umweltbildner(innen) und somit ihre Absicht, sich am Leitbild zu orientieren, fördern könnten. Dabei sind Handlungsempfehlungen bedeutsam, welche die Bereitschaft der Umweltbildner(innen), dem sozialen Druck zu entsprechen (Übereinstimmungsmotivation nach Ajzen, 2005), fördern.

Um die subjektive Norm der Umweltbildner(innen) zu erhöhen, kann die Kommunikation sowohl innerhalb der Stiftung als auch mit externen Beteiligten (Schule) bedeutsam sein. Klare Absprachen erhöhen die Verbindlichkeit der Umweltbildner(innen), auch zukünftig Veranstaltungen nach dem Leitbild zu gestalten (vgl. z.B. Gräsel \& Parchmann, 2004).

- Sowohl die Umweltbildner(innen) untereinander, als auch Mitarbeiter(innen) und Vorgesetzte der Umweltbildner(innen) in der Stiftung sollten Ihre Erwartungen explizit darstellen und begründen.

- Die Umweltbildner(innen) sollten Erwartungen von Lehrkräften an eine Biodiversitätsbildung - insbesondere zur Passung für Unterricht - identifizieren und in die Leitbildarbeit integrieren.

Box 2. Handlungsempfehlung zur Erhöhung der subjektiven Norm bei Umweltbildner(inne)n 
In der Untersuchung zur Wahrgenommenen Verhaltenskontrolle (Ajzen, 2008, 2005) konnte gezeigt werden, dass die Umweltbildner(innen) die Leitbildarbeit als schwierig einschätzen. Als erschwerende Bedingungen nehmen sie zum einen mangelnde eigene Kompetenzen wahr. Hierbei werden sowohl Schwierigkeiten in Bezug auf den Umgang mit einzelnen Leitbildzielen, insbesondere dem Ziel Systematisches Bewerten als auch Schwächen in Bezug auf leitbildunabhängige Kompetenzen wie der didaktischmethodischen Aufbereitung von Bildungsveranstaltungen (z.B. Helmke, 2009) genannt. Um eine leitbildbasierte Biodiversitätsbildung zu erleichtern, muss ein kompetenter Umgang mit dem Leitbild gefördert werden. Die Umweltbildner(innen) geben hierzu selbst Vorschläge (siehe oben) an, die in Box 3 aufgegriffen werden.

Problematisch für eine zukünftige Leitbildarbeit sind jedoch solche wahrgenommenen Bedingungen, die nicht direkt von den Umweltbildner(inne)n gesteuert werden können (vgl. Ajzen, 2005). Sowohl genannte organisatorische Rahmenbedingungen (z.B. Personalmangel, fehlende Veranstaltungsräume usw.) als auch eine befürchtete sinkende Teilnahme von Schulklassen zählen hierzu. Sie unterliegen nicht dem Kontrollbereich der Umweltbildner(innen) (ebd.). Um eine zukünftige Leitbildarbeit zu fördern, sind daher zum einen Absprachen und eine Umsetzung verhaltenserleichternder Bedingungen innerhalb der Stiftung notwendig. Zum anderen kann eine enge Verzahnung von außerschulischen Bildungsangeboten mit Schulunterricht hilfreich sein. Hierfür müssen Umweltbildner(innen) und Lehrer(innen) gemeinsam eine Zusammenarbeit planen, umsetzen und - im Idealfall - reflektieren und optimieren. In Box 4 werden entsprechende Handlungsempfehlungen zusammengefasst. Eigene Vorschläge der Umweltbildner(innen) (siehe oben) wurden in der Darstellung berücksichtigt. 
Einen kompetenteren Umgang mit dem Leitbild können die Umweltbildner(innen) dadurch erwerben, indem sie

- sich intensiv mit dem Leitbild auseinandersetzen und das gemeinsame Verständnis von Zielen, Teilzielen und Qualitätsmerkmalen des Leitbildes klären,

- zunächst nur eine geringe Anzahl von Qualitätsmerkmalen in Veranstaltungen gezielt ansprechen, um Vertrautheit in der Umsetzung des Leitbildes zu entwickeln,

- mehr Erfahrungen in der gemeinsamen Entwicklung und Umsetzung des Leitbildes sammeln und somit mehr Sicherheit in der Arbeit mit dem Leitbild gewinnen und

- je nach Bedarf kontinuierlich an Fortbildungen zur didaktisch-methodischen Gestaltung von Bildungsmaßnahmen teilnehmen.

Box 3. Handlungsempfehlungen zur Erhöhung wahrgenommener eigener Kompetenzen bei Umweltbildner(inne)n

Um eine Orientierung am Leitbild $\mathrm{zu}$ erleichtern, sind organisatorische Absprachen und Regelungen innerhalb der Stiftung bedeutsam. Dies betrifft Fragen nach

- Personal zur Gestaltung von Bildungsveranstaltungen nach dem Leitbild.

- Zeitressourcen und Räumen für leitbildbasierte Bildungsveranstaltungen.

- Möglichkeiten zur intensiven arbeitsteiligen Zusammenarbeit der Umweltbildner(innen) untereinander.

Um eine zukünftige Teilnahme von Schulklassen an Veranstaltungen nach dem Leitbild zu erleichtern, sollten

- Maßnahmen zur Reduzierung von Transportkosten für Teilnehmer(innen) eruiert werden.

- Konkrete Absprachen mit Lehrer(inne)n teilnehmender Schulklassen zur Verzahnung außerschulischer Bildungsangebote nach dem Leitbild mit Schulunterricht getroffen werden.

Box 4. Handlungsempfehlungen zur Verhaltenserleichterung von Bedingungen, die nicht der direkten Kontrolle der Umweltbilder(innen) unterliegen 
Da die Umweltbildner(innen) alle genannten erschwerenden Bedingungen allgemein als lösbar (kontrollierbar) einschätzen sowie konkrete Lösungsvorschläge angeben, ist anzunehmen, dass der negative Beitrag erschwerender Bedingungen für die Absicht der Umweltbildner(innen), sich weiterhin am Leitbild zu orientieren, eher gering ist (vgl. Ajzen, 2008, 2005; Frey, Stahlberger \& Gollwitzer, 2001) und überwunden werden kann. Von zentraler Bedeutung für eine zukünftige Förderung der wahrgenommenen Verhaltenskontrolle der Umweltbildner(innen) wird es daher sein, an den aufgezeigten Handlungsempfehlungen (Box 3 und 4) anzusetzen.

\section{Kritische Betrachtung des theoriegeleiteten methodischen Vorgehens}

Eine Untersuchung subjektiver Einschätzungen ist im Rahmen einer formativen Evaluation der Leitbildarbeit in der Heinz Sielmann Stiftung zentral. Durch einen Einsatz der TOPB (Ajzen, 2008, 2005) können Hinweise auf Probleme in der Leitbildarbeit aus der Perspektive der Praktiker(innen) theoriegeleitet identifiziert und dazu genutzt werden, Handlungsmöglichkeiten zur Optimierung abzuleiten (z.B. Giesel, 2007; Schratz, 2003). Durch Untersuchung der Absicht der Umweltbildner(innen), sich am Leitbild zu orientieren, ihrer Einstellung, subjektiven Norm und Wahrgenommenen Verhaltenskontrolle ist es weitgehend möglich abzuschätzen, inwieweit sich die Umweltbildner(innen) tatsächlich am Leitbild orientieren werden (Ajzen, 2005, 2008). Dabei bieten problemzentrierte Einzelinterviews den Umweltbildner(inne)n die Möglichkeit, ihre Erfahrungen bewusst zu reflektieren und Einschätzungen, Bedenken und Wünsche offen zu äußern (vgl. Mayring, 2002; auch Reinmann-Rothmeier \& Mandl, 1998). Eine Datenauswertung durch zwei Personen trägt zudem dazu bei, die Objektivität des methodischen Vorgehens zu erhöhen (Mayring, 2008).

Dennoch birgt das Vorgehen auch Schwächen, die im Hinblick auf die gewonnenen Ergebnisse und abgeleiteten Schlussfolgerungen berücksichtigt werden müssen. Zum einen ist fraglich, ob mit der TOPB (Ajzen, 2008, 2005) bereits alle relevanten Einflüsse auf eine leitbildbasierte Biodiversitätsbildung untersucht werden konnten. Anlass zu dieser Vermutung geben Ergebnisse aus Studien (z.B. Beck \& Ajzen, 1991; Okun \& Sloane, 2002), die weitere verhaltensbeeinflussende Parameter identifizierten bzw. feststellten, dass weitere Parameter eine Rolle spielen müssen (vgl. hierzu auch Erten, 2000). Zum anderen ist unklar, inwieweit - in Anbetracht der Stiftungsarbeit als 
dynamisches System - ungeplante, unvorhersehbare Ereignisse einen Einfluss auf eine zukünftige Leitbildarbeit haben können. Schließlich kann mit der TOPB lediglich bewusst geplantes Verhalten untersucht werden (Ajzen, 2005). Durch den Einsatz der Theorie kann daher letztlich nicht vollständig geklärt werden, inwieweit eine zukünftige Leitbildarbeit tatsächlich erfolgen wird (vgl. u. a. Frey, Stahlberg \& Gollwitzer, 2001). Neben Fragen an die theoretisch basierte Reichweite der Untersuchung sind auch Schwächen in der methodischen Vorgehensweise zu benennen. Durch den Einsatz problemzentrierter Einzelinterviews (Mayring, 2002) können sozial erwünschte Antworttendenzen bei Umweltbildner(inne)n nicht ausgeschlossen werden. Um ein möglichst positives Bild von sich selbst $\mathrm{zu}$ zeichnen, neigen Befragte dazu, Antworten »zu verzerren«. Dies kann sowohl bewusst als auch unbewusst geschehen (vgl. Frey, Stahlberg \& Gollwitzer, 2001). An dieser Stelle bleibt unklar, inwieweit die gegebenen Antworten vollständig den tatsächlichen Einschätzungen der Umweltbildner(innen) entsprechen.

\section{Fazit}

Die vorliegende Studie stellt einen qualitativen Beitrag zur Anwendung der Theory of Planned Behavior (Ajzen, 2005) dar. Der Einsatz der Theorie bietet eine Möglichkeit, weitgehend einzuschätzen, inwieweit eine Leitbildarbeit von den Umweltbildner(inne)n zum Zeitpunkt der Interviewführung bewusst und überlegt intendiert wird. Die Analysen konnten zeigen, dass die Umweltbildner(innen) überwiegend beabsichtigen, zukünftig Veranstaltungen nach dem Leitbild zu gestalten. Sie haben eine überwiegend positive Einstellung zum Leitbild, sie nehmen sozialen Druck wahr, sich zukünftig am Leitbild $\mathrm{zu}$ orientieren und glauben überwiegend, Bedingungen für eine zukünftige Umsetzung des Leitbildes kontrollieren zu können. Eine zukünftige Leitbildarbeit ist daher wahrscheinlich (vgl. Ajzen, 2005, 2008). Aufgezeigte Handlungsempfehlungen können zusätzlich dazu beitragen, die Absicht der Umweltbildner(innen), sich zukünftig am Leitbild zu orientieren, zu bestärken.

Nicht geklärt werden kann, inwieweit nicht vorhersagbare, ungeplante Gegebenheiten eine zukünftige Leitbildarbeit dennoch gefährden können. Hier stößt die Reichweite der Theorie an ihre Grenzen (vgl. Frey, Stahlberg \& Gollwitzer, 2001). Fraglich bleibt auch, inwieweit problemzentrierte Einzelinterviews (Mayring, 2002) angemessene Unter- 
suchungsinstrumente zur Analyse von Verhaltensabsichten darstellen. Die Untersuchung liefert dennoch bedeutsame Hinweise, die im Rahmen einer formativen Evaluation (vgl. Wottawa \& Thierau, 2003) von zentraler Bedeutung sind, um die weitere Gestaltung innovativer leitbildbasierter Bildungsangebote zu optimieren. 
5.3 Teilstudie 3: Bewertungskompetenz in der reflexiven Leitbildarbeit eines Umweltbildungszentrums - Ein Beitrag zur Professionalisierung des pädagogischen Personals ${ }^{12}$

Für eine Vermittlung von Bewertungskompetenz sind neben dem Schulunterricht Lernangebote außerschulischer Lernorte zentral. Um außerschulisch Bewertungskompetenz zu fördern, haben Umweltbildner(innen) und Biologiedidaktiker(innen) gemeinsam ein Leitbild (Giesel, 2007) zur Biodiversitätsbildung unter besonderer Berücksichtigung des Kompetenzbereichs Bewertung (KMK, 2005; Niedersächsisches Kultusministerium, 2008, 2007) entwickelt. Nach einer einjährigen Erprobungsphase leitbildbasierter Bildungsveranstaltungen reflektiert die Arbeitsgruppe aus Praxis und Wissenschaft im Zuge einer reflexiven Leitbildarbeit (vgl. Giesel, 2007) in einer Fokusgruppe (Morgan, 1998) die inhaltliche Kohärenz des Leitbildes und die Qualität der Umsetzungen der leitbildbasierten Veranstaltungen zur Vermittlung von Bewertungskompetenz. Der Artikel plädiert erstens für eine Unterstützung der schulischen Vermittlung von Bewertungskompetenz durch außerschulische leitbildbasierte Lernangebote. Zweitens betont der Artikel das Erfordernis reflexiver Leitbildarbeit und damit einer fortwährenden kritische Überprüfung und Weiterentwicklung des Leitbildes und dessen Umsetzbarkeit in der Bildungspraxis (Giesel, 2007).

Fostering decision-making competence is a central task of German biology education (KMK, 2005). Beside school education extra-curricular education centres play a central role for teaching decision-making competence. Educators working at an education centre and researchers in biology education developed a Leitbild (Giesel, 2007) for innovative courses on biodiversity education, especially on socio-scientific decision making (KMK, 2005; Niedersächsisches Kultusministerium, 2008, 2007). According to the Leitbild they developed and tested new courses. After one year of practical experience, the working group critically proofed the Leitbild's content coherence and the quality of its application in order to improve teaching interventions. For this reflexive Leitbild work (according to Giesel, 2007) a focus group (Morgan, 1998) was applied. The article firstly argues for the role of Leitbild-based extra-curricular courses

\footnotetext{
${ }^{2}$ Manuskript eingereicht zur Publikation in einer wissenschaftlichen Zeitschrift.
} 
for teaching socio-scientific decision-making. Secondly, it emphasises the importance of reflexive Leitbild work and thus continuous reflecting and improving the Leitbild and its application in educational practice (Giesel, 2007).

\section{Einleitung}

Ein zentraler Anforderungsbereich der Bildungsstandards für das Fach Biologie ist der Kompetenzbereich Bewertung (Kultusministerkonferenz [KMK], 2005; Niedersächsisches Kerncurriculum, 2007, 2008). Schüler(innen) sollen „Biologische Sachverhalte in verschiedenen Kontexten erkennen und bewerten “ lernen (KMK, 2005, 14). Hierfür sollen sie unter anderem „Zwischen beschreibenden (naturwissenschaftlichen) und normativen (ethischen) Aussagen [unterscheiden] “, „Auswirkungen menschlicher Eingriffe in einem Ökosystem [beschreiben und beurteilen]“ und „Handlungsoptionen einer umwelt- und naturverträglichen Teilhabe im Sinne der Nachhaltigkeit [erörtern] “ können. Nach Bögeholz $(2007,209)$ ist unter Bewertungskompetenz $\mathrm{zu}$ verstehen: „die Fähigkeit, sich in komplexen Problemsituationen begründet und systematisch bei unterschiedlichen Handlungsoptionen zu entscheiden“, um beispielsweise am gesellschaftlichen Diskurs um eine Nachhaltige Entwicklung unseres Planeten teilhaben $\mathrm{zu}$ können. Charakteristisch für derartige komplexe Problem- und Entscheidungssituationen ist, dass sie keine eindeutige, sondern vielmehr mehrere - auch gleichwertige - Lösungen aufweisen können (Eggert \& Bögeholz, 2006). Zukunftsfähige Lösungsansätze müssen dabei, gemäß dem Leitbild der Nachhaltigen Entwicklung, sowohl ökologische als auch ökonomische und soziale Aspekte berücksichtigen (ebd.; Bögeholz, Bittner \& Knolle, 2006; de Haan, 2006). Des Weiteren müssen geeignete Lösungsansätze (= Handlungsoptionen) miteinander verglichen werden, um $\mathrm{zu}$ einer begründeten Entscheidung zu gelangen. Dabei ist eine Anwendung von Entscheidungsstrategien zentral. Die Kenntnis von Entscheidungsstrategien kann Schüler(innen) in einem systematischen Vergleich von Handlungsoptionen unterstützen. Die Vermittlung von Entscheidungsstrategien kann dabei durch außerschulische Lernangebote unterstützt werden (vgl. Wilson \& Monroe, 2005).

In Niedersachsen haben sich die Regionalen Umweltbildungszentren (RUZ) explizit dazu verpflichtet, Unterricht zu unterstützen (Niedersächsisches Kultusministerium, 
2006). Eines der Regionalen Umweltbildungszentren ist beispielsweise die Heinz Sielmann Stiftung ${ }^{13}$. Ihre Mitarbeiter(innen) und Biologiedidaktiker(innen) haben nach dem symbiotischen Implementationsansatz (Gräsel \& Parchmann, 2004) ein innovatives Leitbild (Giesel, 2007) mit Zielen, Teilzielen und Qualitätsmerkmalen für die Bildungsarbeit der Stiftung entwickelt. Das Leitbild hat als einen zentralen Fokus die Förderung von Bewertungskompetenz. Entsprechend dem Naturschutzanliegen der Heinz Sielmann Stiftung fokussiert das Leitbild auf Bewertungskompetenz zum Schutz und der Nachhaltigen Nutzung von Biodiversität. Basierend auf dem neuen Leitbild entwickelte die Arbeitsgruppe aus Praktiker(inne)n und Wissenschaftler(inne)n gemeinsam vier prototypische Veranstaltungen - jeweils eine Veranstaltung für jede Jahreszeit, aufbereitet für Schulklassen der Sekundarstufe I und II. Die Kurse wurden im Laufe eines Jahres mehrmals auf dem Gelände der Heinz Sielmann Stiftung erprobt und formativ evaluiert. Um gewonnene Erfahrungen $\mathrm{zu}$ reflektieren, führte die Arbeitsgruppe nach Entwicklung und Umsetzung aller neuen leitbildbasierten Veranstaltungen eine Fokusgruppe, ein Gruppeninterview (Morgan, 1998), durch. In diesem Artikel werden die Ergebnisse dieser Fokusgruppe vorgestellt und diskutiert. Es wird aufgezeigt, wie die Umweltbildner(innen) eine außerschulische Arbeit zu Bewertungskompetenz erfahrungsbasiert einschätzen und wie sie die Erkenntnisse für ihre zukünftige Bildungspraxis zu nutzen beabsichtigen. Die Ergebnisse dienen zum einen dazu, das gemeinsam entwickelte Leitbild und dessen Umsetzung zu optimieren. Zum anderen liefern sie Hinweise, die zur Weiterentwicklung der Theorie zur Leitbildarbeit genutzt werden können.

\section{Theoretischer Hintergrund und Stand der Forschung}

In Zusammenarbeit von Wissenschaft und Praxis wurde im Rahmen einer formativen Evaluation ein Leitbild (Giesel, 2007) zur Biodiversitätsbildung unter besonderer Berücksichtigung des Kompetenzbereichs Bewertung (KMK, 2005) für die Heinz Sielmann Stiftung erarbeitet. Das Leitbild bietet den inhaltlichen Orientierungsrahmen für eine zielgerichtete Steuerung bei der Entwicklung und Umsetzung von

${ }^{3}$ Die Heinz Sielmann Stiftung wurde 1994 von dem Tierfilmer Heinz Sielmann und seiner Frau, Inge Sielmann, in Duderstadt bei Göttingen gegründet. Seit 2004 ist die Stiftung ein Regionales Umweltbildungszentrum. 
Veranstaltungen zur Bewertung von Maßnahmen zum Schutz und für eine Nachhaltige Nutzung von Biodiversität (Niedersächsisches Kerncurriculum, 2008, 2007). Das Leitbild soll dazu dienen, die Umweltbildner(innen) zu motivieren, sich konstruktiv an der Qualitätsentwicklung im Bildungsbereich der Stiftung zu beteiligen und sich durch ein eindeutiges Profil von anderen Bildungsanbietern abzuheben. Ein Leitbild kann eine verbesserte Kooperation der Umweltbildner(innen) untereinander ermöglichen und somit zu einem effizienten Zusammenarbeiten beitragen (Conein, 2000; Giesel, 2007; Kempfert \& Rolff, 2005).

Angelehnt an Conein (2000) fasst das Leitbild der Heinz Sielmann Stiftung Ziele und Teilziele, die zentral für eine Biodiversitätsbildung sind. Insgesamt wurden acht Ziele für das Leitbild definiert. Der Kompetenzbereich Bewertung (KMK, 2005) wurde dabei mit dem Ziel Systematisches Bewerten (Bögeholz, 2006a) in dem neuen Leitbild aufgegriffen. Für eine Überprüfung und ggf. Optimierung der Erfüllung von Leitbildzielen wurden Qualitätsmerkmale definiert (Schratz, 2003). Entgegen Coneins (2000) Definition eines Leitbildes, wird das Leitbild zur Biodiversitätsbildung der Heinz Sielmann Stiftung als nicht statisch verstanden. Vielmehr sind - insbesondere im Rahmen einer qualitätsentwickelnden, formativen Evaluation - eine fortwährende Reflexion und Revision des Leitbildes zentrale Schritte einer reflexiven (und damit kontinuierlichen) Leitbildarbeit (Abbildung 8; vgl. auch Giesel, 2007). Somit ist ein zyklisches Vorgehen bei der Leitbildarbeit vorgesehen. In dieser Studie wird Coneins Leitbildkonzept (Leitbildbausteine und -funktionen; Conein, 2000) daher um den zyklischen Prozess einer reflexiven Leitbildarbeit ergänzt (Abbildung 8).

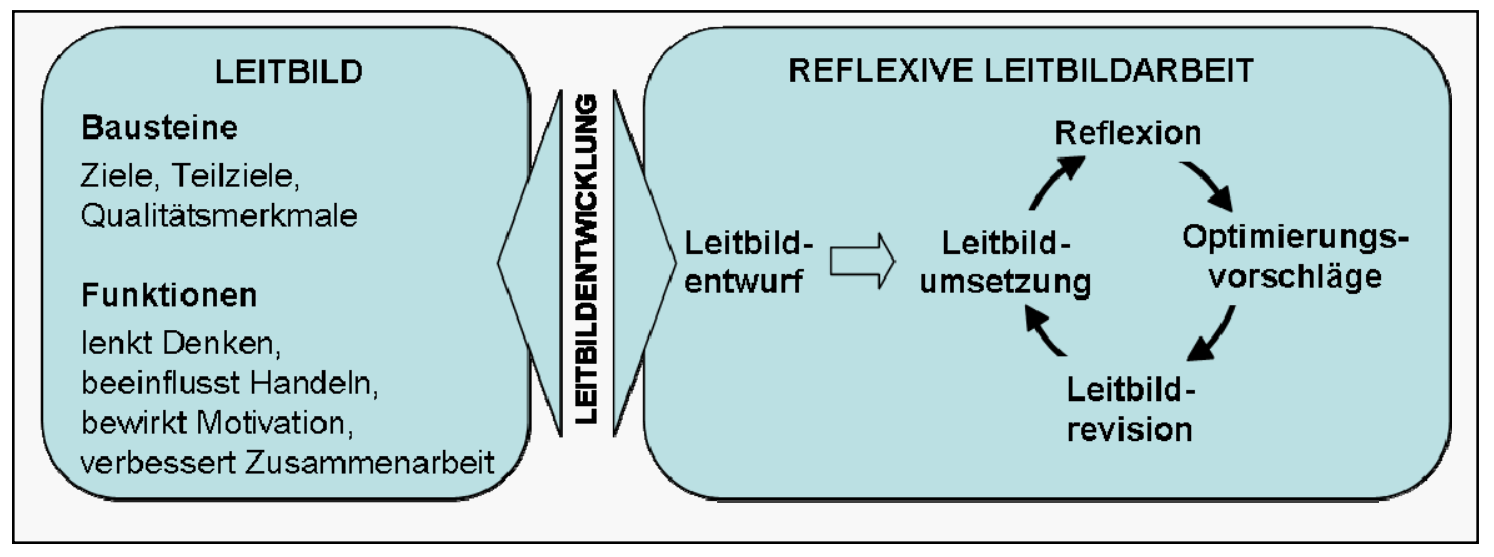

Abbildung 8. Kontinuierliche Leitbildarbeit zur Verstetigung einer formativen Evaluation 
Durch Umsetzung des Leitbildzielbereichs Systematisches Bewerten sollen Schüler(inne)n Kompetenzen vermittelt werden, die es ihnen ermöglichen, tragfähige Entscheidungen zum Schutz und zur Nachhaltigen Nutzung von Biodiversität zu treffen. Theoretische Grundlage hierfür bildet das Göttinger Modell der Bewertungskompetenz (Bögeholz, 2007; Eggert \& Bögeholz, 2006). Dieses Modell umfasst vier Teilkompetenzen. Schüler(innen) sollen zum einen geeignete Handlungsoptionen in Bewertungssituationen unter Berücksichtigung relevanter Sachinformationen generieren und reflektieren können, und damit ein Sachmodell für die Bewertungssituation aufstellen (Teilkompetenz 3). Zum anderen müssen Schüler(innen) die entwickelten Handlungsoptionen (unter Anwendung einer Entscheidungsstrategie) miteinander vergleichen, und damit ein Bewertungsmodell für die gegebene Bewertungssituation aufstellen (Teilkompetenz 4). Des Weiteren müssen Schüler(innen) über Wissen um relevante Werte und Normen (Teilkompetenz 2, vgl. auch Bögeholz \& Barkmann, 2004) sowie ein Verständnis über das Konzept der Nachhaltigen Entwicklung verfügen (Teilkompetenz 1). Das Modell wurde für die Biodiversitätsbildung der Heinz Sielmann Stiftung kontextualisert. Somit bezieht sich die erste Teilkompetenz auf ein Kennen und Verstehen von biologischer Vielfalt. Tabelle 12 zeigt das Leitbildziel Systematisches Bewerten mit seinen Teilzielen und Qualitätsmerkmalen.

Tabelle 12. Systematisches Bewerten - Zielbereich des Leitbildes zur Biodiversitätsbildung der Heinz Sielmann Stiftung

\begin{tabular}{|c|c|c|}
\hline ZIEL & $\begin{array}{l}\text { TEILZIELE } \\
\text { Die Veranstaltung zielt auf.. }\end{array}$ & $\begin{array}{l}\text { QUALITÄTSMERKMALE ZUR BEURTEILUNG } \\
\text { DER ZIELERFÜLLUNG Die Umweltbildner(innen)... }\end{array}$ \\
\hline 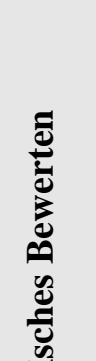 & $\begin{array}{l}\text { - eine theoriegeleitete Umset- } \\
\text { zung des Kompetenzbereichs } \\
\text { Bewertung anhand des Modells } \\
\text { der Bewertungskompetenz } \\
\text { (Bögeholz, 2006a, Eggert \& } \\
\text { Bögeholz, 2006). }\end{array}$ & $\begin{array}{l}\text { - ermöglichen Lernphasen, welche Teilkompetenzen } \\
\text { des Modells der Bewertungskompetenz abdecken: } \\
\text { - Sachmodelle entwickeln und kritisieren. } \\
\text { - Normen und Werthaltungen auf Sachwissen beziehen. } \\
\text { - Bewertungsmodelle entwickeln (Auswahl, } \\
\text { Gewichtung, Verknüpfung) und kritisch prüfen. }\end{array}$ \\
\hline 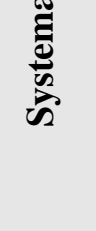 & $\begin{array}{l}\text { - ein Erkennen eigener und } \\
\text { fremder Werthaltungen sowie } \\
\text { relevanter Normen (Bögeholz \& } \\
\text { Barkmann, 2004). }\end{array}$ & $\begin{array}{l}\text { - schaffen Situationen, in denen eigene und fremde } \\
\text { Werthaltungen und Normen thematisiert werden. }\end{array}$ \\
\hline
\end{tabular}


Basierend auf dem gemeinsam festgelegten Leitbildzielbereich wurden vier eintägige Veranstaltungen entwickelt, erprobt und optimiert. Für jede Jahreszeit wurde eine Veranstaltung erarbeitet. Exemplarisch soll an dieser Stelle eine Veranstaltung (Veranstaltung Kulturlandschaft) vorgestellt werden. Ziel der Veranstaltung ist es, Schüler(innen) durch informiertes Mitentscheiden zur Gestaltung eines Geländes zu befähigen. Schüler(innen) sollen ihre Umwelt partizipativ und vor allem zukunftsfähig mitgestalten können. Inhaltlich basiert die Veranstaltung auf einem fiktiven Szenario, welches den Schüler(inne)n zu Beginn der Veranstaltung erläutert wird (Box 5).

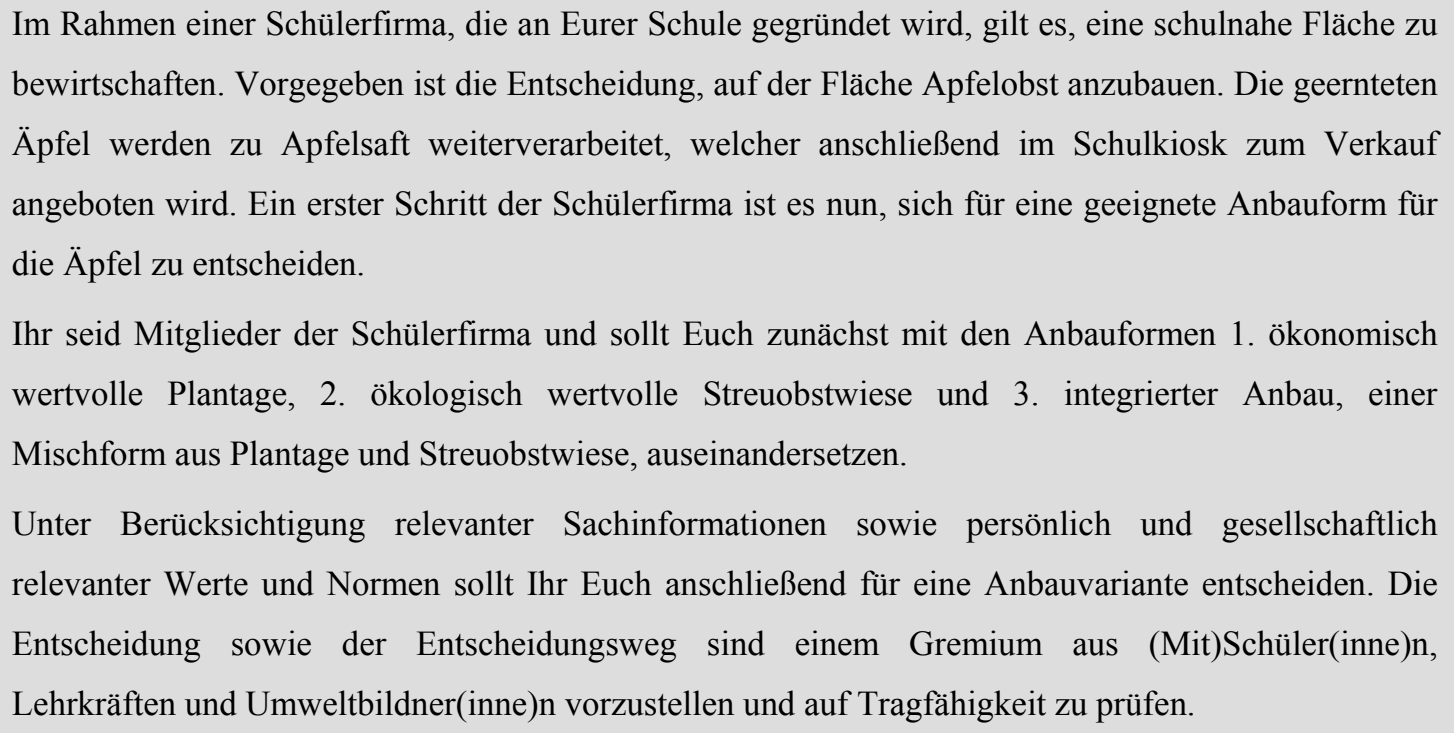

Box 5. Szenario und Arbeitsauftrag zur Veranstaltung Kulturlandschaft

Die Veranstaltung ist in vier Phasen untergliedert (Tabelle 13). Die erste Phase der Veranstaltung ermöglicht den Schüler(inne)n als motivierende Einführung zunächst das Erleben des Apfelanbaus auf einer artenreichen Streuobstwiese. Die Schüler(innen) beschreiben zunächst typische Merkmale dieses Ökosystems aus Obstbäumen und Wiesen und erörtern gemeinsam mit den Umweltbildner(inne)n die Bedeutung von Streuobstwiesen für die (lokale) Biodiversität (vgl. Bögeholz, 2006a). Anschließend lernen die Schüler(innen) die Verarbeitung von Apfelobst zu Apfelsaft kennen. Hierfür pflücken, zerkleinern und pressen die Schüler(innen) Äpfel (instrumentelle Naturerfahrung; Bögeholz, 2006b). Der gewonnene Apfelsaft wird verkostet (ästhetische Naturerfahrung; ebd.). Die Erfahrungen auf der Streuobstwiese werden am 
Ende der ersten Phase der Veranstaltung im Plenum unter Anleitung der Umweltbildner(innen) reflektiert. In der zweiten Phase erarbeiten und reflektieren die Schüler(innen) ökologische, ökonomische und soziale Sachinformationen sowie Werte und Normen in Bezug auf drei Anbauformen für Apfelobst: Plantage, Streuobstwiese, integrierter Anbau. Die Umweltbildner(innen) stellen hierfür Informationsmaterial in Form von Arbeitsblättern und Filmbeiträgen bereit. Die Schüler(innen) erarbeiten die Informationen arbeitsteilig und möglichst eigenverantwortlich in Kleingruppen (Gruppenpuzzle nach Aronson, 1984). In der dritten Phase bewerten die Schüler(innen) die verschiedenen Handlungsoptionen (Anbauformen), um eine begründete Entscheidung treffen $\mathrm{zu}$ können. Die Entscheidungsfindung erfolgt in Kleingruppenarbeit. Jede Gruppe präsentiert in der vierten Veranstaltungsphase ihre Entscheidung und ihren Entscheidungsweg einem Gremium aus Schüler(inne)n, Lehrkräften und dem umweltpädagogischen Personal. Die Entscheidungen und Entscheidungswege werden mit den Gremiumsmitgliedern kritisch diskutiert. In Tabelle 13 ist der Verlaufsplan der Veranstaltung abgedruckt. Zudem werden angesprochene Teilkompetenzen der Nationalen Bildungsstandards im Fach Biologie (KMK, 2005) aufgezeigt. Hervorgehobene Teilkompetenzen sind dem Kompetenzbereich Bewertung (ebd.) zuzuordnen. 
Tabelle 13. Verlaufsplan zur Veranstaltung Kulturlandschaft und angesprochene Teilkompetenzen (Bewertung fett gedruckt; nach KMK, 2005)

\begin{tabular}{|c|c|c|c|c|}
\hline $\begin{array}{l}\text { PHASE DER } \\
\text { VERANSTALTUNG }\end{array}$ & INHALTE - Schüler(innen) sollen... & $\begin{array}{l}\text { ARBEITS- } \\
\text { FORM }\end{array}$ & MATERIALIEN & $\begin{array}{l}\text { ANGESPROCHENE TEILKOMPETENZEN (KMK, 2005) } \\
\text { Schüler(innen)... }\end{array}$ \\
\hline $\begin{array}{l}\text { 1. Motivierung: } \\
\text { Streuobstwiese } \\
\text { kennenlernen und } \\
\text { Erfahrungen } \\
\text { reflektieren }\end{array}$ & $\begin{array}{l}\text { - eine fiktive Rahmengeschichte verstehen. } \\
\text { - Merkmale einer Streuobstwiese erarbeiten } \\
\text { und ihre Bedeutung für Biodiversität klären. } \\
\text { - Äpfel pflücken, pressen und verkosten. } \\
\text { - Naturerfahrungen reflektieren. }\end{array}$ & Plenum & $\begin{array}{l}\text { Saftpresse, } \\
\text { Messer, } \\
\text { Äpfel, } \\
\text { Trinkgläser }\end{array}$ & $\begin{array}{l}\text { F } 2.5 \text { beschreiben die strukturelle und funktionelle } \\
\text { Organisation im Ökosystem. } \\
\text { F } 2.6 \text { beschreiben und erklären die Angepasstheit ausgewählter } \\
\text { Organismen an die Umwelt. }\end{array}$ \\
\hline $\begin{array}{l}\text { 2. Sachinforma- } \\
\text { tionen zu Hand- } \\
\text { lungsoptionen } \\
\text { (Plantagenanbau, } \\
\text { Streuobstwiesenan- } \\
\text { bau und inte- } \\
\text { grierter Anbau) } \\
\text { erarbeiten, Werte } \\
\text { und Normen } \\
\text { erkennen }\end{array}$ & $\begin{array}{l}\text { - ökologische, ökonomische und soziale } \\
\text { Sachinformationen zu den Anbauformen für } \\
\text { Apfelobst (Plantage, Streuobstwiese, } \\
\text { integrierter Anbau) erarbeiten und } \\
\text { untereinander austauschen. } \\
\text { - entscheidungsrelevante Werte und Normen } \\
\text { identifizieren und untereinander diskutieren. } \\
\text { Anmerkung: } \\
\text { Sachinformationen,Werte und Normen sind - } \\
\text { dem Leistungsniveau der Schüler(innen) } \\
\text { entsprechend - im Sinne expliziter Bewertung } \\
\text { (Bögeholz, 2006a) zu erarbeiten. }\end{array}$ & Gruppenpuzzle & $\begin{array}{l}\text { Film zu } \\
\text { Anbauformen mit } \\
\text { Arbeitsauftrag, } \\
\text { Arbeitsblätter mit } \\
\text { Arbeitsaufträgen }\end{array}$ & $\begin{array}{l}\text { F } 2.5 \text { beschreiben die strukturelle und funktionelle } \\
\text { Organisation im Ökosystem. } \\
\text { F } 3.8 \text { kennen und erörtern Eingriffe des Menschen in die Natur } \\
\text { und Kriterien für solche Entscheidungen. } \\
\text { K } 4 \text { werten Informationen zu biologischen Fragestellungen aus } \\
\text { verschiedenen Quellen zielgerichtet aus und verarbeiten diese } \\
\text { auch mit Hilfe verschiedener Techniken und Methoden } \\
\text { adressaten- und situationsgerecht. } \\
\text { B } 1 \text { unterscheiden zwischen beschreibenden und } \\
\text { normativen Aussagen. } \\
\text { B } 5 \text { beschreiben und beurteilen die Auswirkungen } \\
\text { menschlicher Eingriffe in einem Ökosystem. } \\
\text { B } 7 \text { erörtern Handlungsoptionen einer umwelt- und } \\
\text { naturverträglichen Teilhabe im Sinne der Nachhaltigkeit. }\end{array}$ \\
\hline $\begin{array}{l}\text { 3. Handlungsop- } \\
\text { tionen bewerten } \\
\text { und entscheiden }\end{array}$ & $\begin{array}{l}\text { - Handlungsoptionen (Anbauformen) unter } \\
\text { Berücksichtigung der Informationen aus } \\
\text { Phase } 2 \text { miteinander vergleichen, um zu einer } \\
\text { begründeten Entscheidung zu gelangen. } \\
\text { - eine Präsentation des } \\
\text { Entscheidungsprozesses vorbereiten. }\end{array}$ & Kleingruppen & $\begin{array}{l}\text { Bewertungstabelle } \\
\text { mit Arbeitsauftrag, } \\
\text { Plakat für } \\
\text { Präsentation }\end{array}$ & $\begin{array}{l}\text { B } 7 \text { erörtern Handlungsoptionen einer umwelt- und } \\
\text { naturverträglichen Teilhabe im Sinne der Nachhaltigkeit. }\end{array}$ \\
\hline $\begin{array}{l}\text { 4. Entscheidung } \\
\text { reflektieren }\end{array}$ & $\begin{array}{l}\text { - ihre Entscheidung präsentieren und } \\
\text { reflektieren. }\end{array}$ & Plenum & & $\begin{array}{l}\text { B } 7 \text { erörtern Handlungsoptionen einer umwelt- und } \\
\text { naturverträglichen Teilhabe im Sinne der Nachhaltigkeit. }\end{array}$ \\
\hline
\end{tabular}




\section{Forschungsfragen}

Nach der einjährigen Phase zur Entwicklung und Umsetzung von Veranstaltungen unter Berücksichtigung des Leitbildes zur Biodiversitätsbildung soll die inhaltliche Kohärenz und die Qualität der Umsetzung des Leitbildbereichs Systematisches Bewerten reflektiert werden. Die Forschungsfragen lauten:

1. Wie schätzen die Umweltbildner(innen) die Gestaltung von Veranstaltungen unter Berücksichtigung des Leitbildziels Systematisches Bewerten retrospektiv ein?

2. Welche Hinweise gibt das pädagogische Personal zur Optimierung der Umsetzungen des Leitbildziels Systematisches Bewerten sowie des Leitbildziel selbst?

3. Welche Hinweise gibt die Studie zur Weiterentwicklung der Theorie zur Leitbildarbeit?

\section{Methoden}

Die durchgeführte Studie ist Bestandteil einer qualitätsentwickelnden, formativen Evaluation der Biodiversitätsbildung für die Heinz Sielmann Stiftung. Sie erfolgte in Anlehnung an den symbiotischen Implementationsansatz nach Gräsel und Parchmann (2004). Durch die gemeinsame Reflexion des neuen Leitbildziels Systematisches Bewerten und dessen Umsetzung sowie der gemeinsamen Weiterentwicklung können sowohl externe wissenschaftliche als auch interne Praxisanliegen berücksichtigt werden. Die praktischen Erfahrungen der Umweltbildner(innen) bilden dabei eine Grundlage für die Revisionsarbeit (vgl. z.B. Reinmann-Rothmeier \& Mandl, 1998). Durch die wissenschaftliche Begleitung - insbesondere auf Basis der theoretischen und normativen Vorgaben zu Bewertungskompetenz - wird eine Sicherung der inhaltlichen Qualität ermöglicht (vgl. z.B. Euler \& Sloane, 1998).

Die in dieser Untersuchung durchgeführte Reflexion des Leitbildziels und dessen Umsetzbarkeit basiert auf einer einjährigen Umsetzungsphase von Veranstaltungen nach dem Leitbild. Hierfür wurden vier prototypische Veranstaltungen von der Arbeitsgruppe gemeinsam entwickelt und jeweils für eine Veranstaltungszeit von sechs Zeitstunden für die Sekundarstufe I (7./8. Klasse) und II (11./12. Klasse) am Gymnasium aufbereitet. Die Veranstaltungen wurden mehrmals durch das pädagogische Personal auf dem 
Gelände der Heinz Sielmann Stiftung erprobt und in wissenschaftlicher Begleitung optimiert. Jede Veranstaltung wurde - je nach Teilnahmebereitschaft von Schulklassen drei- bis sechsmal umgesetzt.

Für die Reflexion und Weiterentwicklung der Leitbildarbeit wurde ein Fokusgruppengespräch, ein Gruppeninterview mit einem Gesprächsfokus, durchgeführt (nach Reinmann-Rothmeier \& Mandl, 1998; Morgan, 1998). Konkret ging es um eine Überprüfung und Optimierung der Passung des Leitbildes für den Lernort und der Qualität der Leitbildumsetzung. Die Fokusgruppe setzte sich aus sieben Teilnehmer(inne)n zusammen: vier Umweltbildner(inne)n (zwei weiblich, zwei männlich), der Referentin Umweltbildung der Heinz Sielmann Stiftung und zwei Biologiedidaktikerinnen. Auf Wunsch der Umweltbildner(innen) hin, wurde ein Sitzungsraum in der Biologiedidaktik der Universität als Ort für das Gespräch ausgewählt. Der Einsatz einer Fokusgruppe sollte dazu dienen, die Erfahrungen der Umweltbildner(innen) zur Arbeit mit den Leitbildzielen - darunter Systematisches Bewerten - zu ermitteln sowie Vorschläge für Optimierungsarbeiten zu diskutieren und festzulegen (Krueger \& Casey, 2000). Ziel der Diskussion war es, sowohl Erfahrungen als auch Optimierungsvorschläge gemeinsam zu reflektieren, zu ergänzen und so letztendlich zu Einschätzungen und Revisionsmaßnahmen für die Leitbildarbeit zu gelangen, die von allen Umweltbildner(inne)n getragen werden (Bloor, Frankland, Thomas \& Stewart, 2001; Bryman, 2004). Tabelle 14 zeigt am Beispiel des Ziels Systematisches Bewerten einen Ausschnitt aus dem verwendeten Interviewleitfaden. In ähnlicher Weise wie für dieses Ziel wurden Fragen für alle weiteren Ziele des Leitbildes gestellt. Die Didaktikerinnen steuerten den Verlauf der Diskussion mit Hilfe des Interviewleitfadens. Zudem waren sie für organisatorische Bedingungen, wie z.B. Zeitmanagement und Technik, verantwortlich. Zum anderen nahmen sie selbst an der Diskussion teil. Damit hatten sie als Teilnehmende und Forscherinnen in der Fokusgruppe eine Doppelrolle inne. 
Tabelle 14. Ausschnitt aus dem Interviewleitfaden zum Fokusgruppengespräch Beispiel Systematisches Bewerten

\begin{tabular}{|c|c|}
\hline ZIEL & INTERVIEWLEITFRAGEN \\
\hline 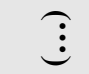 & - $\quad(\ldots)$ \\
\hline 离 & $\begin{array}{l}\text { - Inwieweit ließ sich das Leitbildziel Systematisches Bewerten mit seinen Teilzielen und } \\
\text { Qualitätsmerkmalen in Veranstaltungen zur Vermittlung von Bewertungskompetenz } \\
\text { umsetzen? } \\
\text { - Welche Bedingungen erleichterten oder erschwerten die Umsetzung des Leitbildziels? } \\
\text { - Inwieweit können Umsetzungen des Leitbildziels Systematisches Bewerten zukünftig } \\
\text { optimiert werden? } \\
\text { - Inwieweit soll das Leitbildziel Systematisches Bewerten mit seinen Teilzielen und } \\
\text { Qualitätsmerkmalen auch zukünftig in Veranstaltungen der Heinz Sielmann Stiftung } \\
\text { umgesetzt werden? }\end{array}$ \\
\hline$\widehat{\vdots}$ & - $(\ldots)$ \\
\hline
\end{tabular}

Die Diskussion wurde mit einem digitalen Diktiergerät aufgezeichnet und transkribiert (Mayring, 2002). Die Datenauswertung erfolgte in Anlehnung an die Qualitative Inhaltsanalyse nach Mayring (2008) und Gropengießer (2001). Hierfür wurden (1.) relevante Textstellen in ein Kategoriensystem eingeordnet, das aus deduktiv erstellten und induktiv ergänzten Kategorien bestand (Abbildung 9). Deduktive Kategorien wurden anhand des Göttinger Modells der Bewertungskompetenz (Bögeholz, 2007; Eggert \& Bögeholz, 2006) sowie des festgelegten Leitbildziels Systematisches Bewerten (vgl. Tabelle 12) abgeleitet. Für diesen Auswertungsschritt wurde das Analyseprogramm MAXqda 2007 verwendet. Um eindeutige Zuordnungen von Textstellen zu Kategorien vornehmen zu können, wurde jede Kategorie genau definiert und zusätzlich mit einem Ankerbeispiel versehen. Des Weiteren wurden bei bestehender Unsicherheit von Zuordnungen Ausschlussregeln formuliert (vgl. Mayring, 2008). Die kodierten Textstellen flossen in eine typisierende Strukturierung (Mayring, 2008) ein. Ziel dieses Auswertungsschrittes war es, die spezifischen Einschätzungen der Gruppe herauszuarbeiten. Hierbei waren ausschließlich jene Aussagen von Interesse, auf die sich - im Sinne des Fokusgruppengesprächs - die Umweltbildner(innen) als Gruppe einigen konnten (z.B. Morgan, 1997). Um eine objektive Vorgehensweise gewährleisten 
zu können (nach Flick, 2004), wurde die Auswertung von drei Personen zunächst unabhängig durchgeführt und anschließend gemeinsam diskutiert (siehe auch Czech, 2008; Mackensen, 2007).

\begin{tabular}{|c|c|}
\hline$\square$ 틀 Systematisches Bewerten & 0 \\
\hline E Einstellung gegenüber Kompetenzbereich Bewertung & 11 \\
\hline E Bedingungen für aufierschulische Bewertungen & 30 \\
\hline EVeranstaltungszeit & 13 \\
\hline 빌. Umgang mit Heterogenität & 8 \\
\hline EAlltagsbezug & 9 \\
\hline 틀 Bewerten, Entscheiden und Reflektieren & 0 \\
\hline ESachinformationen Generieren und Reflektieren & 12 \\
\hline @ Vorbereitung und Verwendung von Informationstexten & 12 \\
\hline EVerstehen von Werten und Normen & 0 \\
\hline @ Verstehen von Nachhaltiger Entwicklung & 9 \\
\hline Eignung des Kontextes für Bewertungsaufgaben & 9 \\
\hline E Verzahnung außjerschulischer Vermittlung mit Schulunterricht & 13 \\
\hline 틀 Leitbild-Ziele in der Retrospektive & 0 \\
\hline 늘 Leitbild-Qualitätsmerkmale in der Retrospektive & 0 \\
\hline
\end{tabular}

Abbildung 9. Ausschnitt aus dem Kategoriensystem: Kategorien zum Leitbildziel Systematisches Bewerten

\section{Ergebnisse}

Im Folgenden werden die Ergebnisse der durchgeführten Analysen zum Leitbildziel Systematisches Bewerten aufgezeigt. Auszüge aus dem Fokusgruppentranskript geben dabei beispielhaft Einblick in die Originalaussagen der Umweltbildner(innen) ${ }^{14}$. Zur Überprüfbarkeit der Redeabsätze werden die dargestellten Aussagen mit „Z“ für „Zeile im Transkript“ angegeben. Um eine anonyme Darstellung der Aussagen zu gewährleisten, werden die Namen der Fokusgruppenteilnehmer(innen) jeweils durch UB1, UB2,.., UB5 ersetzt. Um den Zusammenhang der Ergebnisdarstellung mit den Kategorien in Abbildung $9 \mathrm{zu}$ verdeutlichen, sind Kategoriebezüge durch Unterstreichen hervorgehoben. 
Die Analysen zeigen, dass die Umweltbildner(innen) die Notwendigkeit betonen, Bewertungskompetenz zu vermitteln. Bewertungen in Veranstaltungen einzubinden, schätzen sie jedoch als schwierig ein.

UB5: „Aber insgesamt, glaube ich, haben wir uns alle bis zuletzt schwer getan diese ganze Bewertung zu machen.“ (Z 714-715)

[...]

UB5: „Weil es [...] braucht unheimlich viel Input, damit eine Bewertung laufen kann und da muss man halt gucken, wie man das vorher hinkriegt, dass man auch die notwendigen Informationen vermittelt und die Bewertung selber ist wirklich schwierig mit Schülern durchzuführen. Das sie den Sinn der Sache verstehen [...]“ (Z 719-722)

[...]

UB5: „Das umzusetzen. Also fand ich bis zuletzt. Egal wie wir dies probiert haben.“ (Z 726)

$[\ldots]$

UB1: „[...] Bewerten finde ich aber trotzdem, hast du recht, müssen sie können, denn dies ist eine wichtige Kompetenz. Zum Schluss soll für die Kinder was dabei rauskommen. “(Z 865-867)

Sie nennen einige Bedingungen, welche die Durchführung von Bewertungen ihrer Meinung nach erschweren. Beispielsweise geben sie an, dass ihnen in ihren Veranstaltungen zu wenig Zeit für die Durchführung von Bewertungen mit Schüler(inne)n zur Verfügung stand.

UB1: „So und dann insofern ist es richtig, muss das Bewerten schon mit rein, aber ich finde in dieser Sechsstundenveranstaltung ist das super schwierig. “ (Z 881-882)

Besonders zeitintensiv war das Erarbeiten von Bewertungskriterien mit den Schüler(inne)n im Sinne einer expliziten Bewertung (Ahlf-Christiani, Dierks, von Gadow, Hübner, Malm, Schulz \& Warning-Schröder, 2003; Bögeholz, 2006a), bei der Schüler(innen) einen Bewertungsprozess selbst planen. Dennoch befürworten sie diese Vorgehensweise, weil die Schüler(innen) dadurch lernen, sich kritisch mit Bewertungskriterien auseinanderzusetzen.

UB3: „Und was ich eigentlich gar nicht so schlecht fand, war, wir haben ja versucht, diese Kriterien selber zu erarbeiten. Damit [können] sie für sich selber mal reflektieren [...], warum steht das da jetzt, warum habe ich mich jetzt dafür entschieden, dass das [...] ein Kriterium sein soll. “ (Z 1150-1153)

$[\ldots]$

UB3: „[...] das fand ich ganz zielführend aber auch sehr zeitraubend.“ (Z 1163-1164)

Weiterhin werden die verwendeten Informationstexte zur Generierung von Sachinformationen kritisiert. Die Umweltbildner(innen) stellen fest, dass die entwickelten Materialien nicht für jede Schüler(innen)gruppe gleichermaßen geeignet sind. Sie 
geben an, dass es ihnen schwerfiel, die Materialien für die teilnehmenden Schulklassen dem jeweiligen Leistungsniveau entsprechend angemessen $\mathrm{zu}$ verändern und in der Umsetzung zielführend zu verwenden.

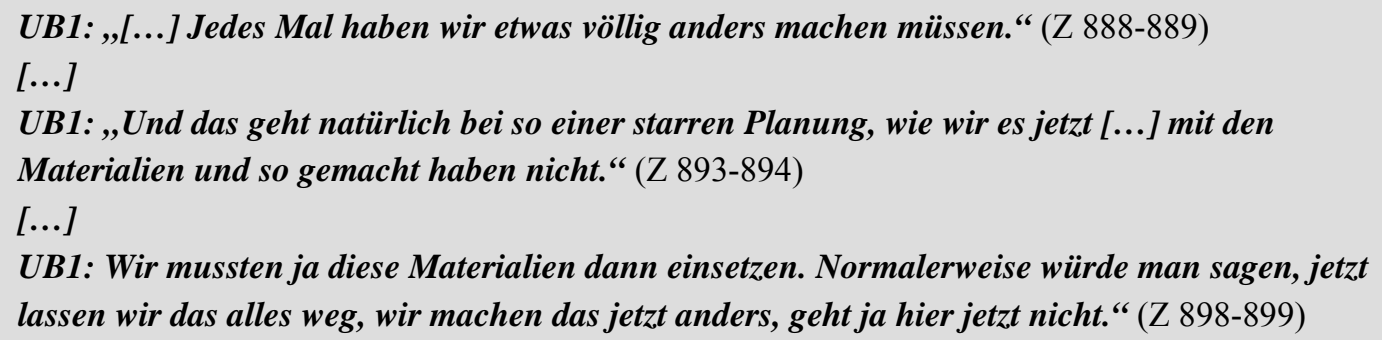

In der Heterogenität von Schüler(inne)n sieht das pädagogische Personal eine weitere Bedingung, welche die Durchführung von Bewertungen erschwert. Vor allem der unterschiedliche Stand des Vorwissens der Schüler(innen) erschwert den Umweltbildner(inne)n die Umsetzung von Bewertungsaufgaben.

UB1: „[...] Dann haben die Klassen unterschiedliche Ausgangs-“ (Z 850)

UB3: „Voraussetzungen“ (Z 852)

UB1: „Voraussetzungen, Grundvoraussetzungen von ihrer Vorbildung her, dann von den Pädagogen her. Dann sind sie unterschiedlich alt und dann haben wir noch einen gewissen Anspruch was möglicherweise bei dieser Veranstaltung raus kommen muss [...]“ (Z 854-856)

[....]

UB1: „Und ich denke, dass ist fast nicht unter einen Hut zu kriegen.“ (Z 861)

Neben erschwerenden Bedingungen für die Durchführung von Bewertungen diskutieren die Umweltbildner(innen) auch den Alltagsbezug von Bewertungsaufgaben. Es ist ihnen wichtig, dass sich Bewertungen an der Lebenswelt der Schüler(innen) orientieren. Schüler(innen) sollten einen Bezug zu den dargebotenen Entscheidungsproblemen haben.

UB1: „[...] das Interesse ist ja da, wenn man an Bekanntes anknüpft. Deswegen finde ich diesen Ansatz, an Bekanntes anzuknüpfen, gut, auch bei der Bewerterei [...]“ (Z 1201-1203)

Im Kontext Nachhaltiger Entwicklung scheinen vor allem Situationen geeignet zu sein, die das Konsumverhalten von Schüler(inne)n betreffen.

Des Weiteren wird in der Fokusgruppe die Verzahnung von außerschulischem und schulischem Lernen in Bezug auf Bewertungen diskutiert. Die Umweltbildner(innen) betonen, dass Bewertungen hauptsächlich im Schulunterricht stattfinden sollten. 
Außerschulische Lernangebote können hierbei unterstützend genutzt werden, sollten die Umsetzung von Bewertungen jedoch nicht vollständig übernehmen.

UB2: „Die [Lehrer] können sich ein bisschen Hilfe holen, aber jetzt nicht praktisch und so große komplexe [Kompetenzbereiche] komplett extern bearbeiten zu lassen. “ ( $Z$ 2496-2497)

In der Diskussion um die Einschätzung von Veranstaltungen zur Vermittlung von Bewertungskompetenz äußerten die Umweltbildner(innen) - auf Grundlage der Impulse des Interviewleitfadens (vgl. Tabelle 14, S. 80) - keine Kritik an den aufgestellten Teilzielen und Qualitätsmerkmalen zum Leitbildziel Systematisches Bewerten selbst.

\section{Diskussion und Ausblick}

Die Umweltbildner(innen) beschreiben Bewertungskompetenz als ein wichtiges Bildungsziel, das von Schüler(inne)n erlernt werden muss, um tragfähige Entscheidungen treffen zu können ( $Z$ 865-867). Vor allem explizite Bewertungen ( $Z$ 1150-1153; siehe hierzu auch Bögeholz, 2006a) sowie Bewertungen mit konkretem Bezug zur Lebenswelt der Schüler(innen) (Z 1201-1203; siehe hierzu auch Eggert \& Hößle, 2006; Meyer, 2006) schätzen sie als sinnvoll ein. Durch diese Einschätzung wird die Einstellung der Gruppe deutlich. Als Einstellung wird die allgemeine positive oder negative Bewertung eines Verhaltens bezeichnet (Ajzen, 2005). Die Ergebnisse der Untersuchung zeigen, dass die Umweltbildner(innen) als Gruppe eine positive Einstellung gegenüber Bewertungskompetenz haben. Eine positive Einstellung gegenüber Bewertungen ist für eine Vermittlung von Bewertungskompetenz von zentraler Bedeutung (vgl. Cotton, 2006). Sie kann dazu beitragen, die Absicht des pädagogischen Personals zu fördern, Systematisches Bewerten in Veranstaltungen umzusetzen (Ajzen, 2005) und stellt somit eine bedeutsame Vorraussetzung für den außerschulischen Beitrag zur Förderung von Bewertungskompetenz dar.

Eine Umsetzung von Systematischem Bewerten kann jedoch durch erschwerende Umsetzungsbedingungen behindert werden (Ajzen, 2005). Die Untersuchung zeigt, dass die Umweltbildner(innen) Schwierigkeiten bei der Erfüllung didaktischmethodischer Anforderungen (z.B. Helmke, 2009) in Veranstaltungen wahrnehmen. Sie geben Schwierigkeiten in der Auswahl und Verwendung von Arbeitsmaterialen an. Vor allem die Aufbereitung von Sachinformationstexten, die dem Leistungsniveau der Schüler(innen) entsprechen, schätzen sie als schwierig ein (Z 888-889, 893-894, 898- 
899). Vor der gemeinsamen Arbeit mit der Wissenschaft führten die Umweltbildner(innen) - aufgrund einer überwiegend praktisch angelegten Bildungsarbeit selten Veranstaltungen durch, in denen Informationstexte zur Bearbeitung von Aufgaben verwendet wurden. Sachinformationstexte für Bewertungen zum Schutz und zur Nachhaltigen Nutzung von Biodiversität zu erstellen bedeutet, eine - dem Leistungsniveau der Schüler(innen) entsprechend - komplexe Sachlage abzubilden (Bögeholz \& Barkmann, 2003). Eine besondere Schwierigkeit stellt dabei der Umgang mit dem unterschiedlichen Stand des Vorwissens (vgl. Hasselhorn \& Gold, 2006) bei Schüler(inne)n dar (Z 850, 852, 854-856, 861). Die Umweltbildner(innen) haben nahezu keine Erfahrung in der Bewältigung dieser Herausforderung. Um zukünftige Umsetzungen von Veranstaltungen zur Vermittlung von Bewertungskompetenz zu optimieren, können zum einen Fortbildungsmaßnahmen zu didaktisch-methodischen Anforderungen (vgl. Helmke, 2009) sowie zur Bedeutung der Berücksichtigung von Vorwissen (Hasselhorn \& Gold, 2006) hilfreich sein. Zum anderen können weitere Umsetzungen von Veranstaltungen zum Systematischen Bewerten dazu beitragen, weitere Erfahrungen mit der Aufbereitung von Sachinformationstexten für Schüler(innen) zu gewinnen. Diese können für Optimierungsarbeiten genutzt werden und Sicherheit in der flexiblen Reaktion auf unterschiedliches (Vor)Wissen geben.

Neben Schwierigkeiten in Bezug auf eine Erfüllung didaktisch-methodischer Anforderungen nimmt das pädagogische Personal auch erschwerende organisatorische Rahmenbedingungen (vgl. Schratz, 2003) wahr. Als zentraler Kritikpunkt wird die Länge der Veranstaltungszeit genannt. Für die erprobten Veranstaltungen wurde jeweils ein Zeitrahmen von sechs Zeitstunden gewählt. Dieser Zeitrahmen wurde aus pragmatischen Gründen festgelegt. Zum einen war es nicht möglich, mehr als einen Tag für die Teilnahme einer Schulklasse einzuplanen. Zum anderen waren die Schüler(innen) an feststehende Busfahrzeiten gebunden. Um zukünftig Umsetzungen optimieren zu können, ist eine enge Verzahnung der außerschulischen Bildung mit Schulunterricht sinnvoll. Hierzu geben die Umweltbildner(innen) an, dass sie basierend auf ihren Erfahrungen - eine Vermittlung von Bewertungskompetenz vorrangig im Schulunterricht verorten würden. Außerschulische Bildung kann jedoch dazu beitragen, diese Vermittlung zu unterstützen, sollte sie aber nicht ersetzen ( $Z$ 2496-2497). Eine konkrete Planung der Zusammenarbeit von Schule und außerschulischem Lernort wurde in dem Fokusgruppengespräch nicht diskutiert. Aus 
Perspektive der Forschung wäre jedoch eine Zusammenarbeit in Anlehnung an Bögeholz, Bittner und Knolle (2006) denkbar. Das Konzept bildet idealtypische Unterrichtsbausteine zur Vermittlung von Bewertungskompetenz ab. Zudem werden gezielt Möglichkeiten aufgezeigt, die Stärken außerschulischen Lernens zu integrieren. Hierbei handelt es sich vor allem um praktisch orientierte Bereiche. Für die stärker kognitiv orientierten Bausteine bietet sich eine Umsetzung in der Schule an (Bögeholz, Bittner \& Knolle, 2006). Abbildung 10 zeigt beispielhaft eine mögliche Anwendung des Ansatzes (ebd.) auf die in diesem Artikel vorgestellte Veranstaltung (Kulturlandschaft). Bei der Umsetzung der Veranstaltungsbausteine 1. Motivierung: Streuobstwiese kennenlernen und Erfahrungen reflektieren, 2.1 Werte und Normen erkennen sowie 2.2 Sachinformationen zu Handlungsoptionen (Plantagenanbau, Streuobstwiesenanbau und integrierter Anbau) erarbeiten ist eine Nutzung außerschulischer Lernangebote denkbar (grau schraffierte Bausteine). Inwieweit eine außerschulische Vermittlung der Bausteine erfolgen soll, muss in einem Aushandlungsprozess zwischen Schule und außerschulischem Lernort geklärt werden. Hierbei gilt es, die Möglichkeiten des Lernortes, die Ziele der teilnehmenden Gruppen aber auch bestehende Erfahrungen in der gemeinsamen Zusammenarbeit zu berücksichtigen. In Abbildung 10 werden für eine vorrangige Umsetzung im Schulunterricht die Veranstaltungsbausteine 3. Handlungsoptionen bewerten und entscheiden und 4. Entscheidung reflektieren vorgeschlagen (grau hinterlegte Bausteine). Zusätzlich ist eine schulische Vermittlung kognitiv orientierter Elemente des Bausteins 2.1 Werte und Normen erkennen denkbar (siehe Abbildung 10). Der Ansatz von Bögeholz, Bittner und Knolle (2006) wird in diesem Vorschlag erweitert um explizite Absprachen der Umweltbildner(innen) mit den jeweils beteiligten Lehrkräften: Vorgeschlagen wird, vor der Umsetzung von Veranstaltungsbausteinen gemeinsam die konkrete Zusammenarbeit zu planen. Nach der Umsetzung sollten erneut die Umweltbildner(innen) als auch die Lehrkräfte gemeinsam die Zusammenarbeit reflektieren und für zukünftige gemeinsame Planungen und Durchführungen Schlussfolgerungen ziehen. Gemeinsame Erfahrungen bedingen damit die Intensität und Qualität der weiteren Zusammenarbeit zwischen Schule und außerschulischem Lernort. 
Umweltbildner(innen) und Lehrkräfte planen gemeinsam die Umsetzung

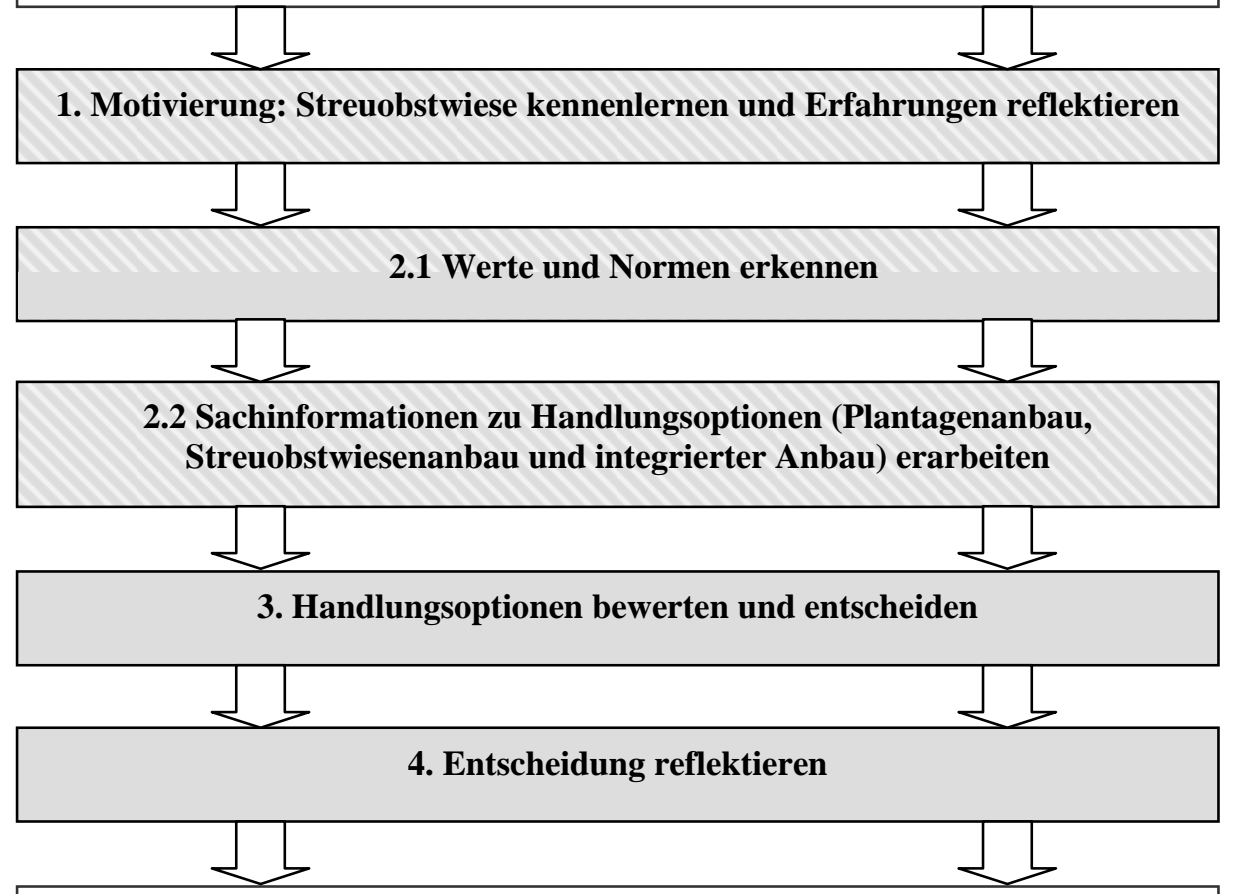

Umweltbildner(innen) und Lehrkräfte geben sich gegenseitig Feedback

Mögliche Einbindung außerschulischer Lernangebote

Vorrangige Umsetzung im Schulunterricht

Abbildung 10. Mögliche Umsetzung der Veranstaltung Kulturlandschaft in Zusammenarbeit von Schule und außerschulischem Lernort (in Anlehnung an Bögeholz, Bittner \& Knolle, 2006)

In Bezug auf die festgelegten Teilziele und Qualitätsmerkmale des Leitbildziels Systematisches Bewerten selbst geben die Umweltbildner(innen) keine Verbesserungsvorschläge an. Es wird an dieser Stelle angenommen, dass die Umweltbildner(innen) das Ziel mit seinen Teilzielen und Qualitätsmerkmalen auch nach der praktischen Umsetzung als grundsätzlich umsetzbar einschätzen. Somit wird das definierte Leitbildziel vorerst unverändert weitergeführt. Entsprechend des Vorschlags von Bögeholz, Bittner und Knolle (2006) wäre jedoch aus Forschungsperspektive nachträglich eine Modifizierung denkbar, bei der: 
- auf Stärken des außerschulischen Lernorts fokussiert wird und

- die Potentiale des Lernorts für „Ökologie im Freien“ systematisch eingebunden werden.

Die vorliegende Studie stellt somit im Rahmen einer reflexiven Leitbildarbeit einen ersten (wichtigen) Schritt in der Reflexion und Weiterentwicklung des Leitbildzielbereichs Systematisches Bewerten - insbesondere der Qualität dessen Umsetzung - dar. In einem weiteren Schritt ist der Modifizierungsvorschlag zur Veranstaltung Kulturlandschaft in Abbildung 10 mit dem pädagogischen Personal zu diskutieren, zu konkretisieren und abzustimmen, um gezielte Weiterentwicklungen zu initiieren. Zudem ist zu prüfen, inwieweit eine Passung der Teilziele und Qualitätsmerkmale des Leitbildziels für den Lernort gegeben ist bzw. inwieweit es diese - u.a. unter Einbezug der Vorschläge aus Forschungsperspektive (siehe oben) - zu optimieren gilt.

Ein gestaffeltes Vorgehen bei der Reflexion und Weiterentwicklung des Leitbildes und dessen Umsetzung kann auch zukünftig die reflexive Leitbildarbeit des Lernorts erleichtern.

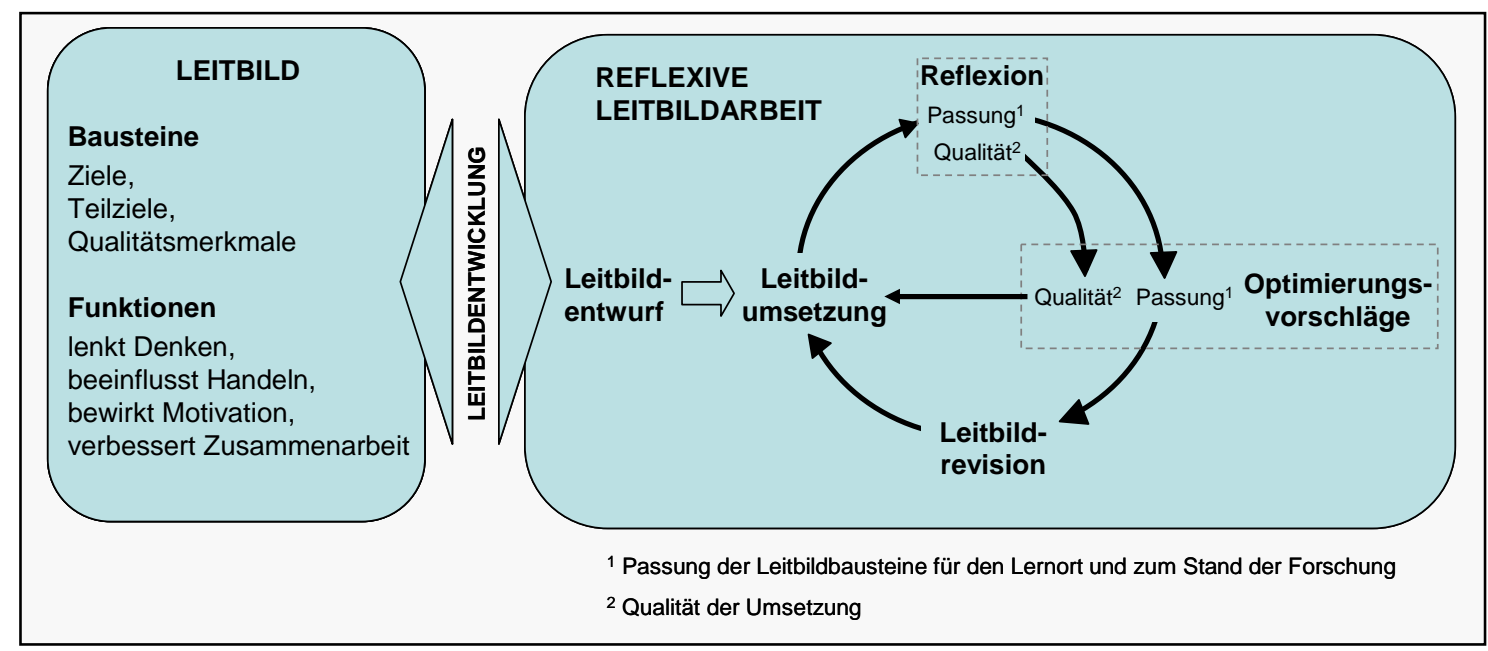

Abbildung 11. Kontinuierliche Leitbildarbeit, erfahrungsbasiert modifiziert

Dabei werden in einem ersten Schritt die Qualität der Leitbildumsetzung sowie die Passung des Leitbildes für den Lernort kritisch überprüft. Zudem sollte zukünftig auch die Passung des Leitbildes zum Stand der Forschung hinterfragt werden (Reflexion in Abbildung 11). In einem weiteren Schritt werden Optimierungsvorschläge generiert 
(Optimierungsvorschläge), die zum einen dazu genutzt werden, die Qualität von Leitbildumsetzungen weiterzuentwickeln und die zum anderen dazu dienen, die Passung und damit das Leitbild selbst weiterzuentwicklen (Leitbildrevision). Die konkreten Vereinbarungen zur Optimierung von Qualität und Passung fließen in erneuten Leitbildumsetzungen zusammen (siehe zyklischer Prozess in Abbildung 11).

\section{Kritische Betrachtung der methodischen Vorgehensweise}

Die Untersuchung erfolgte - gemäß des symbiotischen Implementationsansatzes (Gräsel \& Parchmann, 2004) - in Zusammenarbeit von Wissenschaft und Praxis. Der Einbezug der Umweltbildner(innen) in die Leitbildarbeit hat dazu beigetragen, dass sich die Praktiker(innen) mit dem Vorhaben identifizieren konnten und motiviert wurden, auch zukünftig für die Qualitätsentwicklung ihrer Bildungsangebote Verantwortung zu übernehmen (Giesel, 2007; Gräsel \& Parchmann, 2004; Kempfert \& Rolff, 2004). Die durchgeführte Reflexion und Weiterentwicklung des gemeinsam festgelegten Leitbildes und dessen Umsetzung hat dazu beitragen, den Umweltbildner(inne)n zu verdeutlichen, dass die (erfahrungsbasierte) reflexive Leitbildarbeit ein zentraler Bestandteil einer kontinuierlichen Leitbildarbeit ist (Giesel, 2007). Die Durchführung eines Fokusgruppengesprächs bot dabei den Umweltbildner(inne)n die Möglichkeit, ihre Erfahrungen zur Umsetzbarkeit des Leitbildziels Systematisches Bewerten anzusprechen, gemeinsam zu diskutieren und für Optimierungsvorschläge nutzen zu können (Morgan, 1997). Dennoch barg die Anwendung der Methode Fokusgruppe (ebd.) auch Schwächen. So konnten keine konkreten Aussagen zur Passung von Teilzielen und Qualitätsmerkmalen des Zielbereichs Systematisches Bewerten für den Lernort gewonnen werden. Eine gezielte Gesprächssteuerung durch die moderierenden Biologiedidaktikerinnen wäre an dieser Stelle wünschenswert gewesen. Erklärt werden kann die unzureichende Gesprächslenkung zum einen durch den eingesetzten Interviewleitfaden (siehe Tabelle 14). Der Leitfaden fokussiert nicht deutlich genug auf eine kritische Einschätzung der Passung von Teilzielen und Qualitätsmerkmalen für den Lernort selbst. Zudem wurden Fragen zur Passung des Leitbildes zum Stand der Forschung bislang noch nicht berücksichtigt. Für zukünftige Untersuchungen sollte der Leitfaden entsprechend optimiert und erweitert werden. 
Zum anderen ist die Doppelrolle der Moderatorinnen in der Fokusgruppe zu betonen. Die Didaktikerinnen steuerten einerseits das Gespräch inhaltlich (Orientierung am Interviewleitfaden) als auch organisatorisch (Zeitmanagement, Technik). Andererseits nahmen sie selbst an der inhaltlich umfangreichen Diskussion teil. Obwohl die Diskussion von zwei Moderatorinnen gesteuert wurde (vgl. hierzu Morgan, 1997), gelang die Wahrnehmung beider Rollen nicht immer optimal. Entsprechend des Vorschlags in Abbildung 11 sollte die reflexive Leitbildarbeit zukünftig in gestaffelten Veranstaltungen (zur Reflexion, zu Optimierungsvorschlägen und zur Revision) erfolgen. Durch die damit begrenzte Zielsetzung jeder Einzelveranstaltung sowie den damit verbundenen inhaltlich begrenzten Diskussionsumfang kann auch eine Moderation reflexiver Leitbildarbeit optimiert werden.

Des Weiteren ist zu bedenken, dass das Phänomen Gruppe die Aussagen der Fokusgruppenteilnehmer(innen) beeinflussen kann. Es muss davon ausgegangen werden, dass nicht alle vorhandenen Einschätzungen geäußert wurden und damit analysiert werden konnten (z.B. wenn sie nicht mit der Gruppenmeinung übereinstimmen). Zudem ist anzunehmen, dass vorrangig sozial erwünschte, das heißt gruppenverträgliche Perspektiven geäußert wurden (Morgan, 1997). Persönliche (bewusste und unbewusste) Einschätzungen einzelner Umweltbildner(innen) darüber, wie Bildungsveranstaltungen in der Heinz Sielmann Stiftung gestaltet werden sollten, können - wenn sie nicht von der Leitbildarbeit erfasst wurden - mit der (gruppengesteuerten) Leitbildarbeit konkurrieren und diese damit erschweren (Giesel, 2007). Um sogenannte subjective beliefs (persönliche Überzeugungen, Ajzen, 2005) der Umweltbildner(innen) identifizieren $\mathrm{zu}$ können, wurden im Gesamtprojekt der formativen Evaluation Einzelinterviews (Mayring, 2002) mit den Umweltbildner(inne)n durchgeführt.

Die vorliegende Studie gibt modellhaft einen Einblick in erste Schritte einer reflexiven Leitbildarbeit (Giesel, 2007) zur Unterstützung außerschulischer Lernorte für kompetenzorientierten Unterricht am Beispiel des Kompetenzbereichs Bewertung (KMK, 2005; Niedersächsisches Kultusministerium, 2008, 2007). Obschon das pädagogische Personal dieser Bildungseinrichtung durch enge Zusammenarbeit zwischen Wissenschaft und Praxis bereits hochgradig fortgebildet war, gab die Studie Hinweise, welche Schwächen in der Bildungsarbeit der Stiftung als Regionales Umweltbildungszentrum in Zukunft aufgegriffen werden sollten. Darüber hinaus zeigte 
die Studie, dass eine reflexive Leitbildarbeit eine nicht $\mathrm{zu}$ unterschätzende Herausforderung darstellt. Insbesondere den Schritt von der Reflexion zur Weiterentwicklung und Umsetzung des verbesserten Leitbildes gilt es (nach einem zyklischen Modell reflexiver Leitbildarbeit) zu gestalten. 


\section{Zusammenfassung und Diskussion}

Die vorgestellten Teilstudien wurden durchgeführt, um das Angebot für Biodiversitätsbildung der Heinz Sielmann Stiftung formativ zu evaluieren. Sie dienten dazu, Informationen über die Qualität des Bildungsangebots systematisch zu sammeln, $\mathrm{zu}$ analysieren und $\mathrm{zu}$ bewerten, um Entscheidungen für Optimierungsmaßnahmen treffen zu können (Kempfert \& Rolff, 2005; Burkhard \& Eikenbusch, 2000). Das übergeordnete Ziel der Evaluationsstudie war es damit, die Gestaltung des Bildungsangebots so zu optimieren, dass eine optimale Grundlage für einen möglichst hohen Lernerfolg bei Schüler(inne)n geschaffen werden kann (Wottawa \& Thierau, 2003). Die Durchführung der vorgestellten Teilstudien trug dazu bei, einen möglichst umfassenden Einblick in die Qualität des Bildungsangebots zu gewinnen (vgl. Flick, 2008; von Kardorff, 2008). Dabei konnten in den Teilstudien folgende Erkenntnisse gewonnen werden.

Basierend auf einem gemeinsam von Wissenschaft und Praxis erarbeiteten wissenschaftlichen Fundament wurde in Teilstudie 1 ein Leitbild mit Zielen, Teilzielen und Qualitätsmerkmalen (nach Giesel, 2007; Kempfert \& Rolff, 2005; Schratz, 2003) als Orientierungsrahmen für die Entwicklung, Umsetzung und gegebenenfalls Optimierung von Bildungsveranstaltungen zu Biodiversität von der Arbeitsgruppe festgelegt. Das Leitbild zeigt auf, worin die Arbeitsgruppe Qualität einer Biodiversitätsbildung der Heinz Sielmann Stiftung versteht. Die Ziele (Teilziele und Qualitätsmerkmale) orientieren sich sowohl an den Vorgaben für eine Bildung für Nachhaltige Entwicklung (BMBF, 2002; Deutsche UNESCO-Kommission e.V. / Nationalkomitee UN-Dekade „Bildung für Nachhaltige Entwicklung“, 2008; de Haan, 2008; BMZ/KMK, 2007) als auch an curricularen Anforderungen (Fach Biologie; KMK, 2005; Niedersächsisches Kultusministerium, 2007, 2008) sowie den umweltpädagogischen Leitlinien der Heinz Sielmann Stiftung (Bögeholz, Stelte \& Säger, 2005). Das Leitbild berücksichtigt somit 1) den aktuellen Stand der Forschung zu Bildung für Nachhaltige Entwicklung, 2) Bedürfnisse des Schulunterrichts sowie 3) das Bildungsanliegen des beteiligten außerschulischen Lernortes. Da die Heinz Sielmann Stiftung als Regionales Umweltbildungszentrum des Landes Niedersachsen dazu aufgerufen ist, sowohl Bildung für eine Nachhaltige Entwicklung zu fördern als auch Schulunterricht zu unterstützen (Niedersächsisches Kultusministerium, 2006), sind 
durch eine Orientierung der Umweltbildner(innen) am neuen Leitbild theoretisch optimale Voraussetzungen dafür geschaffen, die Anforderungen des Landes an den Lernort zu erfüllen.

$>$ Eine wissenschaftliche Begleitung der Umsetzung erster Veranstaltungen nach dem Leitbild für die Sekundarstufe I konnte zeigen, dass die Qualität von Veranstaltungen im Hinblick auf eine Umsetzung des Leitbildes hoch ist. Vor allem Zielbereiche, die den Umweltbildner(inne)n als originäre Naturwissenschaftler(innen) vertraut sind (Ziel 4 Wissen zu Landschaftsentwicklung und Ziel 6 Naturwissenschaftliche Arbeitsweisen), wurden erfolgreich umgesetzt.

$>$ Jedoch wurden auch Defizite festgestellt. Insbesondere Umsetzungen innovativer Ziele, wie z. B. Ziel 5 Systematisches Bewerten, wiesen Mängel auf. Es ist anzunehmen, dass die Umweltbildner(innen) mit zunehmenden Erfahrungen in der Umsetzung des Leitbildes mehr Sicherheit im Umgang mit innovativen Zielen gewinnen können. Eine Konzentration auf zunächst nur wenige Qualitätsmerkmale in Veranstaltungen könnte diese Entwicklung zusätzlich unterstützen.

Neben dem innovativen Charakter einiger Leitbildziele wurden jedoch auch Hinweise identifiziert, die vermuten lassen, dass eine mangelnde didaktischmethodische Professionalisierung der Umweltbildner(innen) $\mathrm{zu}$ Defiziten in der Erfüllung des Leitbildes führten. Entsprechend könnten Weiterbildungen der Umweltbildner(innen) bzw. ein professionelles Coaching zu didaktisch-methodischen Anforderungen an Bildungsmaßnahmen (vgl. z.B. Helmke, 2009) zu einer angemessenen Erfüllung der Leitbildziele beitragen.

Nach Helmke (2009) muss eine Qualitätsentwicklung von Bildungsmaßnahmen auch die subjektiven Einschätzungen der Umweltbildner(innen) berücksichtigen. Um die Erkenntnisse der Teiluntersuchung 1 um Einblicke in die impliziten Theorien der Umweltbildner(innen) zu ergänzen, wurde eine zweite Teilstudie durchgeführt. Angelehnt an die Theory of Planned Behavior (Ajzen, 2005, 2008) wurde die Absicht, Veranstaltungen nach dem Leitbild zu gestalten, als zentraler Prädiktor für eine (angemessene) Leitbildorientierung (vgl. Ajzen, 2005, 2008) untersucht. Folgende Erkenntnisse wurden gewonnen. 
Die Umweltbildner(innen) haben überwiegend eine positive Einstellung gegenüber dem neuen Leitbild. Diese fördert die Absicht, Veranstaltungen nach dem Leitbild zu gestalten (Ajzen, 2005; Frey, Stahlberger \& Gollwitzer, 2001).

Die Umweltbildner(innen) nehmen sozialen Druck (insbesondere durch Personen der Heinz Sielmann Stiftung und die wissenschaftliche Begleitung) wahr, sich bei der Entwicklung und Umsetzung von Veranstaltungen am neuen Leitbild zu orientieren. Die subjektive Norm fördert die Absicht der Umweltbildner(innen) ebenfalls (ebd.).

Im Hinblick auf eine wahrgenommene Verhaltenskontrolle nehmen die Umweltbildner(innen) Bedingungen wahr, die eine Orientierung am Leitbild erschweren können. Hierzu zählen u. a. zu wenig Auseinandersetzung mit dem Leitbildziel 5 Systematisches Bewerten, mangelnde Kenntnis didaktisch-methodischer Planungsaspekte von Bildungsmaßnahmen (z.B. Helmke, 2009) sowie zu viele angestrebte Qualitätsmerkmale in einer Veranstaltung. Zu einem großen Teil werden Lösungsmöglichkeiten für die genannten Bedingungen angegeben, sodass angenommen werden kann, dass die Umweltbildner(innen) die Bedingungen überwiegend als kontrollierbar einschätzen. Der Beitrag, den die genannten Bedingungen auf die Verhaltensabsicht haben, ist daher eher gering (ebd.; Ajzen, 2008). Die genannten Bedingungen liegen jedoch nur teilweise im Einflussbereich der Umweltbildner(innen). Problematisch sind solche Bedingungen, die sich der Kontrolle der Umweltbildner(innen) entziehen. Hierzu zählen die Planung von Rahmenbedingungen für Bildungsmaßnahmen (z.B. Zeit- und Raumplanung) sowie die Sicherung der Teilnahme von Schulklassen. Die Bedingungen können einen negativen Beitrag auf die Absicht der Umweltbildner(innen), sich am Leitbild zu orientieren, haben und die Leitbildarbeit damit gefährden (ebd.; Helmke, 2009).

$>$ Nach den geführten Einzelinterviews ist anzunehmen, dass die Umweltbildner(innen) überwiegend beabsichtigen, Veranstaltungen nach dem Leitbild $\mathrm{zu}$ entwickeln und umzusetzen. Um die Absicht der Umweltbildner(innen) auch weiterhin fördern zu können, wurden Handlungsempfehlungen entwickelt und an die Heinz Sielmann Stiftung rückgemeldet.

Ein zentraler Schritt der Qualitätsentwicklung der Leitbildarbeit ist eine kritische Überprüfung und Weiterentwicklung des Leitbildes und leitbildbasierter Veranstaltungen im Sinne einer reflexiven Leitbildarbeit (vgl. Giesel, 2007; Helmke, 2009). So wurde eine dritte Teilstudie durchgeführt, um den Umweltbildner(inne)n 
aufzuzeigen, dass ein Leitbild und dessen Umsetzung kontinuierlich überprüft und weiterentwickelt werden müssen (ebd.). Dies wurde exemplarisch am Leitbildziel 5 Systematisches Bewerten verdeutlicht. Das Ziel wurde ausgewählt, weil es auf eine Umsetzung des Kompetenzbereichs Bewertung fokussiert (Fach Biologie, KMK, 2005; Niedersächsisches Kultusministerium, 2007, 2008). Die Erkenntnisse der Teilstudien 1 und 2 gaben Hinweise darauf, dass die Umweltbildner(innen) Schwierigkeiten hatten, Ziel 5 angemessen umzusetzen (vgl. Kapitel 5.1 und 5.2). Um Unterricht zur Vermittlung von Bewertungskompetenz (Eggert \& Bögeholz, 2006; Bögeholz, 2007) optimal unterstützen $\mathrm{zu}$ können, ist eine kritische Reflexion der Leitbildarbeit insbesondere des Ziels 5 Systematisches Bewerten - daher besonders bedeutsam. Folgende Erkenntnisse wurden in Teilstudie 3 erzielt:

Die Umweltbildner(innen) äußern zum einen Schwierigkeiten, Veranstaltungen zur Vermittlung von Bewertungskompetenz didaktisch-methodisch angemessen zu planen und durchzuführen (z.B. nach Helmke, 2009). Sie geben an, insbesondere Schwierigkeiten zu haben, Sachinformationen für Bewertungen aufzubereiten und angemessen einzusetzen.

$>$ Zum anderen geben die Umweltbildner(innen) an, Rahmenbedingungen für Veranstaltungen (z.B. verfügbare Zeit, Raumausstattung) wahrzunehmen, die eine Umsetzung von Bewertung (Eggert \& Bögeholz, 2006; Bögeholz, 2007) erschweren können.

Die Umweltbildner(innen) geben an, grundsätzlich eine positive Einstellung (z.B. nach Ajzen, 2005) gegenüber Bewertungskompetenz (Eggert \& Bögeholz, 2006; Bögeholz, 2007) zu haben. Sie stehen einer Umsetzung an einem außerschulischen Lernort jedoch kritisch gegenüber. Sie geben an, dass eine außerschulische Bildung eine Vermittlung von Bewertungskompetenz in der Schule unterstützen kann, sie jedoch nicht vollkommen ersetzen sollte.

$>$ Die Ergebnisse der Untersuchung wurden zunächst dazu verwendet, ein Modell für eine kooperative Zusammenarbeit von Schule und außerschulischem Lernort zur Vermittlung von Bewertungskompetenz (in Anlehnung an Bögeholz, Bittner \& Knolle, 2006) zu erstellen. In einem nächsten Schritt ist das Modell der Heinz Sielmann Stiftung - insbesondere den Umweltbildner(inne)n - vorzustellen und mit ihnen zu diskutieren.

Im Hinblick auf die Teilziele und Qualitätsmerkmale des Leitbildziels 5 Systematisches Bewerten gaben die Umweltbildner(innen) keine Optimierungs- 
vorschläge an. Aus wissenschaftlicher Perspektive wäre nachträglich jedoch eine Anpassung des Zielbereichs auf praktisch orientierte Komponenten einer Vermittlung von Bewertungskompetenz, z.B. Motivierung durch Naturerfahrungen (Bögeholz, Bittner \& Knolle, 2006; Abbildung 10), denkbar.

Teilstudie 3 betont abschließend die Notwendigkeit, neben der Qualität leitbildbasierter Veranstaltungen auch die Passung von Leitbildbausteinen für den Lernort sowie zum Stand der Forschung im Prozess reflexiver Leitbildarbeit angemessen gewichtet zu berücksichtigen (vgl. hierzu Abbildung 11). Teilstudie 3 trägt damit auch dazu bei, die Theorie zur reflexiven Leitbildarbeit weiterzuentwickeln.

Es konnte gezeigt werden, dass die Teilstudien jeweils dazu beitrugen, unterschiedliche Bereiche einer Qualitätsentwicklung in der leitbildbasierten Biodiversitätsbildung zu untersuchen (vgl. Flick, 2008). Darüber hinaus können die gewonnenen Erkenntnisse einer jeden Teilstudie aber auch dazu genutzt werden, Befunde der anderen beiden Teilstudien zu ergänzen, zu erklären oder zu bestätigen (vgl. Bloor et al., 2001). So ist zum einen anzunehmen, dass die in Teilstudie 2 identifizierten positiven Einschätzungen der Umweltbildner(innen) dazu beitrugen, eine hohe Qualität der Umsetzung des Leitbildes (Teilstudie 1) zu fördern (vgl. z.B. Ostermeier, Prenzel \& Duit, 2009; Helmke, 2009).

Zum anderen geben die Aussagen der Umweltbildner(innen) aus Teilstudie 2 Aufschluss über Defizite, die in Teilstudie 1 festgestellt wurden. So gaben die Umweltbildner(innen) in Teilstudie 2 an, sich nur mangelhaft mit dem Leitbildziel 5 Systematisches Bewerten auseinandergesetzt zu haben (UB1, UB2; vg1. S. 61). Dies kann eine mögliche Erklärung für die in Teilstudie 1 identifizierten Schwierigkeiten in der Umsetzung des Ziels (vgl. S. 41f) und damit ein weiterer Ansatzpunkt für eine Optimierung der Leitbildarbeit sein. Um als Orientierungshilfe wirksam sein zu können, sollten sich die Umweltbildner(innen) zukünftig verstärkt mit den Zielen des Leitbildes, insbesondere mit Ziel 5, auseinandersetzen (vgl. Giesel, 2007), Fragen und Probleme (gemeinsam) klären (vgl. Helmke, 2009) und weitere Erfahrungen in der Umsetzung des Leitbildes sammeln.

Weiterhin können Erklärungen für die in Teilstudie 1 festgestellten Defizite in der Umsetzung von Leitbildzielen durch Erkenntnisse der Teilstudien 2 und 3 untermauert werden. So werden die in Teilstudie 1 aufgezeigten Schwierigkeiten der Umweltbildner(innen), Bildungsmaßnahmen didaktisch-methodisch angemessen (Helmke, 
2009) zu gestalten (vgl. S. 47), bestätigt. Sowohl in Teilstudie 2 (vgl. S. 61) als auch in Teilstudie 3 (vgl. S. 82f) wird die Problematik von den Umweltbildner(inne)n selbst erkannt und angesprochen. Um die Leitbildarbeit optimieren zu können, ist - wie bereits in den Teilstudien aufgezeigt - eine Weiterbildung der Umweltbildner(innen) im Hinblick auf didaktisch-methodische Anforderungen an Bildungsmaßnahmen (ebd.) erforderlich (ebd.; vgl. auch Ostermeier, Prenzel \& Duit, 2009).

Des Weiteren wurde bereits in Teilstudie 1 angenommen, dass eine zu hohe Anzahl angestrebter Qualitätsmerkmale je Veranstaltung (ca. 35 je Modul) die Qualität einer Umsetzung des Leitbildes erschwert (vgl. S. 48). In Teilstudie 2 bestätigen die Umweltbildner(innen) diese Annahme (vgl. S. 61). Um das Leitbild angemessen umsetzen zu können, schlagen sie vor, die Qualitätsmerkmale für eine Veranstaltung zu reduzieren (vgl. S. 61).

Die Umweltbildner(innen) geben weiterhin Rahmenbedingungen (z.B. Zeitressourcen und Raumausstattung) in Teilstudie 2 an, die eine leitbildbasierte Gestaltung von Bildungsmaßnahmen erschweren können (vgl. S. 61). In Teilstudie 3 werden die Bedingungen erneut geäußert (vgl. S. 82). Zudem wird in beiden Teilstudien geschlussfolgert, dass die Zusammenarbeit zwischen Schule und außerschulischem Lernort $\mathrm{zu}$ optimieren ist (vgl. Box 4, S. 66; S. 85ff). Als Konsequenz wurde in Teilstudie 3 ein Modell zur Zusammenarbeit beider Institutionen zur Umsetzung leitbildbasierter Veranstaltungen entwickelt. Eine wechselseitige Unterstützung sowie eine gleichzeitige Nutzung lernortspezifischer Stärken kann so gefördert werden (Abbildung 10, S. 85ff; vgl. auch Bögeholz, Bittner \& Knolle, 2006). Dabei kann eine systematische Zusammenarbeit auch dazu dienen, Rahmenbedingungen zu erleichtern. Beispielsweise können so der Zeitaufwand und eine benötigte Raumausstattung je Veranstaltung lernortspezifisch abgestimmt werden.

Abschließend ist festzuhalten, dass durch eine Verzahnung der Einzelstudien miteinander, Erkenntnisse erweitert und bekräftigt werden können. Darüber hinaus können weitere Ansatzpunkte für eine Optimierung der Leitbildarbeit aufgezeigt werden. Damit ist eine Zusammenführung von Erkenntnissen aus den Einzeluntersuchungen im Rahmen einer umfassenden formativen Evaluation unerlässlich (z.B. von Kardorff, 2008; Flick, 2008). 
Kritische Würdigung des methodischen Ansatzes

Nachdem in den vorangegangenen Abschnitten die Erkenntnisse der Teilstudien aufgezeigt wurden, werden im Folgenden die gewählten methodischen Vorgehensweisen diskutiert. Handlungsleitend waren dabei zunächst die Vorgaben der Deutschen Gesellschaft für Evaluation handlungsleitend (DeGEval, 2005):

- So wurden alle drei Teilstudien zweckorientiert eingesetzt. Ziel war es, die Qualität der Biodiversitätsbildung zu entwickeln. Hierzu trugen die Teilstudien 1-3 bei (oben).

- Die Studien wurden zweckorientiert geplant und ausgeführt. Dabei wurde methodisch kontrolliert versucht, möglichst objektive, valide und reliable Ergebnisse zu gewinnen (siehe unten).

- Alle Beteiligten wurden respektvoll und fair behandelt. Dabei wurden Daten stets anonymisiert verwendet. Die Umweltbildner(innen) wurden als gleichberechtigte Partner(innen) am Projekt beteiligt. In Anlehnung an die symbiotische Implementationsstrategie nach Gräsel und Parchmann (2004; Parchmann et al., 2006) konnte so eine forschungsbasierte und dennoch praxisorientierte Entwicklungsarbeit durchgeführt, Akzeptanzprobleme minimiert und die Absicht der Umweltbildner(innen), das Leitbild mitzuentwickeln und angemessen umzusetzen, gefördert werden (Gräsel \& Parchmann, 2004; Parchmann et al., 2006; Giesel, 2007; vgl. Kapitel 4.1).

Für einen möglichst ganzheitlichen Untersuchungsansatz orientierte sich die Studie weiterhin am Prinzip der Triangulation für qualitative Forschung (Flick, 2008; Denzin, 1989). Somit wurden berücksichtigt:

- Daten verschiedener Quellen mit unterschiedlichen Messzeitpunkten; siehe hierzu Protokolle externer Beobachtungen, Transkripte der Einzelinterviews mit den Umweltbildner(inne)n, Transkripte der Fokusgruppen mit den Umweltbildner(inne)n im Anhang,

- verschiedene theoretische Grundlagen wie Leitbilder nach Giesel (2007) und Theory of Planned Behavior nach Ajzen (2005, 2008),

- unterschiedliche methodische Vorgehensweisen wie nicht-teilnehmende Beobachtung nach Bortz \& Döring (2006); problemzentrierte Einzelinterviews nach Mayring (2002) und Fokusgruppen nach u. a. Bryman (2004) sowie 
- Auswertungen durch mehrere Personen (Unterstützung durch Examens- und Masterkandidat(inn)en; vgl. Stiel, (2007; Mackensen, 2007; Czech, 2008), um subjektive Einflüsse zu reduzieren.

Für die Leitbildfestlegung in Teilstudie 1 wurde zunächst eine Fokusgruppe (Morgan, 1998; Bryman, 2004) mit den beteiligten Umweltbildner(inne)n durchgeführt. Für eine Überprüfung der Umsetzung des Leitbildes wurden nicht-teilnehmende Beobachtungen (z.B. Diekmann, 2007) eingesetzt. Der Einsatz einer Fokusgruppe bot im Rahmen der Teilstudie 1 zum einen eine Möglichkeit, ein gemeinsames Verständnis über die Bildungsfoki des erarbeiteten wissenschaftlichen Fundaments (vgl. Tabelle 2) zu gewinnen (vgl. Morgan, 1998; Bryman, 2004). Zum anderen diente die Methode dazu, zielgerichtet Ziele, Teilziele und Qualitätsmerkmale für ein Leitbild abzustimmen. Alle Umweltbildner(innen) erhielten dabei die Gelegenheit, ihre Meinungen, Ideen und Wünsche einzubringen, die Standpunkte der anderen zu diskutieren und zu ergänzen (ebd.).

Dennoch kann eine Fokusgruppe individuelle Meinungen nur bedingt berücksichtigen. Es ist anzunehmen, dass vor allem solche Ansichten geäußert wurden, die von den Umweltbildner(inne)n als sozial verträglich eingeschätzt wurden. Abweichende Annahmen wurden wahrscheinlich eher selten genannt (Morgan, 1997; Morgan, 1998).

Nicht-teilnehmende Beobachtungen dienten dazu, die Qualität der Umsetzung des Leitbildes in neuen Veranstaltungen einzuschätzen (Diekmann, 2007; Bortz \& Döring, 2006). Die Durchführung der Beobachtungen durch eine externe Person (wissenschaftliche Begleitung) trug dazu bei, die Objektivität von Untersuchungsergebnissen zu erhöhen (Kempfert \& Rolff, 2005). Die evaluierende Person nahm selbst nicht an der Veranstaltung teil. Sie konnte sich somit ausschließlich auf die Evaluation konzentrieren (Diekmann, 2007). Die gewonnenen Ergebnisse wurden an die Umweltbildner(innen) rückgemeldet. Sie stellten die Grundlage für gemeinsame Optimierungsmaßnahmen von Veranstaltungen dar (Kuckartz et al., 2008; Schratz, 2003).

Mit nicht-teilnehmenden Beobachtungen können die sichtbaren Komponenten einer Umsetzung des Leitbildes erfasst werden (Bortz \& Döring, 2006). Subjektive Entscheidungen der Umweltbildner(innen) als zentrale Bedingung für die Qualität der Leitbildarbeit (z.B. Ostermeier, Prenzel \& Duit, 2009; Helmke, 2009) können durch Beobachtungen jedoch kaum zufriedenstellend - da nur indirekt erschließbar - 
untersucht werden (Bortz \& Döring, 2006). Um im Rahmen der Evaluationsstudie auch die persönlichen Einschätzungen der Umweltbildner(innen) berücksichtigen zu können, wurde eine zweite Teilstudie durchgeführt. In dieser Studie wurden problemzentrierte Einzelinterviews (Mayring, 2002) eingesetzt. Einzelinterviews ermöglichten den Umweltbildner(inne)n, ihre individuellen Standpunkte zu äußern. Im Gegensatz zur Fokusgruppe konnten im Einzelinterview auch solche Einschätzungen geäußert werden, welche die Umweltbildner(innen) voraussichtlich nicht in der gesamten Gruppe explizieren würden (Morgan, 1998; Bortz \& Döring, 2006). Da Erfahrungen in der Leitbildarbeit die Entscheidung der Umweltbildner(innen), Veranstaltungen nach dem Leitbild zu gestalten, beeinflussen können (Ajzen, 2005, 2008; Graf, 2007), wurden die Interviews jeweils im Anschluss an mindestens 3 Umsetzungen eines Moduls durch eine(n) Umweltbildner(in) durchgeführt. Theoriegeleitet durch die Theory of Planned Behavior (TOPB; Ajzen, 2005, 2008) konnten sowohl die Erhebungen als auch eine Auswertung in Anlehnung an die Qualitative Inhaltsanalyse nach Mayring (2008) zielgerichtet geplant und durchgeführt werden. Durch eine halboffene Anlage der Studie konnten zudem Aussagen in die Auswertung einfließen, welche die theoretischen Vorgaben ergänzten (deduktiv-induktive Vorgehensweise; vgl. Mayring, 2008). Der qualitative Forschungsansatz trug dazu bei, explorativ Einblicke in die Einschätzungen der Umweltbildner(innen) zu gewinnen (ebd.; Bortz \& Döring, 2006), die - im Sinne einer formativen Evaluation - als Ansatzpunkte für eine Optimierung der Leitbildarbeit genutzt werden konnten (z.B. Helmke, 2009).

Der gewählte methodische Ansatz (Mayring, 2002, 2008) in Teilstudie 2 birgt jedoch auch Schwächen. So muss zum einen angenommen werden, dass sozial erwünschte Antworttendenzen (Bortz \& Döring, 2006; Frey, Stahlberger \& Gollwitzer, 2001) den Wahrheitsgehalt von Interviewaussagen beeinflussten. Inwieweit die Aussagen den tatsächlichen Einschätzungen der Umweltbildner(innen) entsprachen, kann in dieser Untersuchung lediglich vermutet werden. Alternativ zu mündlichen Befragungen hätten anonyme schriftliche Befragungen dazu beitragen können, die Wahrscheinlichkeit sozial erwünschter Antworten zu reduzieren (Bortz \& Döring, 2006).

Auch der Einsatz der Theory of Planned Behavior (Ajzen, 2005, 2008) an sich ist zu hinterfragen. Die Gültigkeit der Theorie (ebd.) ist begrenzt. So konnte die Untersuchung Aussagen über bewusstes, geplantes, aber nicht über unbewusstes, spontanes Verhalten erfassen (Ajzen, 2005; Frey, Stahlberger \& Gollwitzer, 2001). Des Weiteren bleibt 
unklar, inwieweit die Theorie alle zentralen Parameter einer Absicht, sich am Leitbild $\mathrm{zu}$ orientieren, abbildet. Anlass $\mathrm{zu}$ diesem Zweifel geben Untersuchungen u. a. von Beck \& Ajzen (1991; Conner \& Abraham, 2001; vgl. hierzu auch Erten, 2000).

Zudem bleibt ungeklärt, welche Konstrukte der Theorie einen großen bzw. welche nur einen geringen Einfluss auf die Absicht der Umweltbildner(innen) hatten (vgl. z.B. Okun \& Sloane, 2002) und inwieweit sich die theoretischen Konstrukte in diesem Fall wechselseitig beeinflussten (vgl. Ajzen, 2005, 2008). Entsprechend müssen im Rahmen einer formativen Evaluation alle Konstrukte gleichermaßen bei Optimierungsmaßnahmen berücksichtigt werden.

Im Anschluss an die Teilstudien 2 und 3 wurde eine zweite Fokusgruppe (Morgan, 1998; Bryman, 2004) mit den Umweltbildner(inne)n durchgeführt, um die bisherige Umsetzung des Leitbildes zu reflektieren und für zukünftige Veranstaltungen gemeinsam zu optimieren. Jede(r) Umweltbildner(in) konnte seine/ihre Erfahrungen und Optimierungsvorschläge zur Diskussion stellen, Optimierungsarbeiten gemeinsam mit den anderen festlegen und somit an der Leitbildausgestaltung aktiv teilhaben (vgl. Giesel, 2007; Gräsel \& Parchmann, 2004). Die Diskussion in der Fokusgruppe trug dazu bei, den Umweltbildner(inne)n aufzuzeigen, wie sie eine Reflexion und Weiterentwicklung der Leitbildarbeit gemeinsam als Team gestalten können, sich dabei gegenseitig zu unterstützen und wertzuschätzen (vgl. Funktionen eines Leitbildes in Kapitel 2.1; Giesel, 2007). Damit konnte eine fortwährende Qualitätsentwicklung einer leitbildbasierten Bildungsarbeit zu Biodiversität - insbesondere im Hinblick auf eine Umsetzung des bestehenden Leitbildes - angeregt werden (vgl. Burkhard \& Eikenbusch, 2000).

Dennoch konnte die durchgeführte Fokusgruppe nicht dazu beitragen, eine konkrete Weiterentwicklung von Leitbildzielen, Teilzielen und Qualitätsmerkmalen zu initiieren. Eine gezielte Diskussionsführung hierzu erfolgte nur unzureichend. Nachträglich konnten allein aus wissenschaftlicher Sicht Optimierungsvorschläge vorgestellt werden. Für eine zukünftige reflexive Leitbildarbeit ist die Gesprächsführung - und damit insbesondere der für die Untersuchung verwendete Interviewleitfaden - so zu modifizieren, dass sowohl die Qualität von Leitbildveranstaltungen als auch die Passung von Leitbildbausteinen für den Lernort und zum Stand der Forschung jeweils angemessen gewichtet in den Prozessen Reflexion und Weiterentwicklung (vgl. Abbildung 11) berücksichtigt werden. 
Abschließend ist zu betonen, dass die durchgeführten Teilstudien 1, 2 und 3 lediglich eine „Momentaufnahme“ in der Qualitätsentwicklung der Biodiversitätsbildung der Heinz Sielmann Stiftung darstellen können. Teilstudie 1 konnte dabei einen ersten Einblick in den Stand der Qualität von Leitbildumsetzungen geben. Weitere Umsetzungsmessungen sind nötig, um zu klären, inwieweit die Qualität weiterhin gesteigert werden kann. Auch Teilstudie 2 stellt einen ersten Stand der Einschätzungen der Umweltbildner(innen) dar. Um zu untersuchen, inwieweit sich ihre Einschätzungen, sich am Leitbild zu orientieren, entwickeln, sind weitere Analysen - im Sinne von Langzeitmessungen (vgl. Bortz \& Döring, 2006) - notwendig. Teilstudie 3 stellt exemplarisch einen ersten Schritt in der optimierenden Weiterentwicklung der Leitbildarbeit dar. Somit trug die Evaluationsstudie dazu bei, eine Qualitätsentwicklung der Biodiversitätsbildung anzustoßen, Möglichkeiten einer kontinuierlichen Überprüfung und Optimierung aufzuzeigen und damit eine Evaluationskultur - im Sinne reflexiver Leitbildarbeit - in der Biodiversitätsbildung der Heinz Sielmann Stiftung anzuregen (Schratz, 2003; Burkhard \& Eikenbusch, 2000).

Für eine zukünftige Qualitätsentwicklung nach der wissenschaftlichen Begleitung wird zentral sein, nicht nur das Bildungsangebot an sich zu fokussieren, sondern auch die Umweltbildner(innen) systematisch fortzubilden und Rahmenbedingungen des Lernortes zu optimieren (vgl. Helmke, 2009; Ostermeier, Prenzel \& Duit, 2009). Ferner ist $\mathrm{zu}$ überlegen, wie eine interne Evaluation ausgestaltet werden kann (Kempfert \& Rolff, 2005). Beispielsweise könnten die Umweltbildner(innen) gemeinsam Veranstaltungen entwickeln, umsetzen und ihre Umsetzungen wechselseitig beobachten (vgl. hierzu Helmke, 2009). Der Heinz Sielmann Stiftung wurde hierfür der in Teilstudie 1 verwendete Beobachtungsleitfaden zur Verfügung gestellt. Dieser lässt sich auf die spezifischen Bedürfnisse der Umweltbildner(innen) anpassen. Nachdem zunächst ein inhaltlicher Fokus in der Leitbildarbeit erfolgte, könnten nun auch methodische Aspekte stärker berücksichtigt werden. So wäre eine Erweiterung des Leitfadens um didaktisch-methodische Anforderungen (ebd.) an Bildungsmaßnahmen denkbar. Zudem kann die Anzahl von Qualitätsmerkmalen je Veranstaltung von den Umweltbildner(inne)n selbst bestimmt werden. Sie können damit selbst festlegen, wie viele Qualitätsmerkmale sie in einer Veranstaltung zum einen als erfüllbar und zum anderen als beobachtbar erachten und somit selbstbestimmt entscheiden, inwieweit das 
Leitbild als Orientierungsrahmen in Veranstaltungen wirksam sein soll (vgl. Giesel, 2007).

Für eine kontinuierliche Weiterentwicklung des Leitbildes sowie leitbildbasierter Veranstaltungen können regelmäßige gemeinsame Treffen der Umweltbildner(innen) hilfreich sein (vgl. Helmke, 2009). Wie in Teilstudie 3 exemplarisch aufgezeigt, könnten die Umweltbildner(innen) das Leitbild sowie dessen Umsetzung kritisch überprüfen und weiterentwickeln. Dabei sollte - entgegen der Vorgehensweise in Teilstudie 3 - neben Optimierungsvorschlägen von Umsetzungen auch konkret geklärt werden, inwieweit einzelne Ziele, Teilziele und Qualitätsmerkmale fortgeführt oder verändert werden müssen (vgl. Giesel, 2007).

$\mathrm{Zu}$ überlegen ist weiterhin, inwieweit Wirksamkeitsmessungen bei Schüler(inne)n im Sinne einer summativen Evaluation (vgl. Wottawa \& Thierau, 2003) zukünftig im Rahmen einer internen Beurteilung eine Rolle spielen sollen. Diese Informationen könnten weitere Hinweise für eine optimierende Weiterentwicklung des leitbildbasierten Bildungsangebots liefern und einer kontinuierlichen Qualitätsentwicklung somit zusätzlich beitragen (ebd.; Schratz, 2003; Kempfert \& Rolff, 2005). Schriftliche Befragungen von Schüler(inne)n, die an einer leitbildbasierten Veranstaltung teilnehmen, könnten hierfür vorbereitet und eingesetzt werden (vgl. Bortz \& Döring, 2006).

Damit stellt die vorliegende Evaluationsstudie einen ersten Schritt zur Qualitätsentwicklung außerschulischer Biodiversitätsbildung dar, den es zukünftig weiter zu gestalten gilt. Die Studie trug dazu bei, Stärken und Schwächen in der Ausgestaltung eines Leitbildes für die Heinz Sielmann Stiftung sowie leitbildbasierter Veranstaltungen umfassend, multiperspektivisch zu identifizieren und systematisch für Optimierungsarbeiten zu nutzen. Für einen Übergang des Evaluationsprojektes in eine interne Ausgestaltung von Evaluationsmaßnahmen wurden denkbare nächste Schritte aufgezeigt. Inwieweit eine Umsetzung der Vorschläge erfolgen wird, bleibt durch die Heinz Sielmann Stiftung zu entscheiden. 


\section{Literaturverzeichnis}

Ahlf-Christiani, C., Dierks, H.-G., von Gadow, F., Hübner, K.-D., Malm, W.-U., Schulz, P. \& Warning-Schröder, H. (2003). Förderung der Urteilskompetenz im Fachunterricht der Sekundarstufe I und II. Werkstattmaterialien Bildung für eine Nachhaltige Entwicklung, Partizipatives Lernen - Nachhaltigkeitsindikatoren entwickeln. Online verfügbar unter: http://www.dekade.org/transfer_21/wsm/09.pdf (abgerufen am 26. Januar 2009).

Ajzen, I. (2008). Perceived Behavioral Control, Self-Efficacy, Locus of Control, and the Theory of Planned Behavior. Journal of Applied Social Psychology, 32 (4), 665-683.

Ajzen, I. (2005). Attitudes, personality, and behaviour. Milton-Keynes, England: Open University Press.

Ajzen, I. (1985). Form Intentions to Actions: A Theory of Planned Behavior. In J. Kuhl \& J. Beckmann (Hrsg.), Action Control. Berlin u. a.: Springer, 11-39.

Aronson, E. (1984). Förderung von Schulleistung, Selbstwert und prosozialem Verhalten: Die Jigsaw-Methode. In G. L. Huber, S. Rotering-Steinberg \& D. Wahl (Hrsg.), Kooperatives Lernen. Weinheim, Basel: Beltz, 48-60.

Ballentyne, R., Conell, S. \& Fien, J. (2007). Conservation learning in wildlife tourism settings: lessons from research in zoos and aquariums. Environmental Education Research, 13 (3), 367-383.

Bauer, N., Wasem, K. \& Hunziker, M. (2004). Wildnis in der Schweiz - Eine qualitative Studie über die Einstellungen $\mathrm{zu}$ Verwilderung und zur Ausweisung neuer Wildnisgebiete. Umweltpsychologie, 8 (2), 102-123.

Bayrhuber, H., Bögeholz, S., Eggert, S., Elster, D., Grube, C., Hößle, C., Linsner, M., Lücken, M., Mayer, J., Möller, A., Nerdel, C., Neuhaus, B., Prechtl, H., Sandmann, A., Mittelsten Scheid, N., Schmiemann, P. \& Schoormans, G. (2007). Biologie im Kontext (bik) - Ein Programm zur Kompetenzförderung durch Kontextorientierung im Biologieunterricht und zur Unterstützung von Lehrerprofessionalisierung, Mathematisch Naturwissenschaftlicher Unterricht, 60 (5), 304-313.

Beck, L. \& Ajzen, I. (1991). Predicting dishonest actions using the theory of planned behaviour. Journal of Research in Personality, 25 (3), 285-301. 
Blömeke, S., Eichler, D. \& Müller, C. (2003). Rekonstruktion kognitiver Strukturen von Lehrpersonen als Herausforderung für die empirische Unterrichtsforschung. Unterrichtsforschung, 31 (2), 103-121.

Bloor, M., Frankland, J., Thomas, M. \& Stewart, K. (2001). Focus Groups in Social Research. London: Sage.

Bögeholz, S. (2007). Bewertungskompetenz für systematisches Entscheiden in komplexen Gestaltungssituationen Nachhaltiger Entwicklung. In D. Krüger \& H. Vogt (Hrsg.), Theorien in der biologiedidaktischen Forschung. Ein Handbuch für Lehramtsstudenten und Doktoranden. Berlin, Heidelberg: Springer, 209-220.

Bögeholz, S. (2006a). Explizites Bewerten und Urteilen. Beispielkontext Streuobstwiese. Praxis der Naturwissenschaften - Biologie, 55 (1), 17-24.

Bögeholz, S. (2006b). Nature Experience and its Importance for Environmental Knowledge, Environmental Values and Environmental Action - Recent German Empirical Contributions. Environmental Education Research, 12 (1), 65-84.

Bögeholz, S. (2005). Lern- und Schulbauernhöfe und ihre Potentiale für Bildung für Nachhaltige Entwicklung. Überland, 13 (1), 3-9.

Bögeholz, S. (2001). Sinnliche Gewissheit. Naturerfahrungen im Schulgarten als Ausgangspunkt für Wissen, Bewerten und Handeln. Umwelt \& Bildung, 1/2001, 2627.

Bögeholz, S. (1999). Qualitäten primärer Naturerfahrung und ihr Zusammenhang mit Umweltwissen und Umwelthandeln. Opladen: Budrich und Leske.

Bögeholz, S. \& Barkmann, J. (2005). Rational choice and beyond: Handlungsorientierende Kompetenzen für den Umgang mit faktischer und ethischer Komplexität. In R. Klee, A. Sandmann \& H. Vogt (Hrsg.), Lehr- und Lernforschung in der Biologiedidaktik. Innsbruck, Wien, Bozem: Studienverlag, 211-224.

Bögeholz, S. \& Barkmann, J. (2003). Ökologische Bewertungskompetenz für reale Entscheidungssituationen: Gestalten bei faktischer und ethischer Komplexität. $D G U$ Nachrichten, 27/28, 44-53. 
Bögeholz, S., Bittner, A. \& Knolle, F. (2006). Der Nationalpark Harz als Bildungsort. Vom Naturerleben zur Bildung für eine Nachhaltige Entwicklung. GAIA, 15 (2), 135 143.

Bögeholz, S., Hößle, C., Langlet, J., Sander, F. \& Schlüter, K. (2004). BewertenUrteilen - Entscheiden im biologischen Kontext. Modelle in der Biologiedidaktik. Zeitschrift für Didaktik der Naturwissenschaften, 10, 89-115.

Bögeholz, S. \& Rüter, S. (2004). Wenn Erfahrung weh tut - The dark side of nature experience. In H. Großengießer, A. Janßen-Bartels, \& E. Sander (Hrsg.), Lehren fürs Leben. Köln: Aulis Verlag Deubner.

Bögeholz, S., Stelte, W. \& Säger, U. (2005). Forschungsbasierte Umweltbildung. Der umweltpädagogische Ansatz der Heinz Sielmann Stiftung (Heinz Sielmann Stiftung). Deutsche Stiftungen. Mitteilungen des Bundesverbandes deutscher Stiftungen. Lebensräume - Stiftungen investieren in die Zukunft, 1, 8-9.

Bolscho, D. \& Hauenschild, K. (2006). From environmental education to Education for Sustainable Development in Germany. Environmental Education Research, 12 (1), 7 18.

Bormann, I. \& de Haan, G. (Hrsg.) (2008). Kompetenzen der Bildung für Nachhaltige Entwicklung. Wiesbaden: VS Verlag.

Bortz, J. \& Döring, N. (2006). Forschungsmethoden und Evaluation für Human- und Sozialwissenschaftler. Berlin: Springer.

Bryman, A. (2004). Social Research Methods. Oxford, New York: University Press.

Bundesministerium für Bildung und Forschung (BMBF) (2006). Forschung für die Nachhaltigkeit. Rahmenprogramm des BMBF für eine zukunftsfähige innovative Gesellschaft. Bonn, Berlin: BMBF.

Bundesministerium für Bildung und Forschung (BMBF) (2002). Bericht der Bundesregierung zur Bildung für eine Nachhaltige Entwicklung. Bonn: BMBF.

Bundesministerium für Umwelt, Naturschutz und Reaktorsicherheit (BMU) (2007). Nationale Strategie zur biologischen Vielfalt. Berlin: BMU.

Bundesministerium für wirtschaftliche Zusammenarbeit und Entwicklung, Kultusministerkonferenz (BMZ/KMK) (2007). Orientierungsrahmen für den 
Lernbereich Globale Entwicklung. Online verfügbar unter: http://www.bneportal.de/coremedia/generator/unesco/de/Downloads/Hintergrundmaterial_national/ Orientierungsrahmen_20f_C3_BCr_20den_20Lernbereich_20Globale_20Entwicklun g.pdf (abgerufen am 13. März 2009).

Burkhard, C. \& Eikenbusch, G. (2000). Praxishandbuch Evaluation in der Schule. Berlin: Cornelsen.

Bybee, R. W. (2004). Scientific Inquiry and Science Teaching. In L. B. Flick \& N. G. Lederman (Eds.), Scientific Inquiry and Nature of Science. Implications for Teaching, Learning and Teacher Education. Dordrecht, Boston, London: Kluwer Academic Publishers.

Conein, S. (2000). Umweltbildung an Reformschulen - Leitbildanalysen an Montessoriund Waldorfschulen. Berlin: Logos.

Conner, M. \& Abraham, C. (2001). Conscientiousness and the theory of planned behavior: Toward a more complete model of the antecedents of intentions and behavior. Personality and Social Psychology Bulletin, 27, 1547-1561.

Convention on Biological Diversity (CBD) (1992). Concluded at Rio de Janeiro on 5 June 1992. Online available at: http://www.cbd.int/doc/legal/cbd-un-en.pdf (accessed on 26 January 2009).

Cotton, D.R.E. (2006). Implementing curriculum guidance on environmental education: the importance of teachers's beliefs. Journal of Curriculum Studies, 38 (1), 67-83.

Czech, C. (2008). Schärfung eines Leitbildes zur Biodiversitätsbildung der Heinz Sielmann Stiftung. Examensarbeit an der Georg-August-Universität Göttingen.

De Haan, G. (2006). Bildung für Nachhaltige Entwicklung - ein neues Lern- und Handlungsfeld, UNESCO heute, 1, 4-8.

De Haan, G. (2005). Die Kernthemen der Bildung für eine Nachhaltige Entwicklung. Online verfügbar unter: http://www.transfer-21.de/daten/texte/kernthemen.pdf (abgerufen am 01. Februar 2006).

De Haan, G. \& Harenberg, D. (1999). Bildung für eine Nachhaltige Entwicklung. Bonn: Bund-Länder-Kommission für Bildungsplanung und Forschungsförderung (BLK). 
De Haan, G., Kamp, G., Lerch, A., Martignon, L., Müller-Christ, G. \& Nutzinger, H.-G. (2008). Nachhaltigkeit und Gerechtigkeit. Grundlagen und schulpraktische Konsequenzen. Berlin, Heidelberg: Springer.

Denzin, N. K. (1989). The Research Act. A Theoretical Introduction to Sociological Methods. Englewood Cliffs: Prentice Hall.

Deutsche Gesellschaft für Evaluation (DeGEval) (2005). Standards für Evaluation. Online verfügbar unter: http://www.degeval.de/calimero/tools/proxy.php?id=19076 (abgerufen am 26. März 2009).

Deutsche UNESCO-Kommission e.V. / Nationalkomitee UN-Dekade „Bildung für Nachhaltige Entwicklung“ (2008). Nationaler Aktionsplan für Deutschland. UNDekade Bildung für Nachhaltige Entwicklung 2005-2014. Online verfügbar unter: http://www.bne-portal.de/coremedia/generator/unesco/de/Downloads/Dekade __Publikationen_national/Der_20Nationale_20Aktionsplan_20f_C3_BCr_20Deutsc hland_202009.pdf (abgerufen am 26. Januar 2009).

Diekmann, A. (2007). Empirische Sozialforschung. Grundlagen, Methoden, Anwendungen. Reinbek: Rowohlt.

Diemer, M., Held, M. \& Hofmeister, S. (2004). Stadtwildnis - Konzepte, Projekte und Perspektiven. GAIA, 13 (4), 262-270.

Eagly, A. H. \& Chaiken, S. (1998). Attitude structure and function. In D. Gilbert, S. T. Fiske \& G. Lindzey (Eds.), Handbook of social psychology. New York: McGrawHill, 269-322.

Eggert, S. \& Bögeholz, S. (2006). Göttinger Modell der Bewertungskompetenz - Teilkompetenz "Bewerten, Entscheiden und Reflektieren" für Gestaltungsaufgaben Nachhaltiger Entwicklung. Zeitschrift für Didaktik der Naturwissenschaften, 12, 177-197.

Eggert, S. \& Hößle, C. (2006). Bewertungskompetenz im Biologieunterricht. Ein Überblick. Praxis der Naturwissenschaften. Biologie, 55 (1), 1-10.

Erten, S. (2000). Empirische Untersuchungen zu Bedingungen der Umwelterziehung ein interkultureller Vergleich auf der Grundlage der Theorie des geplanten Verhaltens. Marburg: Tectum. 
Eschenhagen, D., Kattmann, U. \& Rodi, D. (2008). Fachdidaktik Biologie. Köln: Aulis Verlag Deubner.

Euler, D. \& Sloane, P. F. E. (1998). Implementation als Problem der Modellversuchsforschung. Unterrichtswissenschaft, 26 (4), 312-326.

Flick, U. (2008). Triangulation in der qualitativen Forschung. In U. Flick, E. von Kardorff \& I. Steinke (Hrsg.), Qualitative Forschung. Ein Handbuch. Reinbek: Rowohlt Taschenbuch Verlag, 309-331.

Frey, D., Stahlberg, D. \& Gollwitzer, P. (2001). Einstellung und Verhalten: Die Theorie des überlegten Handelns und die Theorie des geplanten Verhaltens. In D. Frey \& M. Irle (Hrsg.) Theorien der Sozialpsychologie. Band I: Kognitive Theorien, Bern u. a.: Verlag Hans Huber, 361-398.

Ganz, W. \& Graf, N. (2007). Notwendigkeit und Grundidee von PerformanzLeitbildern. In W. Ganz \& N. Graf (Hrsg.), Performanz-Leitbilder. Ergebnisse einer Breitenerhebung zu Leitbildern in der betrieblichen Praxis. Stuttgart: Fraunhofer IRB Verlag, 4-7.

Gayford, C. (2000). biodiversity education: a teacher's perspective. Environmental Education Research, 6 (4), 347-361.

Geyer, S. (2003). Forschungsmethoden in den Gesundheitswissenschaften. Eine Einführung in die empirischen Grundlagen. Weinheim, München: Juventa.

Giesel, K. D. (2007). Leitbilder in den Sozialwissenschaften. Begriffe, Theorien und Forschungskonzepte. Wiesbaden: VS Verlag.

Götz, K. \& Häfner, P. (2004). Didactic organization of teaching and learning processes: a textbook for schools and adult education. Frankfurt: Lang.

Grace, M. (2008). Developing High Quality Decision-making Discussions about Biological Conversation in a Normal Classroom Setting, International Journal of Science Education, 30 (1), 1-20.

Graf, D. (2007). Die Theorie des geplanten Verhaltens. In D. Krüger \& H. Vogt (Hrsg.) Theorien in der biologiedidaktischen Forschung. Ein Handbuch für Lehramtsstudenten und Doktoranden. Berlin, Heidelberg: Springer, 33-43.

Graf, P. \& Sprengler, M. (2000). Leitbild- und Konzeptentwicklung. Augsburg: Ziel. 
Gräsel, C. \& Parchmann, I. (2004). Implementationsforschung: Der steinige Weg, Unterricht zu verändern. Unterrichtswissenschaft, 33, 196-213.

Gropengießer, H. (2001). Didaktische Rekonstruktion des "Sehens": wissenschaftliche Theorien und die Sicht der Schüler in der Perspektive der Vermittlung. Oldenburg: Carl-von-Ossietzky-Universität.

Große, F. \& Bögeholz, S. (2005). Explizite Bewertung am Beispiel der Streuobstwiese - Zur Bedeutung von Entscheidungs- und Ökosystemkontexten. In M. Schrenk \& W. Holl-Giese (Hrsg.), Bildung für Nachhaltige Entwicklung. Ergebnisse empirischer Untersuchungen. Hamburg: Verlag Dr. Kovač, 159-173.

Hammann, M. (2005). Wissensvoraussetzungen bei problemorientierten Vergleichen in der Ökologie. In R. Klee, H. Bayrhuber \& A. Sandmann (Hrsg.), Lehr- und Lernforschung in der Biologiedidaktik. Innsbruck: Studienverlag, 11-27.

Hammann, M. (2004). Kompetenzentwicklungsmodelle: Merkmale und ihre Bedeutung - dargestellt anhand von Kompetenzen beim Experimentieren, Mathematisch Naturwissenschaftlicher Unterricht, 57 (4), 196-203.

Harms, U., Mayer, J., Hammann, M., Bayrhuber, H. \& Kattmann, U. (2004). Kerncurriculum und Standards für den Biologieunterricht. In E. Tenorth (Hrsg.) Kerncurriculum Oberstufe II. Weinheim, Basel: Beltz.

Hasselhorn, M. \& Gold, A. (2006). Pädagogische Psychologie. Erfolgreiches Lernen und Lehren. Stuttgart: Kohlhammer.

Helmke, A. (2009). Unterrichtsqualität und Lehrerprofessionlalität. Diagnose, Evaluation und Verbesserung des Unterrichts. Seelze: Kallmeyersche Verlagsbuchhandlung.

Höttecke, D. (2001). Die Vorstellungen von Schülern und Schülerinnen von der „Natur der Naturwissenschaften“. Zeitschrift für Didaktik der Naturwissenschaften, 7, 7-23.

Kempfert, G. \& Rolff, H.-G. (2005). Qualität und Evaluation. Ein Leitfaden für Pädagogisches Qualitätsmanagement. Weinheim, Basel: Beltz.

Klein, M. \& Ssymank, A. (1995). Biodiversität und Naturschutz. Teil 1: Die Bedeutung der genetischen Diversität. Biologie in der Schule, 44 (1), 53-55. 
Krueger, R. A. \& Casey, M. A. (2000). Focus groups. A practical guide for applied research. Thousand Oaks, London, New Delhi: Sage.

Kuckartz, U., Dresing, T., Rädiker, S. \& Stefer, C. (2008). Qualitative Evaluation. Der Einstieg in die Praxis. Wiesbaden: VS Verlag.

Kultusministerkonferenz (KMK; Hrsg.) (2005). Bildungsstandards im Fach Biologie für den Mittleren Schulabschluss. Beschluss vom 16.12.2004. München: Luchterhand.

Langenhorst, B. (2005). Waldscout \& Waldranger. Naturbildung im Nationalpark Kellerwald-Edersee unter dem Leitbild Nachhaltiger Entwicklung. Unterricht Biologie, 29, 18-22.

Lindemann-Matthies, P. (2002). Vielfalt am Schulweg. In Umweltdachverband (Hrsg.) Leben in Hülle und Fülle. Vielfältige Wege zur Biodiversität. Wien: Forum Umweltbildung, 40-44.

Lindemann-Matthies, P., Constantinou, C., Junge, X., Köhler, K., Mayer, J., Nagel, U., Raper, G., Schüler, D. \& Kadji-Beltran, C. (2009). The integration of biodiversity education in the initial education of primary school teachers: four comparative case studies from Europe. Environmental Education Research, 15 (1), 17-37.

Lundegard, I. \& Wickman, P.-O. (2007). Conflicts of interest: an indispensable element of education for Sustainable Development. Environmental Education Research, 13 (1), 1-15.

Mackensen, S. (2007). Bewertung als ein möglicher Zielbereich der Biodiversitätsbildung in der Heinz Sielmann Stiftung. Masterarbeit an der GeorgAugust-Universität Göttingen.

Martinetz, S. \& Köhler, S. (2007). Unternehmensleitbilder - mehr Wunsch als Wirksamkeit. In W. Ganz \& N. Graf (Hrsg.), Performanz-Leitbilder. Ergebnisse einer Breitenerhebung zu Leitbildern in der betrieblichen Praxis. Stuttgart: Fraunhofer IRB Verlag, 17-22.

Mayer, J. (1996). Biodiversitätsforschung als Zukunftsdisziplin. Ein Beitrag der Biologiedidaktik, Berichte für das Institut für Didaktik der Biologie, 5, 19-41. 
Mayer, J., Harms, U., Hammann, M., Bayrhuber, H. \& Kattmann, U. (2004). Kerncurriculum Biologie der gymnasialen Oberstufe. Mathematisch Naturwissenschaftlicher Unterricht, 57 (3), 166-173.

Mayring, P. (2008). Qualitative Inhaltsanalyse. Weinheim: Beltz.

Mayring, P. (2002). Empirische Sozialforschung. Weinheim: Beltz.

Meyer, H. (2006). Unterrichtsmethoden. Praxisband. Frankfurt a. M.: Scriptor.

Morgan, D. L. (1998). Planning Focus Groups. Thousand Oaks, London, New Delhi: Sage.

Morgan, D. L. (1997). Focus Groups as Qualitative Research. Thousand Oaks, London, New Delhi: Sage.

Nentwig, P., Demuth, R., Parchmann, I., Gräsel, C. \& Ralle, B. (2007). Chemie im Kontext: Situating learning in relevant contexts while systematically developing basic chemical concepts. Journal of Chemical Education, 84 (9), 1439-1444.

Niedersächsisches Kultusministerium (2008). Kerncurriculum für das Gymnasium gymnasiale Oberstufe. Biologie. Arbeitsfassung November 2008. Online verfügbar unter: http://nline.nibis.de/cuvo/forum/upload/public/moderator/K266mode-microsoft word---kc_biologie_go_arbeitsfassung_nov_2008.pdf (abgerufen am 15. Dezember 2008).

Niedersächsisches Kultusministerium (2007). Kerncurriculum für das Gymnasium. Schuljahrgänge 5-10. Naturwissenschaften, Biologie. Online verfügbar unter: http://www.nibis.de/nli1/gohrgs/kerncurricula_nibis/kc_2007/kc07_gym/kc_gym_nw s_07_nib.pdf(abgerufen am 15. Dezember 2008).

Niedersächsisches Kultusministerium (2006). Regionale Umweltbildungszentren (RUZ). Online verfügbar unter: http://www.mk.niedersachsen.de/master/C26716_N12387 _L20_D0_I579.html\# (abgerufen am 15. Dezember 2008).

Okun, M. \& Sloane, E. (2002). Application of planned behavior theory to predicting volunteer enrollment by college students in a campus-based program. Social Behavior and Personality, 30 (3), 243-250. 
Ostermeier, C., Prenzel, M. \& Duit, R. (2009). Improving Science and Mathematics Instruction: The SINUS Project as an example for reform as teacher professional development. International Journal of Science Education.

Papoulia-Tzelepi, P. (1996). Collaborative, Formative Evaluation in Teaching Practice: a road to reflexity. European Journal of Teacher Education, 19 (3), 251-260.

Parchmann, I., Gräsel, C., Baer, A., Nentwig, P., Demuth, R. \& Ralle, B. (2006). Chemie im Kontext - A symbiotic implementation of a context-based teaching and learning approach. International Journal of Science Education, 28 (9), 1041-1062.

Ramsey, J. (1989). A Technique for Analyzing Environmental Issues. Journal of Environmental Education, 57 (3), 26-30.

Rauch, F., Steiner, R. \& Streissler, A. (2008). Kompetenzen für Bildung für Nachhaltige Entwicklung von Lehrpersonen: Entwurf für ein Rahmenkonzept. In I. Bormann \& G. de Haan (Hrsg.), Kompetenzen der Bildung für Nachhaltige Entwicklung: Operationalisierung, Messung, Rahmenbedingungen, Befunde. Wiesbaden: VS Verlag, 141-157.

Reinmann-Rothmeier, G. \& Mandl, H. (1999). Implementation konstruktivistischer Lernumgebungen - Revolutionärer Wandel oder evolutionäre Veränderung? In H.-E. Renk (Hrsg.), Lernen und Leben aus der Welt im Kopf. Konstruktivismus in der Schule, Neuwied: Luchterland.

Reinmann-Rothmeier, G. \& Mandl, H. (1998). Wenn kreative Ansätze versanden: Implementation als verkannte Aufgabe. Forschungsbericht Nr. 87. München: Ludwig-Maximilians-Universität München.

Retzlaff-Fürst, C. (2005). Bodenlebewesen - nur hässliche Lebensformen der Biovielfalt? Schülervorstellungen zur Ästhetik von Kellerassel, Hundertfüßer und Schwarze Wegschnecke. In R. Klee, H. Bayrhuber \& A. Sandmann (Hrsg.), Lehrund Lernforschung in der Biologiedidaktik.. Innsbruck: Studienverlag, 101-113.

Rickinson, M. (2006). Researching and understanding environmental learning: hopes for the next 10 years. Environmental Education Research, 12 (3\&4), 445-457.

Rickinson, M. (2001). Learners and learning in environmental education: a critical review of the evidence. Environmental Education Research, 7 (3), 207-320. 
Scherzinger, W. (1997). Tun oder unterlassen? Aspekte des Prozessschutzes und Bedeutung des "Nichts-Tuns" im Naturschutz. In Bayerische Akademie für Naturschutz und Landschaftspflege (Hrsg.), Wildnis - ein neues Leitbild!? Möglichkeiten und Grenzen ungestörter Naturentwicklung in Mitteleuropa, München: Bayerische Akademie für Naturschutz und Landschaftspflege, 31-44.

Schönfelder, S. (2005): Vorstellungen zu Wildnis. In H. Vogt, D. Krüger, S. Bögeholz \& M. Herget (Hrsg.), Erkenntnisweg Biologiedidaktik. Kassel: vdbiol, 21-34.

Schratz, M. (2003). Qualität sichern. Schulprogramme entwickeln. Seelze: Kallmeyersche Verlagsbuchhandlung.

Seipel, C. \& Rieker, P. (2003). Integrative Sozialforschung. Konzepte und Methoden der qualitativen und quantitativen empirischen Forschung. Weinheim: Juventa.

Stewart, D. W. , Shamdasani, P. N. \& Rook, D. W. (2007). Focus Groups. Theory and Practice. Thousand Oaks, London, New Delhi: Sage.

Stiel, K. (2007). Subjektive Überzeugungen bei Umweltbildner(inne)n eines Regionalen Umweltbildungszentrums in Bezug auf ihr neues Leitbild zur Biodiversitätsbildung. Examensarbeit an der Georg-August-Universität Göttingen.

Townsend, C. R., Harper, J. L. \& Begon, M. E. (2003). Ökologie. Berlin u. a.: Springer.

Tschirigi, J. E. (1980). Sensible reasoning: A hypothesis about hypotheses. Child Development, 51, 1-10.

Tuxill, J. (2000). The Biodiversity that People Made. World Watch, 25-35.

Von Kardorff, E. (2008). Qualitative Evaluationsforschung. In U. Flick, E. v. Kardorff \& I. Steinke (Hrsg.), Qualitative Forschung. Ein Handbuch. Reinbek: Rowohlt.

Weinert, F. E. (2001). Concept of Competence: A Conceptual Clarification. In D. S. Rychen, L. H. Salganik (Eds.), Defining and Selecting Key Competencies. Seattle, Toronto, Bern, Göttingen: Hogrefe \& Huber, 45-65.

Wilson, J. R. \& Monroe, M. C. (2005). Biodiversity Curriculum that supports Education Reform. Applied Environmental Education \& Communication, 4 (2), 125-138. 
World Commission on Environment and Development (WCED) (1987). Our Common

Future. Available online at: www.are.admin.ch/are/en/Nachhaltig/international-uno /unterseite02330/ (accessed on 8 August 2008).

Wottawa, H. \& Thierau, H. (2003). Lehrbuch Evaluation. Bern, Göttingen, Toronto, Seattle: Verlag Hans Huber.

World Wide Fund for Nature (WWF) (2007). Neobiota: Aliens im Tier- und Pflanzenreich. Vom Menschen eingeführten Arten verändern die heimische Flora und Fauna. Available online at: http://www.wwf.de/themen/artenschutz/biologischevielfalt/neobiota/ (accessed on 8 August 2008). 


\section{Anhang}

\section{Aufbereitungs- und Auswertungsleitfaden für problemzentrierte}

\section{Einzelinterviews und Fokusgruppen}

\section{Aufbereitung}

Die Tonaufzeichnungen der sprachlichen Äußerungen der Interviewten werden in eine lesbare Form überführt und auf die relevanten Aussagen reduziert (Gropengießer, 2001).

\section{Transkribieren}

Das Interview bzw. die Fokusgruppe wird vollständig und wörtlich transkribiert (verändert nach Mayring, 2002). Das heißt, die gesprochene Sprache wird verschriftet. Dabei werden Dialektfärbungen hochdeutsch transkribiert. Folgende Transkriptionsregeln (Abbildung 12) werden berücksichtigt:

- vollständige und wörtliche Transkription

- Dialektfärbungen hochdeutsch transkribieren

\begin{tabular}{|l|l|}
\hline Sprachliche Zeichen & Bedeutung \\
\hline I & Interviewer(in) \\
\hline UB & Anonymisierte Bezeichnung der Interviewpartner(innen) \\
\hline äh, ähm & zustimmend \\
\hline$(\ldots)$ & überlegend, unsicher \\
& $\begin{array}{l}\text { Kommentare zu nicht sprachlichen Zugängen wie Gestik, } \\
\text { Mimik werden in geschweifte Klammern gesetzt und in } \\
\text { Schriftgröße 10 angeführt. } \\
\text { Bsp.: (Räuspern), (Stirnrunzeln), (Lachen) }\end{array}$ \\
\hline$? ? ?$ & akustisch unverständliche Passagen \\
\hline$(-)$ & Pause \\
\hline$(---)$ & längere Pause (ab 10 sec.) \\
\hline Betonung & Auffällig betonte Äußerungen werden kursiv gesetzt \\
\hline
\end{tabular}

Abbildung 12. Transkriptionsregeln (verändert nach Mayring, 2002) 
Die transkribierten Aussagen werden durch Zeilennummern gekennzeichnet, um folgende Aufbereitungs- und Auswertungsergebnisse mit den Originalaussagen überprüfend vergleichen zu können.

\section{Redigieren (nur Interview)}

In einem weiteren Aufbereitungsschritt wird das transkribierte Interviewmaterial redigiert. Ziel ist es, das Datenmaterial in eine angemessen lesbare Form zu überführen und auf bedeutsame Aussagen zu reduzieren. Folgende Regeln (verändert nach Gropengießer, 2001) sind hierfür zu beachten:

1. Bedeutungstragende Aussagen werden selegiert. Unter einer bedeutungstragenden Aussage wird der jeweilige Redeabsatz des Interviewten verstanden.

2. Aussagen werden als ganze Sätze formuliert und grammatisch geglättet. Dabei bleibt die Sprache der Interviewten insbesondere sprachliche Mittel erhalten.

3. Füllwörter, Füllsätze und Füllsel („,mh“, ,ähm“) sowie unmittelbare Wiederholungen und nicht inhaltstragende Wörter wie „tja“ und „ne“ werden ausgelassen. Variationen einzelner Wörter sowie Präzisierungen und verworfene Selbstkorrekturen werden beibehalten und in Klammern (...) weitergeführt. Wenn zwischen zwei Pausen ein „ähm“ steht, bleiben die Pausensymbole erhalten.

4. Die Aussagen der Interviewten werden so ergänzt, dass sie auch außerhalb des Gesprächskontextes (Wechselspiel von Fragen und Antworten) verständlich sind. Dabei werden die Frageinhalte des Interviewers / der Interviewerin in eckigen Klammern [...] den Aussagen der Interviewten hinzugefügt.

5. Das Redigieren des Datenmaterials wird durch eine weitere Person überprüft. Hierfür werden die Transkriptaussagen mit den redigierten Abschnitten verglichen.

(Anmerkung: Redigieren kann dazu beitragen, das Leseverständnis der Aussagen von Interviewpartner(inne)n zu verbessern. Grundsätzlich ist dieser Schritt jedoch nicht zwingend notwendig (vgl. Mayring, 2002, 2008). Im Rahmen einer Auswertung der Fokusgruppen wurde auf diesen Datenaufbereitungsschritt verzichtet. Diese Entscheidung ist bedingt durch die großen Datenmengen, die in einem Gruppeninterview, wie einer Fokusgruppe, anfallen (Bryman, 2004). Der Arbeits- und Zeitaufwand für das Redigieren des Datenmaterials wäre im Verhältnis zum Arbeits- und Zeitaufwand der Datenauswertung nicht gerechtfertigt gewesen.) 


\section{Auswertung}

Die Auswertung des aufbereiteten Datenmaterials erfolgt in Anlehnung an die Qualitative Inhaltsanalyse nach Mayring (2008) und Gropengießer (2001). Die spezifische Auswertungsform wird als typisierende Strukturierung bezeichnet (vgl. Mayring, 2008). Folgende Schritte werden bei der Auswertung berücksichtigt:

\section{Erstellung eines Kategoriensystems (MAXqda 2007)}

Kategorien werden zunächst deduktiv erstellt und im Zuge der Zuordnung von Textstellen an die Kategorien induktiv ergänzt. Jede Kategorie wird durch „Memos“ benannt, definiert und durch ein Ankerbeispiel aus dem Datenmaterial ergänzt. Zusätzlich werden für jede Kategorie Ausschlussregeln zur Abgrenzung von anderen Kategorien formuliert. Das Kategoriensystem wird gemeinsam von mindestens zwei Personen erstellt. Eine Zuordnung von Textstellen (Transkriptaussagen bzw. redigierte Aussagen der Interviews) erfolgt ebenfalls in Zusammenarbeit von mindestens zwei Personen.

\section{Zusammenfassung}

Innerhalb der Kategorien werden die zugeordneten Textstellen zusammengefasst. Dabei werden die Zeilennummern der Originalaussagen stets mitgeführt.

\section{Explikation (nur Interview)}

Es wird zusätzliches Material herangetragen, um eine nicht ausreichend erklärbare Textstelle zu deuten. Dabei wird eine enge von einer weiten Kontextanalyse unterschieden. Bei der engen Kontextanalyse handelt es sich um Erläuterungen aus dem direkten Textumfeld. Hingegen wird bei einer weiten Kontextanalyse Material hinzugezogen, das über den Text hinausgeht, wie z. B. Lexika.

In einem weiteren Explikationsschritt werden sprachliche Mittel (Metaphern, Metonymien usw.) ausgelegt. Zudem werden Widersprüche und offensichtliche Probleme im Verständnis herausgestellt. Alle Explikationen werden von einer zweiten Person kritisch überprüft. 
Gruppenmitglieder selbst geklärt. Sprachliche Mittel wurden kaum verwendet. Widersprüche und Probleme im Verständnis wurden direkt in der Fokusgruppe angesprochen und geklärt.)

\section{Strukturierung}

Kategorisierte und ggf. explizierte Textstellen bilden die Grundlage für einen Strukturierungsprozess. Das Datenmaterial wird Kategorien übergreifend nach theoretischem Interesse (z.B. Theory of Planned Behavior; Ajzen, 2005, 2008) geordnet (strukturiert) und interpretiert. Die Ergebnisse werden anschließend für eine Berichterstattung aufbereitet und im Rahmen einer formativen Evaluation dazu verwendet, um Optimierungsmaßnahmen abzuleiten (z. B. Kuckartz et al., 2008). 


\section{Datennachweis}

Das erhobene Datenmaterial der Evaluationsstudie liegt in Form von Transkripten der Fokusgruppen und Einzelinterviews sowie Beobachtungsprotokollen vor.

\section{Zu Teilstudie 1}

Interviewleitfaden der Fokusgruppe 1

$>$ Transkript der Fokusgruppe 1

Beobachtungsprotokolle der Module 1, 2, 3 und 4 (jeweils 2 Protokolle)

\section{Zu Teilstudie 2}

Interviewleitfaden für Einzelinterviews

Transkripte der Interviewpartner(innen) UB1, UB2, UB3 und UB4

\section{Zu Teilstudie 3}

Interviewleitfaden der Fokusgruppe 2

Transkript der Fokusgruppe 2

Die Originaldaten werden nicht veröffentlicht. Sie liegen in der wissenschaftlichen Einrichtung, in welcher die Studie durchgeführt wurde:

Georg-August-Universität Göttingen

Didaktik der Biologie

Waldweg 26

37073 Göttingen 